\title{
SIGNIFICANCE OF SELECTIVE PREDATION AND DEVELOPMENT OF PREY PROTECTION MEASURES FOR JUVENILE SALMONIDS IN THE COLUMBIA AND SNAKE RIVER RESERVOIRS
}

\author{
ANNUAL REPORT \\ February 1992-February 1993
}

Prepared by:

Thomas P. Poe

Dena M. Gadomski

U.S. Fish and Wildlife Service National Fishery Research Center Columbia River Field Station

Prepared for:

U.S. Department of Energy

Bonneville Power Administration

Division of Fish and Wildlife

P.O. Box 3621

Portland, OR 97283-3621

Project Number 82-003

Contract Number DE-AI79-88BP91964

SEPTEMBER 1994 
TABLE OF CONTENTS

TABLE OF CONTENTS. . . . . . . . . . . . . . . . . . . . .

EXECUTIVE SUMMARY. . . . . . . . . . . . . . . . . . . . 3

SELECTIVE PREDATION

Report 1 (Abstract only) - Estimatins nrev mortality when predators are selective: Feeding by northern squawfish on live and dead juvenile salmonids in the Bonneville Dam tailrace (Columbia River) by James $\mathrm{H}$. Petersen, Dena M. Gadomski, and Thomas P. Poe. . . . . .5

Report 2 (Abstract only) - Vulnerability to predation and physiological stress responses of iuvenile chinook salmon exposed to multiple acute disturbances by M.G. Mesa . . . . . . . . . . . . . . . . . 7

Report 3 - The role of bacterial kidnev disease in the vulnerability of iuvenile chinook salmon to predation

by Matthew G. Mesa. • . . . . . . . . . • . . . . . . 9

PREY PROTECTION

Report 4 (Abstract only) - Prolonsed swimmins Performance of northern squawfish: Can water velocity be used to reduce predation on iuvenile salmonids at Columbia River dams? by Matthew G. Mesa and Todd M. Olson. . . .35

Report 5 - Movements and distribution of radio-tagged

northern sauawfish near The Dalles Dam by R.S.Shively, S.R. Hirtzel, L.L. Mann, T.L. McGuire, and

G. Holmberg . . . . . . . . . . . . . . . . . . . . . . . .

Report 6 - Movement, distribution, and behavior of

iuvenile salmonids passing throush Columbia and

Snake river dams, 1992 by David A. Clugston, and

Carl B. Schreck. . . . . . . . . . . . . 75

Report 7 - Movements of northern sauawfish near Lower

Granite Dam in the spring of 1992 by D.J. Isaak and

T.C. Bjornn. . . . . . . . . . . . . . . 106 


\section{EXECUTIVE SUMMARY}

This document is the 1992 annual report of progress for the Bonneville Power Administration (BPA) research Project No. 82-003 conducted by the U.S. Fish and Wildlife Service (FWS), the Oregon Cooperative Fishery Research Unit (OCFRU), and the Idaho Cooperative Fish and Wildlife Research Unit (ICFWRU). Our approach was to present the progress achieved during 1992 in a series of separate reports for each major project task. Each report is prepared in the format of a scientific paper and is able to stand alone, whatever the state of progress or completion. Reports 1, 2, and 4 consist of the Abstract only (journal papers were submitted in lieu of reports).

This project has two major goals. One is to understand the significance of selective predation and prey vulnerability by determining if substandard juvenile salmonids (dead, injured, stressed, diseased, or naive) are more vulnerable to predation by northern squawfish, Ptvchocheilus oreqonensis, than standard or normal juvenile salmonids. The second goal is to develop and test prey protection measures to control predation on juvenile salmonids by reducing predator-smolt encounters or predator capture efficiency.

The following point summary gives the major results for 1992 on each of the major project objectives and tasks:

(1) We conducted field experiments in the Bonneville Dam tailrace (Columbia River) to compare predation rates by northern squawfish on live and dead juvenile salmonids. Known numbers of coded-wire tagged live and dead chinook salmon were released into the tailrace on six nights, northern squawfish were collected after each release, and predator stomach contents were examined for prey tags. When 50\% of salmon released were dead, northern squawfish consumed $60 \%$ dead salmon and large northern squawfish (>300 mm fork length) captured relatively more dead salmon than small predators. When $10 \%$ of salmon released were dead, 22\% of the tags in predator's guts were from dead salmon. These results corroborate laboratory studies and suggest that established salmonid losses to northern squawfish below dams should be re-calculated.

(2) When equal numbers of stressed and unstressed juvenile spring chinook salmon were exposed to predation by northern squawfish for various lengths of time (l-24 h), only fish receiving an agitation stress and exposed to predation for $1 \mathrm{~h}$ showed a significant difference in their vulnerability to predation. The results suggest that various factors which may stress smolts (i.e. handling, crowding, or dam passage) may increase vulnerability to predators. The results also suggest that there are several aspects to consider in the conduct and interpretation of predation tests designed to assess the effects of stress. Observed responses are likely polymorphic and dependent on the stressor itself, the 
predator-prey system being studied, and experimental protocols.

(3) An immersion challenge method was successfully used to infect juvenile spring chinook salmon with bacterial kidney disease (BKD) to examine the vulnerability to predation of smolts with differing BKD profiles. Results thus far indicate that fish infected with only low to moderate, sub-clinical levels of BKD may be significantly more vulnerable to predators.

(4) We determined the prolonged swimming performance of two sizes of northern squawfish at 12 and $18^{\circ} \mathrm{C}$. Swimming performance was positively related to fish size and water temperature. For medium size fish $(30-39 \mathrm{~cm}$ fork length), the velocity at which $50 \%$ of the fish fatigued (FV50) ranged from 95-105 cm/s and maximum performance from 107-112 cm/s. For large fish $(40-49 \mathrm{~cm})$, FV50 ranged from 100-114 cm/s and maximum performance from 118-135 cm/s. Our results suggest that high water velocity areas may be used to exclude or reduce predation by northern squawfish around juvenile salmonid bypass outlets at Columbia River dams, especially during spring and early summer.

(5) Movements and distribution of 93 radio-tagged northern squawfish were monitored in The Dalles Dam tailrace to determine how they responded to changes in river flow, dam operations, and juvenile salmonid emigration patterns. Distributions of northern squawfish were significantly different during various modes of operation of the spilling and ice-trash sluiceway in the spring but a high rate of transmitter failure compromised overall results.

(6) OCFRU - Subcontract Steelhead and spring chinook smolts were implanted with radio tags, released at two potential bypass outfall sites in The Dalles Dam tailrace, and tracked to determine which release site would disperse smolts most quickly and avoid areas of high predation risk. Groups of steelhead smolts released from the more upstream location dispersed significantly slower than smolts released from a downstream site (at least for the first 30 minutes following release).

(7) ICFWRU - Subcontract Movements and distribution of 77 radio-tagged northern squawfish were monitored in the tailrace area of Lower Granite Dam to determine how they responded to project operations and smolt migration. Results indicated that squawfish spent the majority of their time in a slackwater area near the north shore fish ladder entrance with occasional movements into the turbine discharge areas. Early transmitter failure also limited data collection. 


\title{
Report 1
}

\section{Estimating prey mortality when predators are selective: Feeding by northern squawfish on live and dead juvenile salmonids in the Bonneville Dam tailrace (Columbia River)}

James H. Petersen, Dena M. Gadomski, and Thomas P. Poe

U.S. Fish and Wildlife Service, National Fisheries Research Center-Seattle, Columbia River Field Station

\begin{abstract}
Juvenile salmonids (oncorhvnchus spp.) that have been killed or injured during dam passage may be highly vulnerable or preferred prey of predators that aggregate below dams. Salmonid loss due to predation will be overestimated using gut content analysis if some prey were dead or moribund when consumed. Field experiments were conducted in the Bonneville Dam tailrace (Columbia River) to compare capture rates by northern squawfish (Ptvchocheilus oresonensis) on live and dead juvenile salmonids. Known numbers of coded-wire-tagged live and dead chinook salmon 10 . tshawvtscha) were released into the tailrace on six nights, northern squawfish were collected after each release, and predator gut contents were examined for tags. When 50\% of salmon released were dead, northern squawfish consumed 60\% dead salmon: large northern squawfish (>300 mm- fork length) captured dead salmon at a higher rate than small northern squawfish. When $10 \%$
\end{abstract}


of salmon released were dead, $22 \%$ of the tags found in predators were from dead salmon. These results indicate how the selective feeding behavior of predators and the availability of prey of various conditions may be important considerations when estimating the impact of predation on a prey population. 
Report 2 Vulnerability to Predation and Physiological Stress Responses of
Juvenile Chinook Salmon Exposed to Multiple Acute Disturbances.

Mesa, M. G.

U.S. Fish and Wildlife Service, National Fisheries Research Center-Seattle, Columbia River Field Station

\begin{abstract}
I examined vulnerability to predation and physiological stress responses of juvenile spring chinook salmon (Oncorhvnchus tshawytscha) subjected to two multiple acute disturbances-handling and physical agitation. Both stressors elicited lethargic behavior in the fish, but agitation, which was designed to simulate a chaotic, physically demanding environment, also caused disorientation and occasional injury. When equal numbers of stressed and unstressed fish were exposed to predation by northern squawfish (Ptvchocheilus oresonensis) for up to $1 \mathrm{~h}$, stressed fish showed a significant increase in vulnerability to predation, but this effect was not evident during longer exposures. Stressed fish had significantly elevated levels of plasma cortisol, glucose, and lactate before their release to predators. Based on the magnitude of the maximum change and recovery times, the physiological responses of fish receiving either multiple handlings or agitations were similar and
\end{abstract}


sometimes cumulative. Concentrations of plasma cortisol, glucose, and lactate in fish receiving multiple disturbances were significantly elevated beyond levels observed in fish experiencing only a single disturbance, and they returned to prestress levels by $6-24 \mathrm{~h}$ after the final stress. My results indicate that physical stress-induced deficits in predator avoidance are short lived and not necessarily correlated temporally with clinical indicators of stress. 
Matthew G Mesa

U. S. Fi sh and Vill dl ife Service Nati onal Fi sheri es Research Center-Seattle Col unbi a Ri ver Fi el d Station Cook, Whshi ngt on 98605, USA

\section{ABSTRACT}

I used an i mersi on chal l enge nethod to i nf ect j uveni l e spring chi nook sal non Oncorhvnchus tshauvtscha wi th Reni bacteri um sal moni narum the causati ve agent of bacteri al ki dney di sease ( $B K D)$, to examine the vul nerability to predation of fish with differing BKD profiles. The i mersi on chal l enge was successful, on average, of producing a I ow to moderate inf ecti on (determined by enzyne- I i nked i munosor bent assay) of $\underline{R}$. sal noni nar um i $n$ treatnent fish. At sel ected interval s during the 16 week chal I enge, treat ment fi sh al ways had si gni fi cantl y hi gher i nf ecti on I evel s than unchal I enged control fi sh, whi ch mai nt ai ned very I ow or negative inf ections throughout the experi ment. When equal numbers of BKD chal I enged and control fi sh were subj ected 
to predati on by northern squanf i sh Ptvchochei I us or eqonensi s for $24 \mathrm{~h}$, BKD chal l enged fi sh were eaten in si gni fi cantl y greater numbers than controls. On average, $65 \%$ of the total $\mathrm{fish}$ consuned were of the treatnent group. My resul ts indicate that fi sh infected wi th onl y l ow to noderate, sub-cli ni cal l evel s of R. Sal noni narum may be si gni fi cantl y nore vul nerable to predati on, thus provi ding sone evi dence of the functi onal, autecol ogi cal si gnificance of BKD and the role it plays in affecting the survival of fish in the wild.

\section{INTRODUCTION}

Bacteri al ki dney di sease ( $B K D)$, caused by Reni bacteri um sal moni narum has I ong been a si gni fi cant contri but or to nortal ity of $\mathbf{j}$ uveni le sal noni ds in hatcheri es in the Col unbi a Ri ver basi $n$. The di sease is not onl y consi dered to be a maj or obstacl e to the successf ul cul ture of sal monids, but is preval ent in and presumbly has sone i mpact on wi I popul ati ons (EI I is et al. 1978; Mtchum et al. 1979; Paterson et al. 1979; El li ott and Pascho 1992; Sanders et al. 1992). The di sease causes chroni $c$ nortal $\mathrm{i}$ ty duri ng hatchery resi dency of $\mathrm{j}$ uveni $\mathrm{I} e$ sal moni ds and evi dence i ndi cates nortal i ty may be exacerbated when fi sh enter sal t water (El I is et al. 1978; Paterson et al. 1979; Fryer and Sanders 1981; Banner et al. 1983). Control of BKD is di ffi cul t 
to achi eve and, because I arge gaps persi st i n our know edge of the i nf ecti on (El li ott et al. 1989), thi s di sease wi I conti nue to recei ve a consi derable anount of research i nterest.

Mbst research on BKD has, understandabl $y$, focused on the et i ol ogy, epi demi ol ogy, pathogeni ci ty, and control of the di sease. Thus, Iittle is known about the effects BKD may have on sel ected aspects of $\mathrm{fi}$ sh perfornance capaci ty (sense Schreck 1981), such as predat or avoi dance ability, swi ming perfornance, or snol tification. Because the i mpact of BKD on migrating hatchery and wi I fi sh has been diffi cult to eval uate (Sanders et al . 1992), examining the effects of BKD on ecol ogi cal I y rel evant perf or nance characteri stics should el uci date the functi onal si gni ficance of BKD and the role it plays in the survival of fish in the wild.

The recent devel opment of nore sensi ti ve and quant i tati ve detecti on methods for BKD, such as the enzyne-li nked i munosor bent assay (ELI SA; Pascho and Mul cahy 1987; Turaga et al . 1987) has al I oned researchers to nore accuratel y det er mi ne the preval ence and I evel s of BKD in sal moni d popul ati ons (Pascho et al . 1987). Consequent l y, fi sh have been cl assi fi ed as havi ng I ow moderate, and hi gh i nf ecti on I evel s based on ELI SA resul ts ( Pascho et al. 1991). Thi s i mpl i es that di ffering i nf ection I evel s nay have sone adapti ve si gni fi cance, but thus far such 
I evel s appear to be of cli ni cal significance only. Thi s study represents an effort to ascri be sone autecol ogi cal si gni fi cance to BKD by examining the vul nerabi I ity to predati on of $j$ uveni l e spring chi nook sal mon with differing BKD profiles.

\section{METHODS}

J uveni I e spring chi nook sal non (average fork I ength $\pm \mathrm{SE}$, 84.84 $\pm 1.34 \mathrm{~mm} ; \underline{N}=100$ ) were obtai ned on 21 Apri I 1992 from Enti at Nati onal Fi sh Hatchery (Wtshi ngt on). A I fi sh were of fspring fromadul ts with a negati ve or I ow i nf ecti on I evel of BKD as determi ned by ELI SA segregati on (Pascho et al . 1991). Fi sh were transported by truck in a I arge al umi num tank wi th aerated water at about $10^{\circ} \mathrm{C}$. Transport ti me was about $6 \mathrm{~h}$ and water temperature fl uctuated Iittle. Upon arrival at our I aboratory, about $750 \mathrm{fi}$ sh were $\mathrm{pl}$ aced in each of four $1.5 \mathrm{~m}$ ci rcul ar tanks recei vi ng $10 \pm 1^{\circ} \mathrm{C}$ uel I water. Fi sh in tuo adj acent tanks were cl assi fied as controls whereas fish in the ot her t uo tanks uere quaranti ned and cl assi fi ed as treat ment groups. Because of di fferences in tank depth, densi ti es in the f our tanks vari ed sl i ghtl y: Tank 1 (Control) = $9.3 \mathrm{~g} / \mathrm{L}$; Tank 2 (Control) $=9.5 \mathrm{~g} / \mathrm{L} ;$ Tank 1 (Treat ment) $=7.6 \mathrm{~g} / \mathrm{L}$; and Tank 2

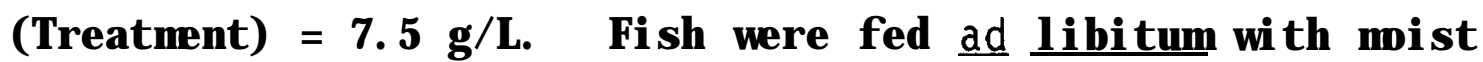
pel I ets and kept under an ambi ent photoperi od. A I control fi sh were marked by cli ppi ng thei $r$ adi pose fin. 
On 30 April 1992, treat nent fijsh were subjected to an i mersi on chal l enge of approxi matell y $1.5 \times 10^{6}$ bacteri a/ $\mathrm{ml}$ water. A broth cul ture of $\underline{R}$. sal moni narum was made and quantifi ed by personnel at the Nati onal Fi sheri es Research Center-Seattl e. At $2200 \mathrm{~h}$, the water I evel in al I four tanks was standardi zed to 500 L by i nserting new standpi pes. I nf I ow water was shut of $f$ and oxygen from tanks and ai $r$ pumps was added to each tank; water temperat ure uas $10.5^{\circ} \mathrm{C}$. The tuo treatment tanks each recei ved 1 L of broth cul ture contai ni ng about $8 \times 10^{\prime \prime}$ bacteria/ $\mathrm{m}$. Control tanks each recei ved $1 \mathrm{~L}$ of pept one-sal i ne. The I i qui d uas poured throughout the tank and the chal I enge conti nued for 24 h.

To check on the viability of bacteria in the chal lenge tanks and to provi de a secondary esti mate of the dose, water sampl es uere taken from each tank at $1 \mathrm{~h}$ after the start and $1 \mathrm{~h}$ before the end of the chal l enge. Usi ng $250 \mathrm{~mL}$ gl ass beakers, we sampl ed $1 \mathrm{~L}$ of water from each tank and poured it into sterile, plastic bottles. Fromthis, we transferred ca. $10 \mathrm{~mL}$ i nto a sterile test t ube for cul ture on sel ecti ve medi a. We added $0.1 \mathrm{~g}$ thi merosal as a preservative to the remai ni ng uater sampl es and froze them for fut ure anal ysi s.

A I $10 \mathrm{~mL}$ water sampl es were cul tured on sel ecti ve KDM agar nedi um (Austi $n$ et al . 1983). Each sampl e was di I uted 1:100 and 
$1: 1000$ w th peptone-sal i ne and cul tured in tri pl i cate. Cul tures were made by evenl y di spersing $100 \mu \mathrm{L}$ of sampl e over the agar surface with a gl ass spreader. Al plates were seal ed with parafi I mand placed in the ref rigerator at $4^{\circ} \mathrm{C}$. On 4 Myy 1992 , al I pl ates were transferred on i ce to the Oregon State Uni versity M crobi ol ogy Department and i ncubated at $17^{\circ} \mathrm{C}$. Cul tures were i nspected for grouth of col oni es characteristic of $\underline{R}$. sal noni nar um after 4 weeks and for several ueeks thereafter. The chal I enge ended on 1 Myy 1992 at $2200 \mathrm{~h}$. The ori gi nal st andpi pes were repl aced, water turned on, and al I mi scel I aneous equi pment renoved and sterilized. Wter temperatures at the end of the chal I enge ranged from 12.0 to $12.4^{\circ} \mathrm{C}$. Fi sh were mai ntai ned as described above (at $12-13^{\circ} \mathrm{C}$ ) for a peri od of $100 \mathrm{~d}$.

To monitor the progressi on of the di sease during the $100 \mathrm{~d}$ i ncubati on and to esti mate the ti ne when predation trials should

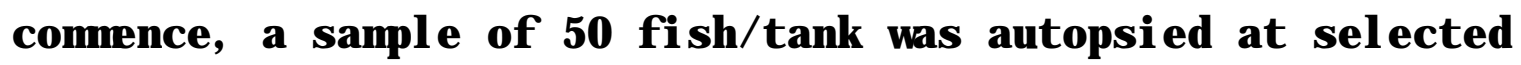
i nterval s for anal ysi s of whol e ki dneys by ELI SA Sampl es vere taken at 2, 6, 10,12,13, 14 and 15 weeks after the chal lenge ended. Tuenty $\mathrm{f} i$ ve $\mathrm{fi}$ sh from each tank were rapi dl $\mathrm{y}$ renoved by di p netti ng and pl aced i $n$ a l ethal dose ( $200 \mathrm{ng} / \mathrm{L}$ ) of tricai ne. After recording the I ength and wei ght of each fi sh, the ki dney was renoved aseptical Iy and honogenized. A I sampl es were frozen at $-80^{\circ} \mathrm{C}$ for future anal ysi s by ELISA as described by Pascho and 
Mul cahy ( 1987) and nodi fi ed by El I i ott and Pascho (1991). Because there were no di fferences in average ELI SA opti cal densi ti es bet ueen repl i cate tanks wi thi $n$ each sampl i ng i nterval (ANOVA, $\underline{P}>0.05$ ), data nere pool ed for anal ysi s. Vithi $n$ each sampl i ng i nterval , I then compared the mean ELI SA opti cal densi ti es bet ween control and treat ment fi sh using a t uo-sample t-test and pl otted the frequency di stri buti on of ELI SA val ues. Mortal ities during the chal lenge were tal I i ed and someti mes aut opsi ed, and I compared the mean I engths of fi sh in the tuo groups wi thi $n$ each sampl ing i nterval usi ng a two sampl e t-test. Predati on experi ment

The predati on experi ment was composed of several repl i cate tri al s, al I conducted i n a I arge, fllowing water raceway (descri bed by Petersen et al 1 1990). Si x northern squaufi sh (ca. fork I ength $>40 \mathrm{~cm}$ ), capt ured fromthe Col unbi a Ri ver by el ectrof i shi ng, were st ocked in the raceway on $20 \mathrm{~J}$ ul y 1992. Whter temperature was $16 \pm 1^{\circ} \mathrm{C}$ and $\mathrm{I}$ ighti ng control $\mathrm{I}$ ed by ti ners si mul ated an anbi ent photoperi od wi th a gradual i ntensi ty dusk and dawn. Predators were accl i nated for at l east tho weeks and fed $20 \mathrm{j}$ uveni I e spri ng chi nook sal mon every $24 \mathrm{~h}$. The number of sal mon eaten i $\mathbf{n} 24 \mathrm{~h}$ was noni tored and new prey added dai I y to bring the prey ration up to $20 \mathrm{fish}$.

To begi $n$ the first trial, predators uere deprived of food 
for $24 \mathrm{~h}$. At 0800 on the norni ng fol l owing starvation, 12 or 13 fish from each prey hol di ng tank (i.e. 25 from each treatment) were rapi dl y transferred into 19 L buckets filled with water and poured i nto the upstream end of the raceway. Predati on was al I owed to conti nue for $24 \mathrm{~h}$. At the end of a tri al, al I survi vors were netted, i dent i fi ed, neasured, and thei $r$ ki dneys exci sed for anal ysi s by ELI SA Tri al s uere conducted on consecuti ve days from 3 August to 20 August 1992; this was during neeks 13, 14, and 15 after the BKD chal I enge and resul ted i $n$ a total of 18 repl i cate trials. The data nere subjected to a het erogenei ty chi-square anal ysi s to determine if the repl i cates were honogenous ( Sokal and Rohl f 1981). Chi-square goodness- of fit tests were then used on pool ed data to determi ne if feeding uas random (i . e. 50: 50)..

\section{RESULTS}

The i mersi on chal llenge was successf ul, on average, of produci ng a noderate i nf ecti on of $\underline{R}$. sal moni narum i $n$ treat ment fi sh from about neek 10 on (Fi gure 1). Because of unexpected techni cal difficulti es, I uas unable to anal yze sampl es from week 15; al so, data from the water sampl e cul tures were not avai I able for this report. Mean ELISA optical densi ties of fish in repl i cate tanks never di ffered, except for week 12 i n treat ment fish. Using pool ed data, the nean ELISA optical densities of 
treat ment fi sh were si gni fi cantl y $(p<0.001)$ hi gher than control fi sh for al I sampling intervals. Control fi sh showed ei ther very I ow or negati ve inf ecti on I evel s for the durati on of the experi nent. For chal l enged fi sh, the frequency di stri buti ons of i nf ecti on l evel s were skewed to the l ef $t$, i rrespecti ve of ti ne (Fi gure 2). A though vari ances vere rel ati vel y hi gh, nost fi sh recei ving the chal I enge had ELI SA val ues of about 0.6 and bel ows thus corresponding to a l ow to moderate infection profile. Mrtaliti es were I ow in both control tanks, except during weeks 4 through 6 when a temporary water qual ity probl em was present (Figure 3). In the treat ment tanks, fi sh nortalities nere I ow unti I about week 10 when they i ncreased consi derably. Fi sh that di ed in the treat nent tanks usual ly shoved cl inical si gns of BKD, incl uding suol I en abdomens and exopht hal nos; nortal ities anong control fish did not. In general, fish survi ving throughout the experi nent fed wel I, grew were active, and showed Iittle clinical evi dence of BKD. Treatnent fish grew si gni fi cantl y faster than control fi sh (Fi gure 4), however di fferences in l ength probably had little infl uence on the predati on tri als (see di scussion).

Het erogenei ty anal ysi s showed that the repl i cate predati on tri al s were honogenous ( Table 1), and the pool ed data reveal ed that BKD chal l enged fi sh were eaten in si gni fi cantl y greater 
numbers than control fish. On average, $65 \%$ of the total fi sh consumed were of the treatment group. The BKD profiles of surviving fish were si milar to those observed in the general popul at $i$ ons of treat nent and control fish.

DISCUSSION

A though the preval ence of $\underline{R}$. sal moni narum anong outmigrating sal noni ds in the Col unbi a Ri ver is hi gh (El I ott and Pascho 1992; Sanders et al. 1992), the i mpact of BKD on the survi val of these fish is poorly understood. My results indicate that fi sh i nf ected wi th onl y l ow to moderate, sub-clini cal l evel s of $\underline{R}$. sal moni narum ma be si gni fi cantl y nore vul nerabl e to predati on, thus providing some evi dence of the functi onal, aut ecol ogi cal si gnifi cance of BKD and the rol e it pl ays in affecting the survival of fish in the wid.

Asi de from nortal ity, the effects of BKD on sal moni ds i ncl ude a vari ety of subl ethal physi ol ogi cal and hemat ol ogi cal changes ( Wedeneyer and Ross 1973; Bruno 1986; Bruno and Munro 1986; Iwama et al . 1986). Si milar changes have been reported in fi sh with vi ral (MacMIIan et al. 1980; Haney et al . 1992) or parasi ti c i nf ecti ons (Lai dl ey et al . 1988; Rand and Cone 1990). It appears, however, that effects of sub- opt $i$ mal $f i$ sh heal th on performance characteristics have been I i mited to st udi es of fish wi th parasi tic infections. For example, parasi te infections have 
been shown to reduce the maxi mum swi ming speed of European snel $t$ Osnerus eperl anus and eel Anauil I a anauilla (Sprengel and Lucht enberg 1991), reduce the cardi ac output of rai nbow trout 0 . mvki ss (Tort et al. 1987), i ncrease the susceptibility of rai nbow trout to hypoxi a (Ubo and Wehnert 1986), and i ncrease the oxygen consumpti on of Gasterosteus (Lester 1971). Parasi ti c i nf ecti ons may not, however, si gni fi cantly i ncrease the vul nerabi I ity of fi sh to predati on (Vaughn and Coble 1975; M I inksi 1985). Fi sh di seases have I ong been an i mportant force i n structuring fi sh communities in the Pacific Northuest ( $L i$ et al. 1987); it is cl ear fromthe I ack of data on the autecol ogi cal i mpacts of di sease that possi bl e mechani sns behi nd this structuring force wi I remai $n$ el usi ve.

Because fi sh i $n$ my st udy were subjected to bri ef handl ing and a mild temperat ure i ncrease when they were transferred to the racenay, my resul ts may actual ly be due to the conbi ned effects of di sease and physi ol ogi cal stress. However, because al I fish uere treated in a si mi ar manner, the effects of the exogenous stresses were probabl y mitigated. In the Col unbi a Ri ver, the conbi ned effects of di sease and exogenous stress are a I i kel y scenario for migrating sal mon, but the potential synergistic effects are poorly understood. A though it has I ong been recogni zed that stress can predi spose fi sh to di sease ( see El I is 
1981 for a revi ew), I ess is known about how di sease per se acts as a stressor or how di sease affects the ability of fish to cope with secondary stresses. Vari ous pathogens are known to el icit characteri sti c stress responses in fi sh (Robertson et al. 1987; Lai dl ey et al 1988; Haney et al 1992) and affect thei $r$ abi I ity to respond to multi ple stresses (Barton et al. 1986). Because physi cal stress can qui ckl y mani fest defi ci ts i n predator avoi dance (011a and Davi s 1989; Mesa 1992; O I a et al. 1992), an underst andi ng of the i nteracti ons bet ween di sease and exogenous stress may provi de i nsi ght into the compl ex behavi ors associ ated wi th predat or avoi dance.

Tho factors that could have inf I uenced the out cone of the predation trials--severity of infection and si ze differences bet ween treat ment and cont rol fi sh-- vere probabl y i nconsequential. The maj ority of fish eaten in the predation tri al s probabl y had I ow to moderate i nf ecti on I evel s because BKD profiles of surviving fish were si milar to the general population of test $\mathrm{fi}$ sh and severel $y$ i nf ected fi sh were rel at $i$ vel $y$ inf requent and usual Iy di ed in the hol ding tanks. Because the mai $n$ emphasi s of my study was to use fi sh with sub-cl i ni cal i nf ecti ons, I never knowi ngl y subj ected fi sh with cl i ni cal sïgns of BKD to predation. The distributi on of ELISA val ues for fïish in my study were simlar to those observed for various sal moni ds 
in the Col unbi a Ri ver (El I i ott and Pascho 1992), suggesting, perhaps, that $\mathrm{my}$ resul ts are representati ve of predat or-prey interactions in natural waters. A though the si ze differences of $\mathrm{fi}$ sh in the two groups vere unexpected, northern squauf i sh actual Iy show a preference for snal ler prey and al I prey rel eased nere vul nerable to predators of the size I used (Poe et al. 1991), thus maki ng any si ze sel ecti on unl $i$ kel $y$.

Uni que to my study was the use of an i mersi on chal I enge to i nduce BKD in the treat nent fi sh, which contrasts markedly with the most wi del y adopted nethod of i nj ecti on (Murray et al . 1992). The advantages of i mersi on chal I enges have been di scussed by Murray et al . (1992) and i ncl ude a reduced I i kel i hood to over whel $m$ the i nnate BKD resi stance of fi sh, a cl oser si mul ation of the natural routes of i nf ection, and no addi ti onal stress due to handl ing. The di sadvantages of the i mersi on chal l enge i ncl ude the requi renent of a I arge anount of i nocul um and a I ong ti me peri od for progressi on of the di sease. Because most studi es of the ef fects of BKD have used i njecti on to i nduce i nf ection, the i mersi on chal I enge provi des an opport uni ty for st udy under nore nat ural condi ti ons.

Despi te uncertai nty i n nortal ity esti nates, predati on is now consi dered to be a si gni fi cant contri but or to the previ ously unexpl ai ned nortal ity of out-migrati ng $\mathrm{j}$ uveni I e sal noni ds i $n$ the 
Col unbi a Ri ver ( $R i$ enan et al . 1991). My resul ts i ndi cate the rol e BKD may pl ay in predator-prey interactions, thus ascribing sone ecol ogi cal si gni fi cance to this di sease. This is a study in progress; fut ure nork wil conti nue to address the effects of BKD on predat or avoi dance ability, netabol i c scope, snol ti fi cati on, and the i nteracti ons of BKD and secondary stresses.

\section{REFERENCES}

Austi n, B. , T. $M$ Enbl y, and M Goodf el I ow 1983. Sel ecti ve i sol ati on of Reni bacteri um sal noni narum FEMS ( Federati on of European M crobi ol ogi cal Soci eti es) Mcrobi ol ogy Letters 17:111-114.

Banner, CR. , J.S. Rohovec, and J . L. Fryer. 1983. Reni bact eri um sal moni narum as a cause of nortal i ty anong chi nook sal non i n sal t water. Journal of the Wbrld Mari cul ture Soci ety 14:236-239.

Barton, B. A, C. B. Schreck, and L. A Si gi snondi . 1986. Mul ti ple acute di st urbances evoke cumul ati ve physi ol ogi cal stress responses in j uveni l e chi nook sal mon. Transacti ons of the Aneri can Fi sheri es Soci ety 115: 245- 251.

Bruno, D. W 1986. Changes in serum paraneters of rai nbow trout, Sal no aai rdneri Ri chardson, and AtI anti c sal mon, Sal no sal ar L. , i nf ect ed wi th Reni bacteri um sal noni narum J ournal of Fi sh Di seases 9:205-211. 
Bruno, D. W, and A. L. S. Munro. 1986. Hemat ol ogi cal assessment of rai nbow trout, Sal no qai rdneri Ri chardson, and AtI anti c sal non, Sal no sal ar L. , i nf ect ed wi th Reni bacteri um sal moni nar um J ournal of Fi sh Di seases 9:195-204.

El I i ott, D. G , R. J. Pascho, and G. L. Bul I ock. 1989.

Devel opnents in the control of bacteri al ki dney di sease of sal noni d fi shes. Di seases of Aquati c Organi sns 6: 201- 215.

El I i ott, D. G , and R.J. Pascho. 1991. J uveni I e fi sh

transportati on: I mpact of bacteri al ki dney di sease on survi val of spri ng/ summer chi nook sal non stocks. , Annual Report, 1989, prepared by the U. S. Fi sh and V'I dl i fe Servi ce, Seattle, Whshi ngt on, for the U.S. Army Corps of Engi neers, Wal I a Wil Ia, MA

El I i ott, D. G , and R. J. Pascho. 1992. J uveni I e fi sh

transportati on: I mpact of bacteri al ki dney di sease on survi val of spring/ summer chi nook sal mon stocks. Annual Report, 1990, prepared by the U. S. Fi sh and Vill dl i fe Servi ce, Seattle, Wishi ngt on, for the U.S. Army Corps of Engi neers, Whl I a Wil Ia, WA

El I s, R. W, A.J. Novot ny, and L. W Harrel I. 1978. Case report of ki dney di sease i n a wi I d chi nook sal non, Oncorhvnchus tshawut scha, in the sea. J ournal of $V^{*} / \mathrm{dl}$ ife Di seases 14:120-123. 
El I i s, A E. 1981. Stress and the modul ati on of def ence mechani sns in fi sh. Pages 147-169 i n A D. Pi ckeri ng, edi tor. Stress and fi sh. Academic Press, New York, NY. Fryer, J. L. , and J.E. Sanders. 1981. Bacteri al ki dney di sease of sal noni d fi sh. Annual Revi ews i n M crobi ol ogy 35: 273298.

Haney, D. C. D. A Hursh, M C. M x, and J.R. W'inton. 1992. Physi ol ogi cal and henat ol ogi cal changes i n chum sal non artificial ly infected with erythrocytic necrosis vi rus. Journal of Aquati c Ani mal Heal th 4: 48-57.

Iwama, G.K., G.L. Greer, and D. J . Randal I . 1986. Changes i n sel ected haenat ol ogi cal paraneters in j uveni l e chi nook sal non subj ected to a bacteri al chal lenge and a toxi cant. J ournal of Fi sh Bi ol ogy 28: 563-572.

Lai dl ey, C. W, P. T. K. Wbo, and J . F. Leat her I and. 1988. The stress-response of rai nbow trout to experi mental i nf ecti on with the bl ood parasi te Crvptobi a sal mositi ca Katz, 1951. J ournal of Fi sh Bi ol ogy 32: 253-261.

Lester, R.J.G 1971. The i nf I uence of Schi stocephal us pl erocercoi ds on the respi raton of Gasterosteus and a possible resulting effect on the behavi or of the fish. Canadi an J ournal of Zool ogy 49:361-366.

Li , H W, C. B. Schreck, C. E. Bond, and E. Rextad. 1987. Fact ors 
i nf I uenci ng changes i n fi sh assenbl ages of Paci fi c Northwest streans. Pages 193-202 in Mattheus, WJ., and DC. Hei ns, edi tors. Communi ty and Evol uti onary Ecol ogy of North Aneri can Stream Fi shes. Uni versi ty of Okl ahom Press, Norman, Okl ahoma.

MecM I I an, J.R., D. Mul cahy, and M Landol t. 1980. Vi ral erythrocytic necrosi s: sone physi ol ogi cal consequenses of i nf ecti on i n chum sal mon (Oncorhvnchus keta). Canadi an J ournal of Fi sheri es and Aquati c Sci ences 37: 799-804.

Mesa, MG 1992. Effects of mul ti pl e acute di sturbances on the predat or avoi dance, physi ol ogy, and behavi or of $\mathrm{j}$ uveni I e chi nook sal non. p. 50-62. In T. P. Poe [ ed. ] Si gni fi cance of sel ecti ve predatīion and devel opment of prey protection measures for j uveni lle sal noni ds i n Col unbi a and Snake Ri ver reservoi rs. Annual Progress Report to the Bonnevi I le Power Adminstrati on, U. S. Fi sh and Vill dl ife Servi ce, Cook, WA Sokal and Rohl f. 1981. Bi onetry. WH Freeman and Co., New York.

M li nski, M 1985. Ri sk of predati on of parasitized sti ckl ebacks (Gaster ost eus acul eat us L.) under compet i ti on for food. Behavi our 93: 203- 216.

M tchum D. L. , L. E. Sherman, and G T. Baxter. 1979. Bacteri al ki dney di sease in feral popul ations of brook trout 
(Sal vel i nus fonti nal is), brown trout (Sal mo trutta), and rai nbow trout (Sal no aai rdneri). J ournal of the Fi sheri es Research Board of Canada 36: 1370- 1376.

Murray, C. B. , T. P. T. Evel yn, T. D. Beacham L. W Barner, J. E. Ket cheson, and L. Prosperi-Porta. 1992. Experi nental i nducti on of bacteri al ki dney di sease i $n$ chi nook sal non by i mersi on and cohabi tati on chal l enges. Di seases of Aquat i c Organi sns 12:91-96.

Q I a, B. L. , and MW Davis. 1989. The role of I earni ng and stress in predator avoi dance of hatchery-reared coho sal non (Oncorhvnchus ki sutch) j uveni l es. Aquacul t ure 76:209-214. Q I a, B. L. , M W Davi s, and C. B. Schreck. 1992. Compari son of predat or avoi dance capabi l i ti es wi th corti costeri od l evel s i nduced by stress i $\mathbf{n}$ jueni l e coho sal non. Transacti ons of the Aneri can Fi sheri es Soci ety 121: 544-547.

Pascho, R. J ., and D. Mul cahy. 1987. Enzyne- I i nked i munosor bent assay for a sol ubl e anti gen of Reni bacteri um sal noni narum the causati ve agent of sal noni d bacteri al ki dney di sease. Canadi an J ournal of Fi sheri es and Aquati c Sci ences 44: 183191.

Pascho, R.J., D. G El I ott, R. W Mal lett, and D. Mul cahy. 1987. Comparison of five techni ques for the detection of Reni bacteri um sal noni nar um i n coho sal non. Transacti ons of 
the Aneri can Fi sheri es Soci ety 116:882-890.

Pascho, R. J., D. G El Ii ott, and J.M Streuf ert. 1991. Brood stock segregati on of spring chi nook sal mon Oncorhvnchus t shawut scha by use of the enzyne- I i nked i munosorbent assay (ELISA) and the fI uorescent ant i body techni que (FAT) affects the preval ence and I evel s of Reni bacteri um sal noni narum i nf ecti on i n progeny. Di seases of Aquati c Organi sns 12: 2540.

Paterson, WD. C. Gal I ant, D. Desautel s, and L. Marshal I. 1979. Det ecti on of bacteri al ki dney di sease i $n$ wi I d sal noni ds i $n$ the Margaree Ri ver System and adj acent waters usi ng an i ndi rect fl uorescent anti body techni que. J ournal of the Fi sheri es Research Board of Canada 36: 1464- 1468.

Pet ersen, J.H., M G. Mesa, J. Hal I-Gri suol d, WC. Schrader, G W Short, and T. P. Poe. 1990. Magni tude and dynami cs of predati on on $\mathbf{j}$ uveni I e sal noni ds i $\mathrm{n}$ Col unbi a and Snake Ri ver reservoi rs. Annual Report of Research, 1989-1990. Bonnevi I l e Power Admi ni strati on, Portl and, Oregon.

Poe, T. P. , H. C. Fansel, S. Vi gg, D. E. Pal ner, and L. A Prendergast. 1991. Feedi ng of predaceous $\mathrm{f} i$ shes on outmi grati ng j uveni I e sal noni ds i n J ohn Day Reservoi r, Col unbi a Ri ver. Transacti ons of the Aneri can Fi sheri es Soci ety 120:405-420. 
Rand, T. G , and D. K Cone. 1990. Effects of I chthvophonus hof eri on condi ti on i ndi ces and bl ood chemi stry of experi mental ly infected rai nbow trout (Oncorhvnchus mkiss). J ournal of Vill dl i fe Di seases 26: 323-328.

Rei nan, B. E. , R. C. Beanesderfer, S. Vi gg, and T. P. Poe. 1991. Esti nated l oss of $\mathrm{j}$ uveni l e sal noni ds to predati on by northern squauf i sh, wal l eyes, and smal I nouth bass in J ohn Day Reservoi $r$, Col unbi a Ri ver. Transacti ons of the Aneri can Fi sheri es Soci ety 120: 448- 458 .

Robertson, L., P. Thonas, C. R. Arnol d, and J.M. Trant. 1987. PI asm corti sol and secondary stress responses of red drum to handl ing, transport, rearing density, and a di sease out break. The Progressi ve Fi sh-Cul turi st 49:1-12.

Sanders, J. E., J.J. Long, C. K. Arakawa, J. L. Barthol onew and J.S. Rohovec. 1992. Preval ence of Reni bacteri um sal moni nar um anong downst ream mi grati ng sal noni ds in the Col unbi a Ri ver. J ournal of Aquatic Ani mal Heal th 4: 72-75. Schreck, C. B. 1981. Stress and compensati on in tel eostean fi shes: response to social and physical factors. Pages 295321 in A D. Pi ckering, edi tor. Stress and fi sh. Acadenic Press, New York, New York.

Sprengel, G, and H Lüchtenberg. 1991. I nf ecti on by endoparasi tes reduces maxi mum swi ming speed of European 
smel t Osmerus eperl anus and European eel Angui II a anqui I I a. Di seases of Aquati c Organi sns 11: 31- 35.

Tort, L. , J.J. Whtson, and I . G Pri ede. 1987. Changes i n in vi tro heart performance in rai nbow trout, Sal no qai rdneri Ri chardson, i nf ected wi th Apatenon araci I is ( Di genea). J ournal of Fi sh Bi ol ogy 30: 341-347.

Turaga, P. S. D. , G D. Wéi ns, and S. L. Kaatt ari . 1987. Anal ysi s of Reni bacteri um sal moni narum anti gen producti on in si tu. Fi sh Pathol ogy 22:209-214.

Vaughan, GE. , and D. W Cobl e. 1975. Subl ethal effects of three ectoparasites on fi sh. J ournal of Fi sh Bi ol ogy 7: 283-294. Wedeneyer, G A, and AJ. Ross. 1973. Nutriti onal factors in the bi ochemi cal pathol ogy of corynebacteri al ki dney di sease in the coho sal mon (Oncorhvnchus ki sutch). J ournal of the Fi sheri es Research Board of Canada 30: 296- 298.

Wbo, P. T. K, and S. D. Wéhnert. 1986. Crvpt obi a sal mosi ti ca: suscepti bi l i ty of i nf ected rai nbow trout, Sal mo qairdneri, to envi ronmental hypoxi a. J ournal of Parasi tol ogy 72: 392396. 
Tabl e I . - Resul ts of di fferent $\mathrm{i}$ al predati on experi ments for $\mathrm{j}$ uveni I e chi nook sal non

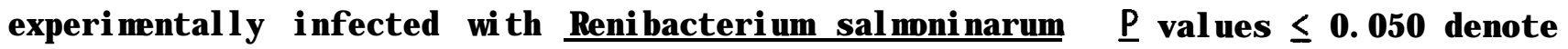
predati on rates that di ffer si gni fi cantl y from random $(50: 50)$.

\begin{tabular}{|c|c|c|c|c|c|c|}
\hline \multicolumn{2}{|c|}{ Nunber Eaten } & \multirow[b]{2}{*}{ Control } & \multirow[b]{2}{*}{ Test } & \multirow[b]{2}{*}{ df } & \multirow[b]{2}{*}{$x^{2}$} & \multirow[b]{2}{*}{$\mathbf{P}$} \\
\hline Replicate & I nf ected & & & & & \\
\hline 1 & 13 & 9 & & 1 & 0.727 & 0.601 \\
\hline 2 & 9 & 7 & & 1 & 0.250 & 0.623 \\
\hline 3 & 11 & 4 & & 1 & 3.267 & 0.067 \\
\hline 4 & 10 & 5 & & 1 & 1.667 & 0.193 \\
\hline 5 & 9 & 3 & & 1 & 3.000 & 0.079 \\
\hline 6 & 10 & 11 & & 1 & 0.048 & 0.822 \\
\hline 7 & 15 & 5 & & 1 & 5.000 & 0.024 \\
\hline 8 & 15 & 8 & & 1 & 2.130 & 0.140 \\
\hline 9 & 9 & 7 & & 1 & 0.250 & 0.623 \\
\hline 10 & 11 & 0 & & 1 & 11.000 & 0.001 \\
\hline 11 & 11 & 6 & & 1 & 1.471 & 0.223 \\
\hline 12 & 8 & 5 & & 1 & 0.692 & 0.589 \\
\hline 13 & 6 & 5 & & 1 & 0.091 & 0.761 \\
\hline 14 & 8 & 5 & & 1 & 0.692 & 0.589 \\
\hline 15 & 11 & 9 & & 1 & 0.200 & 0.659 \\
\hline 16 & 13 & 3 & & 1 & 6.250 & 0.012 \\
\hline 17 & 6 & 5 & & 1 & 0.091 & 0.761 \\
\hline \multirow[t]{2}{*}{18} & 6 & 2 & & 1 & 2.000 & 0.153 \\
\hline & & & Total & 18 & 38.826 & 0.002 \\
\hline \multirow[t]{2}{*}{$\Sigma$} & 181 & 99 & Pool ed & 1 & 24.014 & 0.000 \\
\hline & & & Het erogenei ty & 17 & 14.812 & $>0.500$ \\
\hline
\end{tabular}




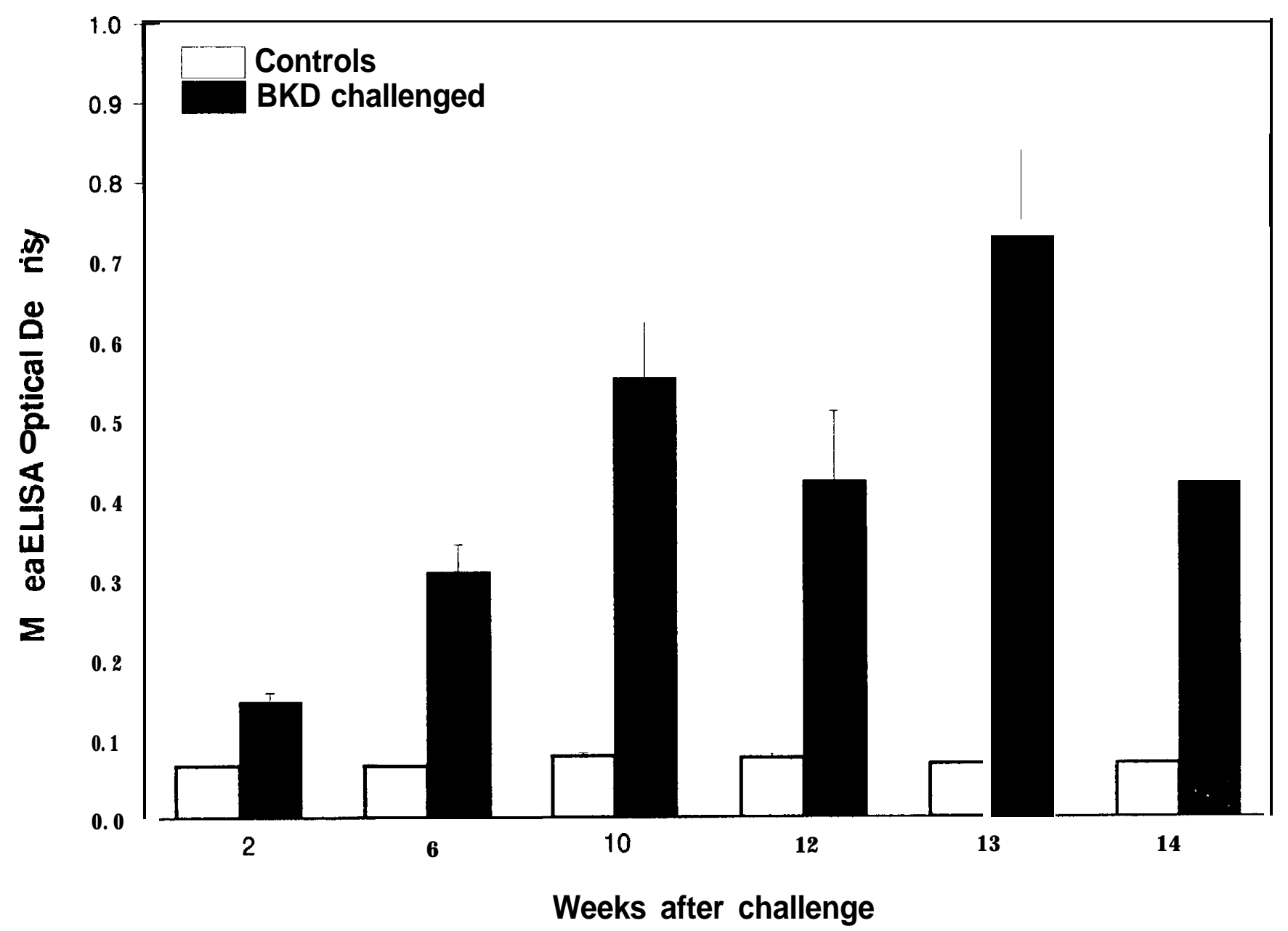



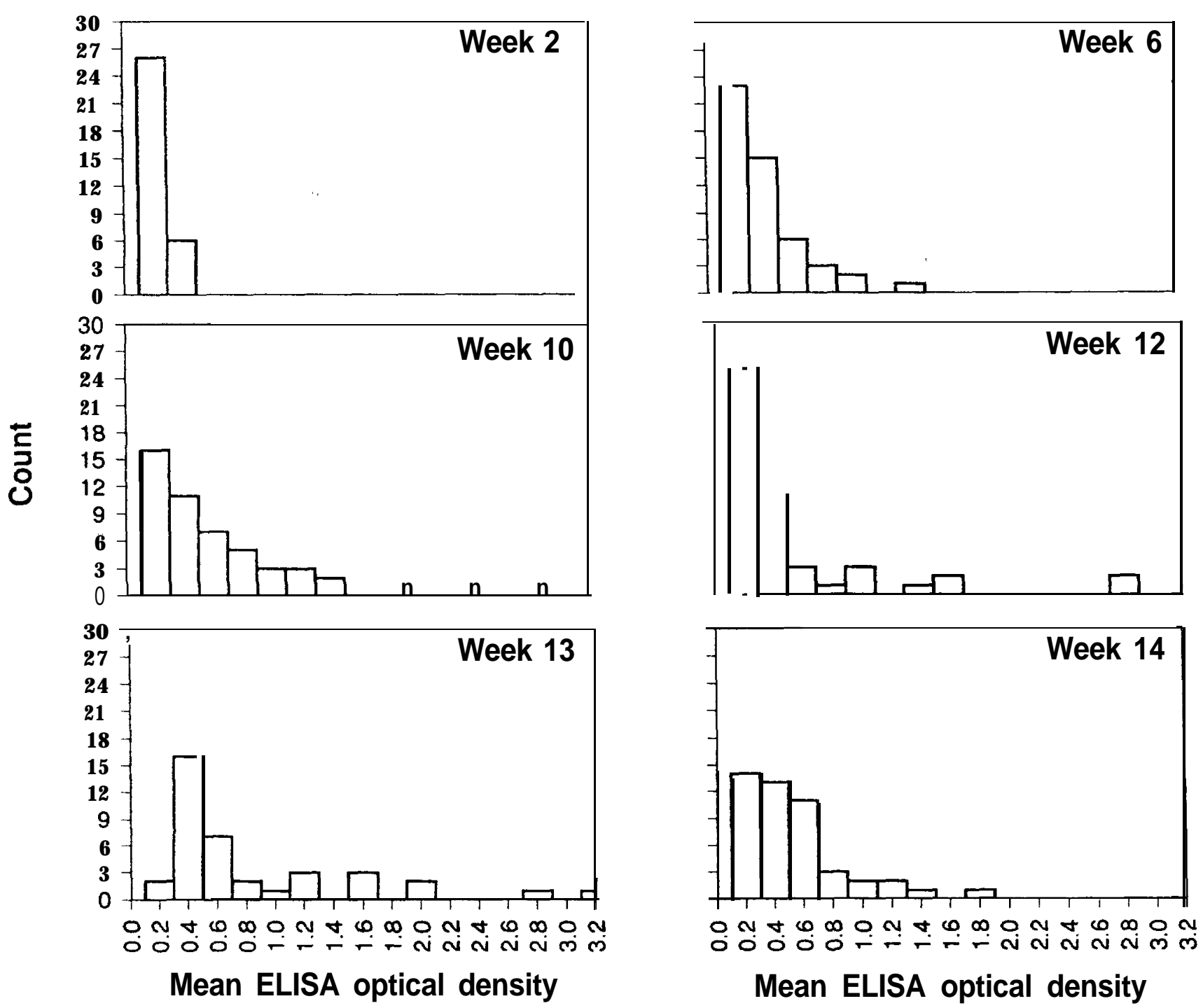


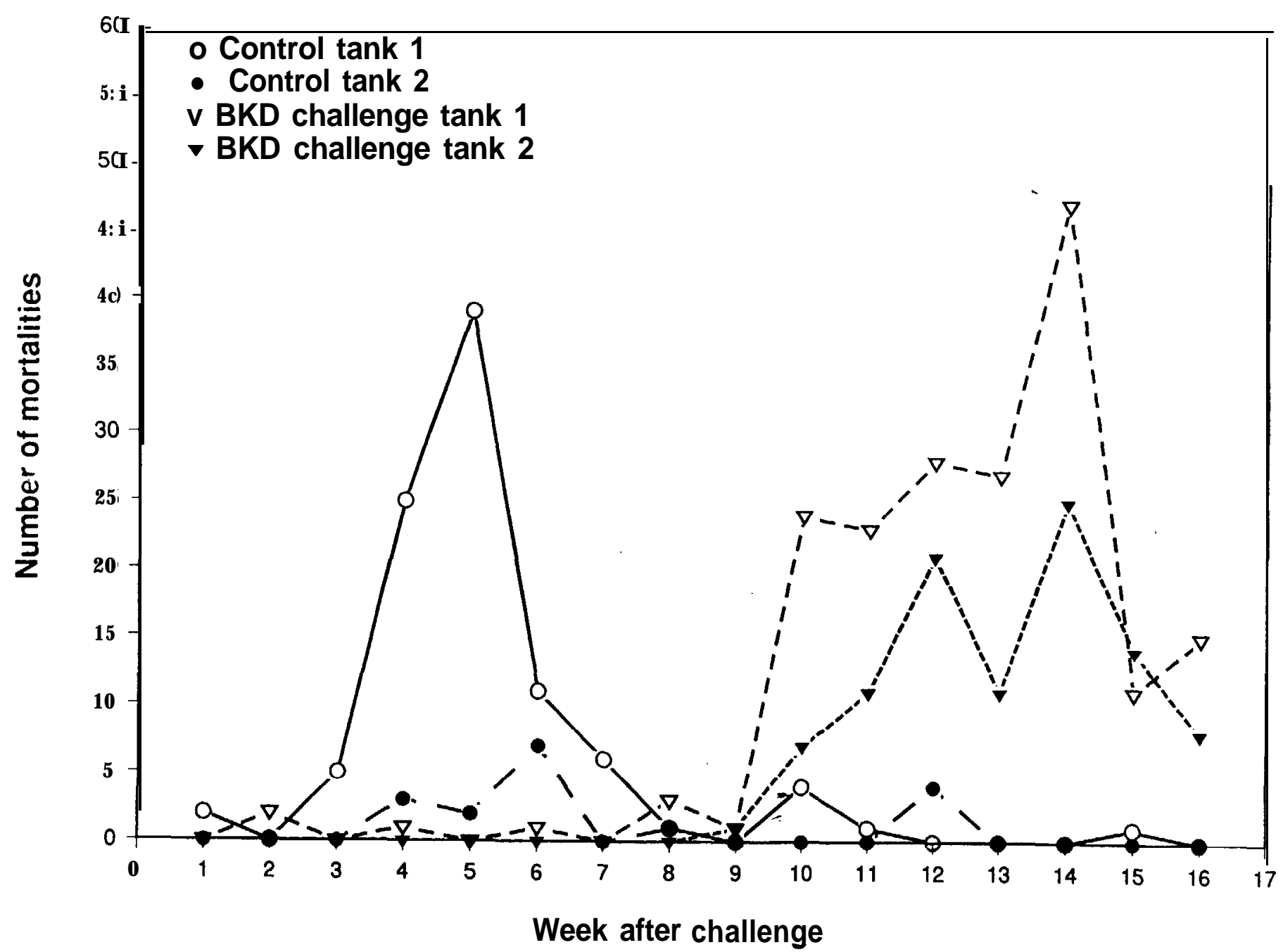




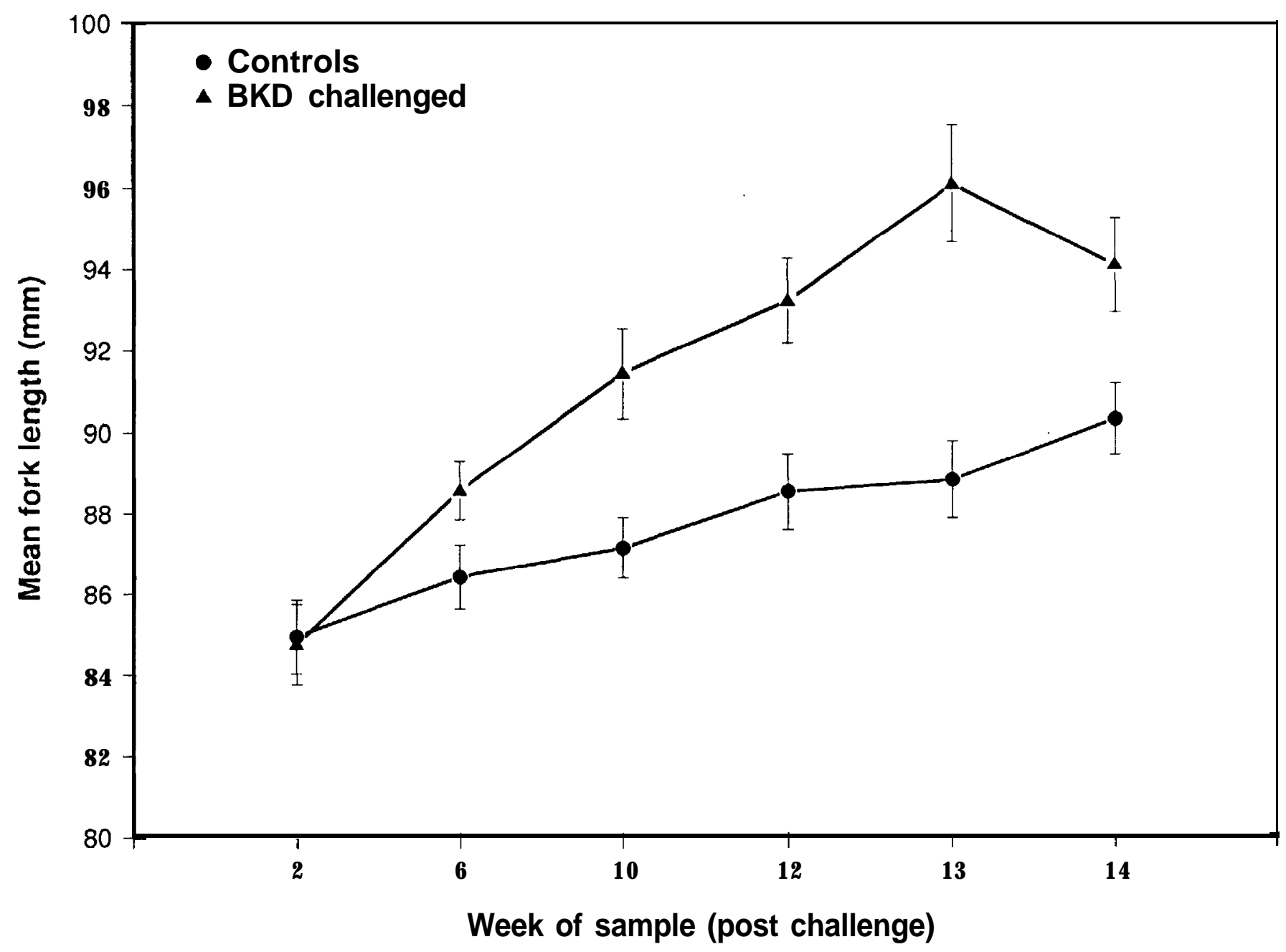


Report 4

\title{
Prolonged Swimming Performance of Northern Squawfish: Can Water Velocity be used to Reduce Predation on Juvenile Salmonids at Columbia River Dams?
}

\author{
Matthew G. Mesa and Todd M. Olson' \\ U.S. Fish and Wildlife Service, National Fisheries Research \\ Center-Seattle, Columbia River Field Station
}

\begin{abstract}
We determined the prolonged swimming performance for two size classes of northern sguawfish Ptvchocheilus oreaonensis at 12 and $18^{\circ} \mathrm{C}$. The percent of fish fatigued was positively related to water velocity and best described by an exponential model. At $12^{\circ} \mathrm{C}$, the estimate of the velocinty at whic $50 \%$ of the fish fatigued (FV50) was 2.91 fork lengths per second (FL/s; $100 \mathrm{~cm} / \mathrm{s}$ ) for medium-sized fish $(30-39 \mathrm{~cm})$ and $2.45 \mathrm{FL} / \mathrm{s}(104 \mathrm{~cm} / \mathrm{s})$ for large fish $(40-49 \mathrm{~cm})$. At $18^{\circ} \mathrm{C}$, estimated FV50 was $3.12 \mathrm{FL} / \mathrm{s}$ (107 cm/s) for medium fish and $2.65 \mathrm{FL} / \mathrm{s}(112 \mathrm{~cm} / \mathrm{s})$ for large fish. Rate of change in percent fatigue was significantly affected by fish size and water temperature. Large fish fatigued at a higher rate than medium-sized fish and all fish fatigued fastre at 12 than at $18^{\circ} \mathrm{C}$. The mean times to fatigue at velocities of $102-115 \mathrm{~cm} / \mathrm{s}$ ranged from 14 to $28 \mathrm{~min}$ and were not significantly affected by fish size or water temperature. Our
\end{abstract}

\footnotetext{
'Present Address: Pacific Power, 9210 S.W. sixt Avenue, 1000 PSB, Portland, Oregon 97204
} 
results indicate that water velocities from 100 to $130 \mathrm{~cm} / \mathrm{s}$ may exclude or reduce predation by norther sguawfish around juvenile salmonid bypass outfalls at Columbia River dams, at least during certain times of the year. We recommend that when constructing new or modifying existing juvenil salmonid bypass facilities the outfall be in high water velocity and distant from eddies, submerged cover, and littoral areas. 


\title{
Report 5
}

\section{MOVEMENTS AND DISTRIBUTION OF RADIO-TAGGED NORTHERN SQUAWFISH NEAR THE DALLES DAM}

\author{
R.S. Shively, S.R. Hirtzel, L.L. Mann, T.L McGuire, \\ and G. Holmberg
}

\section{U.S. Fish and Wildlife Service, National Fisheries Research} Center-Seattle, Columbia River Field Station

\begin{abstract}
We monitored the movements and distribution of 93 radio-tagged northern sguawfish (Ptvchocheilus oreqonensis) in The Dalles Dam tailrace to determine how they responded to changes in dam operations. Three fixed site receiver stations with a total of 17 yagi antennas were established at the dam to monitor the general movements and distributions of tagged northern sguawfish. The fixed site receiving stations performed well and provided useful information but a high rate of transmitter failure compromised the results. While there was variation in some movements of individuals, similar patterns of group behavior were observed. Typically, northern sguawfish remained at an antenna location for several hours before moving, allowing us to identify locations where they were likely to occur. Northern squawfish were most often recorded near the ice-trash sluiceway outfall or within the spill basin. Distributions of northern sguawfish were significantly different during various modes of operation of the spillway and ice-trash sluiceway. Northern sguawfish located
\end{abstract}


near the spill basin during times of no spill tended to move downriver when spilling started. When the ice-trash sluiceway was operating, northern squawfish were frequently recorded in the vicinity of the outfall, but when operation ceased, observations in this area declined. 


\section{ACKNOWLEDGEMENTS}

Milton Hunter and Conrad Frost (USFWS) provided valuable assistance with equipment setup. We also thank Bob Dach (USACOE) for coordinating our research activities at The Dalles ,Dam and providing useful information regarding project operations, We are grateful to Cameron Grant (Lotek Eng.) for assisting in the design, configuration, and setup of telemetry equipment as well as answering many questions. We also appreciate the cooperation of Columbia River Intertribal Fish Commission and Washington Department of Wildlife personnel in recovering radio transmitters. Tom Poe, Bill Nelson, and Dena Gadomski provided helpful suggestions to earlier drafts of this report. Lastly, we thank Bill Maslen (BPA) for administering the contract and providing assistance to the study, and Dick Banning Aircraft Services Manager (BPA) and his crew for providing helicopter flight time. 


\section{INTRODUCTION}

Various studies in the lower Columbia and Snake rivers indicate that predators, especially northern squawfish (Ptychocheilus oregonensis), congregate in tailrace areas below dams and consume large numbers of juvenile salmonids (Poe et al. 1991; Rieman et al. 1991; Vigg et al. 1991). Predator distributions and abundances in tailraces vary over short (hours or days) and long (months) time periods in response to seasonal juvenile salmonid passage, river flow, and dam operating conditions. Information regarding the movement patterns of predators and prey, especially overlaps in distribution, and the diet of predators would be useful in locating, modifying, and operating juvenile bypass systems (JBS) at Columbia and Snake river dams. Location of juvenile bypass outfalls is an important consideration in the design of JBS because losses due to predation could negate the survival benefits of these systems. If the factors limiting northern squawfish predation on juvenile salmonids were identified, this information could be used to site JBS outfalls.

In 1984 and 1985, the U.S. Fish and Wildlife Service and the Oregon Department of Fish and Wildlife conducted a radio telemetry study of northern squawfish in the McNary Dam tailrace

to describe their distribution during different flow regimes (Faler et al. 1988). The distribution of northern squawfish was strongly influenced by river discharge and current velocity (i.e. fish were not found in velocities $>70 \mathrm{~cm} / \mathrm{s}$ ) and suggested that predation may be reduced in certain areas if high water velocities $(>100 \mathrm{~cm} / \mathrm{s})$ were maintained near JBS outfall areas. Additionally, Mesa and Olson (In press) conducted swimming stamina experiments with northern squawfish to determine prolonged swimming performance. They found that northern squawfish quickly fatigue at water velocities $>100 \mathrm{~cm} / \mathrm{s}$ and recommended that JBS outfalls be located in high water velocity areas, distant from eddies, submerged cover, and littoral areas.

With the construction of a new JBS at The Dalles Dam and proposed modifications to existing JBSs at other Columbia River Dams, it is important to develop biological criteria for 
locating JBS outfall sites. Therefore, we initiated a study to monitor the movements and distribution of northern squawfish in the tailrace area of The Dalles Dam. Our objectives were to develop and test a radio telemetry system that would monitor northern squawfish activity in The Dalles Dam tailrace. Once operational, we tried to determine movement, distribution patterns, residence times, and behavior of northern squawfish in The Dalles Dam tailrace area with regard to dam operations and environmental conditions. 


\section{METHODS}

The Dalles Dam (TDA) is a hydroelectric facility located at river kilometer 307 (rkm) of the Columbia River and is operated by the U.S. Army Corps of Engineers (USACOE). The dam extends $2.4 \mathrm{~km}$ from the powerhouse on the Oregon shore to the navigation lock on the Washington shore (Figure 1). The spill gates extend $0.4 \mathrm{~km}$ from the north fishway and were operated for juvenile fish passage daily 1 May to 23 August from 2000 to $0400 \mathrm{~h}$. The powerhouse is located by the east fishway and contains 22 turbine units. The ice-trash sluiceway i s I ocated west of the powerhouse and discharged water $24 \mathrm{~h}$ prior to 24 June, thereafter sluiceway discharge was stopped during times of spill.

Operating conditions and several environmental variables at TDA were monitored in conjunction with northern squawfish movements and distributions. We obtained records from the USACOE concerning dam operations (e.g. spill gate and ice-trash sluiceway operation), flow (total, turbine, and spill), and water temperature. We also measured current velocities twice in TDA tailrace boat restricted zone (BRZ) along five to seven transects at 3 and $8 \mathrm{~m}$ depths using a Swoffer ${ }^{1}$ Model 2200 AA current meter suspended from a boat. Measured current velocities were compared to values derived from a USACOE 80:1 scale model of TDA at similar flow regimes. Water turbidity was measured at weekly or biweekly intervals with a Hach model 210 OP turbidimeter. No information concerning juvenile salmonid passage at TDA was collected in 1992.

Northern squawfish that were to be implanted with radio transmitters were collected within $3.5 \mathrm{~km}$ of TDA BRZ by boat electrofishing or removal from a Merwin trap operated by the University of Washington located near the east fish ladder. Transmitters were digitally-encoded and measured $14 \times 43 \mathrm{~mm}$ and weighed $4.4 \mathrm{~g}$ in water. Digitally-encoded transmitters allow as many as 50 transmitters on the same frequency and can be individually identified, reducing the

\footnotetext{
'Use of brand names does not imply endorsement by the U.S.
} Government. 


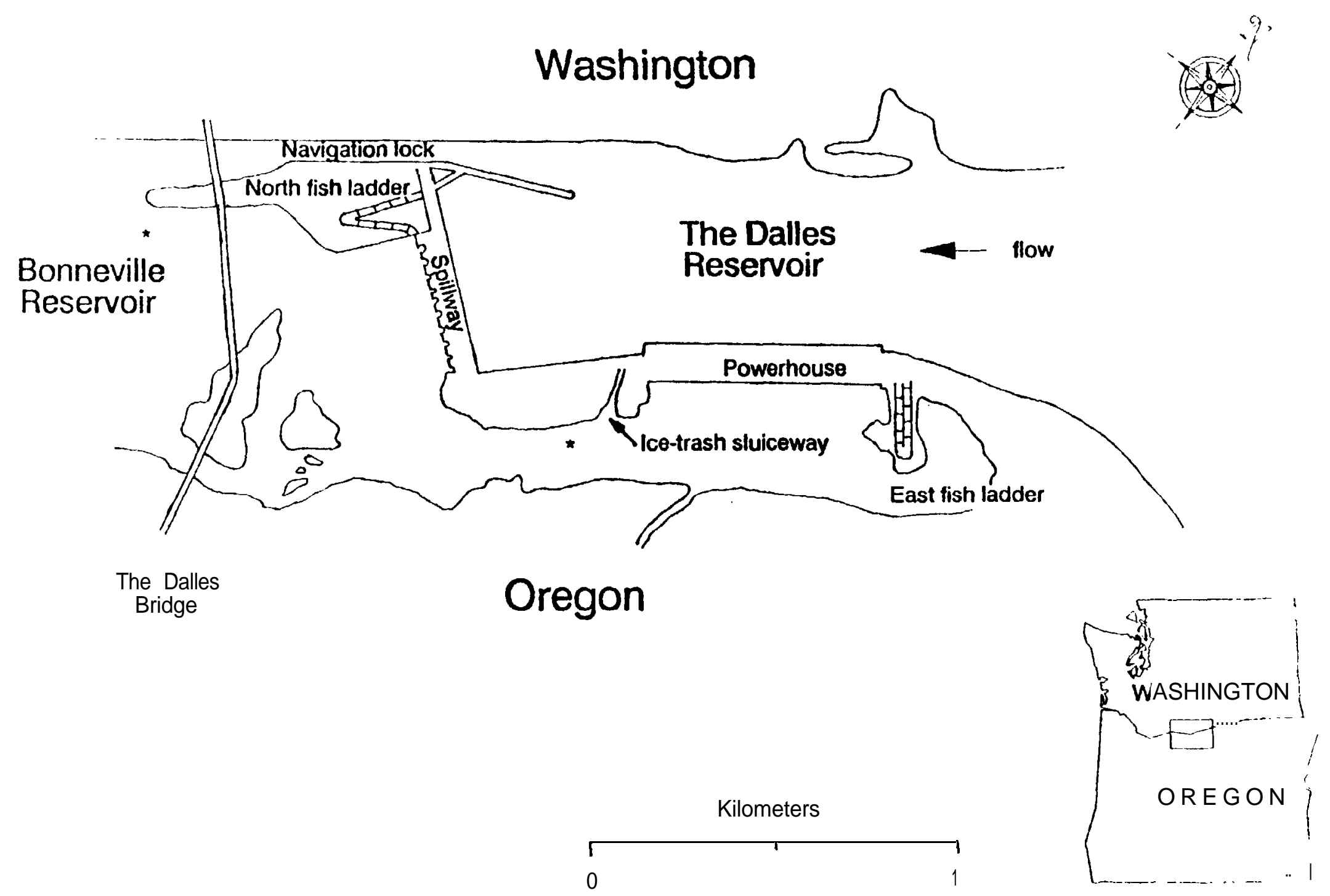

Figure 1. Locations of the ice-trash sluiceway, spillway, powerhouse, fish ladders, and the two proposed juvenile bypass system outfall sites $\left({ }^{*}\right)$ at The Dalles Dam. 
amount of time needed to scan all frequencies. Fish were anesthetized in a $133 \mathrm{mg} / \mathrm{L}$ solution of tricaine methanesulfonate (MS-222). Fish length (fork and total), date, time, capture area, and transmitter frequency and code were recorded. Sex was not determined for radio-tagged fish.

Anesthetized fish were placed ventral side up in a V-shaped trough in the anesthesia tub and the gills were continuously flushed with the anesthetic solution. A $2 \mathrm{~cm}$ incision was made mid-ventrally through the body wall anterior of the pelvic girdle. A specula was inserted into the incision to lift the pelvic girdle away from the internal organs and a $10 \mathrm{~cm}$ hypodermic needle was pushed mid-ventrally through the body wall posterior of the pelvic girdle, passed through the body cavity and the end pushed out through the incision. The transmitter antenna wire was inserted into the needle, passed through the body cavity, and then the needle was removed. The transmitter was inserted into the body cavity and three to five individual sutures were used to close the incision. The gills were flushed with fresh water while the incision was being closed to begin reviving the fish. Two antiseptic solutions, $2 \%$ chlorhexidene and diluted iodine, were applied to the sutured incision and antenna wire exit wound. Fish were placed in a recirculating live-well to recover before being released near the point of capture.

We established three fixed receiver stations at TDA to monitor northern squawfish movements and distribution at the two proposed JBS outfall sites (below the ice-trash sluiceway outfall and the main river channel south of navigational lock peninsula) as well as other areas of interest in the BRZ (Figure 2). A fixed receiver station consisted of a Lotek SRX_400 receiver, an antenna switchbox (that allowed the receiver to monitor up to eight different antennas), 4 and 9-element yagi antennas, and a $12 \mathrm{~V}$ battery. Antenna arrays were configured to monitor areas with some overlap of coverage by individual antennas. Approximate areas of antenna coverage were determined by repeatedly drifting a transmitter through the BRZ and recording the position of the transmitter when it was received by a particular antenna. Antenna gains and receiver noise blank levels were configured to optimize transmitter signal reception without exceeding the signal saturation threshold of receivers. Fixed receivers were in operation during different time 


\section{Washington}

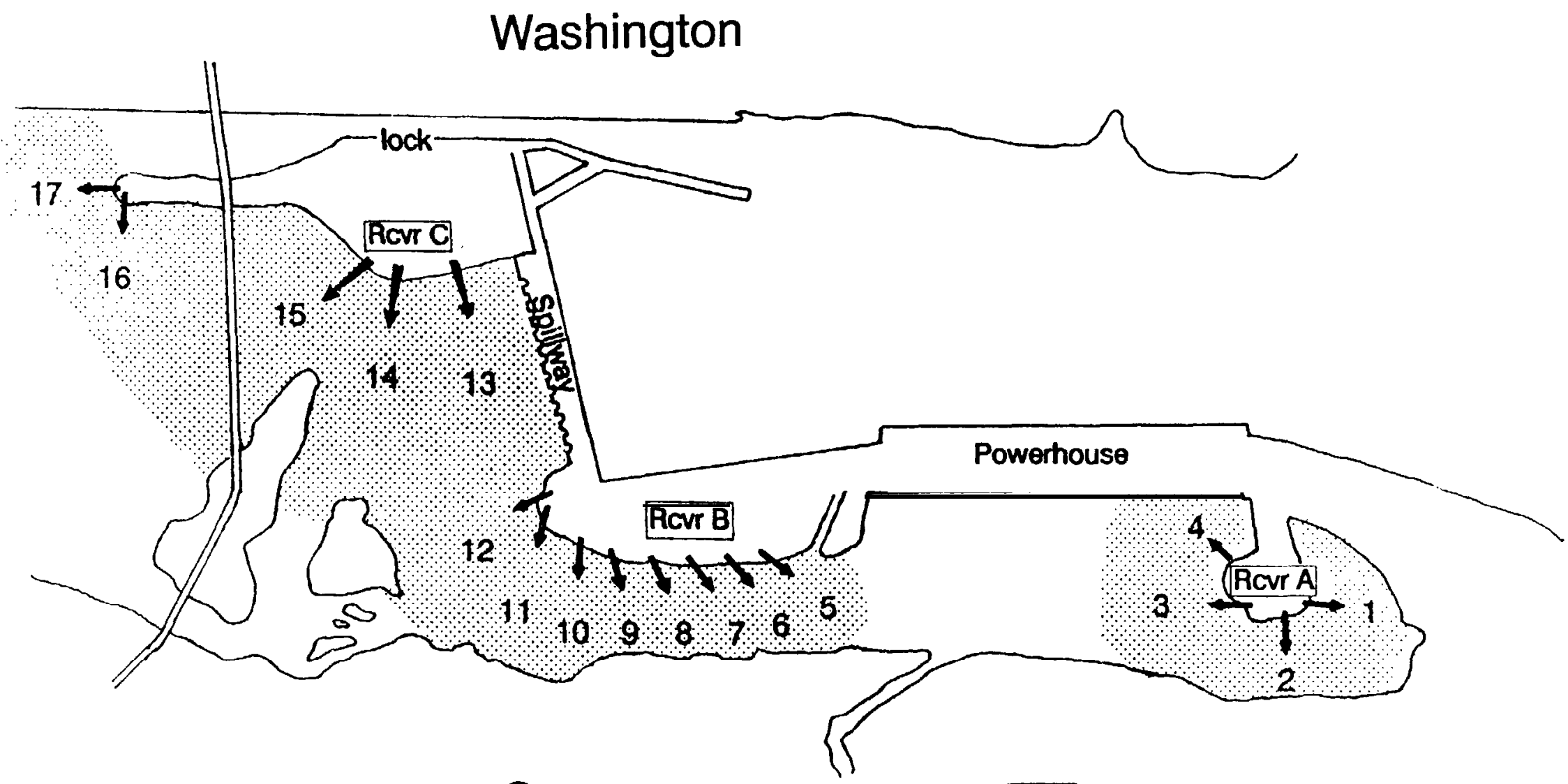

Oregon

Rówe d receiver

$\uparrow$ g-element antenna

1 4-element antenna

area of transmitter reception

Figure 2. Locations of fixed receiver stations, antenna arrays and approximate areas of antenna coverage in The Dalles Dam tailrace. 
periods. Monitoring was initiated on 11 May 1992 for receivers B (area of the ice-trash sluiceway outfall) and $\mathrm{C}$ (area of the spill basin on the north shore). The third fixed receiver, A, began monitoring the area at the east fish ladder on 12 June 1992. Fixed receivers were operated until 4 September, however few valid data were collected after 23 July 1992 due to the low number of transmitters functioning and subsequently not used for analysis. Receivers were routinely removed from fixed antenna arrays for manual tracking. Loss of battery power for the receivers also resulted in gaps in data collection.

In addition to fixed receiver stations, mobile tracking methods (boat, helicopter, and shore tracking) were used to monitor radio-tagged northern squawfish two to four times a week From May through September. For boat tracking, we mounted a 9-element antenna to a $3.7 \mathrm{~m}$ mast capable of rotating $360^{\circ}$. Boat tracking was done in a stop and search manner. Once a signal was received, we followed the direction of strongest signal strength until a reasonable estimate of the location of a radio-tagged fish was made. When tracking from shore, the same antenna/mast system as boat tracking was used to locate fish. Transmitter frequencies were scanned at least twice per stop. If a signal was received, the direction of strongest signal strength was noted and the antenna was moved to other locations to get as many signal bearings as possible to estimate the position of the fish. Aerial surveys were conducted from Bonneville Dam (rkm 232) to the mouth of the John Day River (rkm 350) on 5 June and 10 July to locate radio-tagged fish that had dispersed away from TDA. Before each flight, reference transmitters were placed in the river at known locations to assess our ability to receive transmitters during the aerial survey. A 4-element yagi antenna was mounted to the landing strut of a Bell Jet Ranger helicopter and surveys were flown at air speeds of $60-125 \mathrm{~km}$ per hour at altitudes of 300 to $700 \mathrm{~m}$. Typically, transmitter signals could be received from a distance of at least 3-4 km, depending on the water depth of the radio-tagged fish. Individual fish, however could not be identified due to a combination of low signal strength and engine interference. Following the aerial survey, boat or shore tracking was then conducted to more precisely locate and identify radio-tagged fish. 
Data downloaded from fixed receivers was imported into a relational database to be edited and analyzed. Data were only used when three criteria were met: 1) an exact match of the. transmitter's channel and code was obtained; 2) fish had to be tagged at least seven days, and 3) fish had to display some movement between antennas (i.e. not presumed dead). Radio-tagged fish were assigned a single antenna location per hour based on the antenna the fish was recorded on most often during that hour. If a fish was recorded an equal number of times on two or more antennas within the hour, then antenna location was assigned based on highest average signal strength. This location per hour for an individual fish was considered an observation. These observations were used for further data analysis.

We first compared the frequency distributions of observations at each antenna and fixed receiver locations and also examined the distributions by time of day. We then partitioned the data based on various dam operating conditions to examine how ice-trash sluiceway operation and spill were related to observed movements of northern squawfish. For ice-trash sluiceway operations, we considered three different patterns: $24 \mathrm{~h}$ discharge (open $24 \mathrm{~h}$ ), discharge while on a schedule (open), and no discharge while on a schedule (closed). The amounts of spill discharge, total river flow, and turbine flow were partitioned into three categories based on percentile distributions (O-33rd, 34th-66th, and 67th-100th). Low spill was defined as $85-623 \mathrm{~m}^{\mathbf{3}} / \mathrm{s}$, medium $637-1439 \mathrm{~m}^{3} / \mathrm{s}$, and high $1444-2577 \mathrm{~m}^{3} / \mathrm{s}$. Low total river flow was defined as $1529-4336 \mathrm{~m}^{3} / \mathrm{s}$, medium 4339-5491 $\mathrm{m}^{\mathbf{3}} / \mathrm{s}$, and high $5494-8068 \mathrm{~m}^{\mathbf{3}} / \mathrm{s}$. Low turbine flow was defined as 1340-361 1 $\mathrm{m}^{3} / \mathrm{s}$, medium $3614-4868 \mathrm{~m}^{3} / \mathrm{s}$, and high $4871-7360 \mathrm{~m}^{3} / \mathrm{s}$.

We quantified fish movement at fixed receiving locations by two methods. First, we plotted the frequency distributions of the number of hours northern squawfish were continuously recorded at each antenna. This also allowed us to examine the performance of fixed receiver stations. Second, we calculated the probability of a fish moving from one antenna location to another as a measure of fish movement. Only data where there were two or more continuous observations were considered to compute these probabilities. 
We performed several statistical analyses to determine if observed frequencies and distributions of northern squawfish were significantly different with respect to project operations. Log-likelihood ratio Chi-square tests (Zar 1984) were used to determine if observed northern squawfish distribution patterns were significantly different with project operations. The distribution of observations at all possible combinations of ice-trash sluiceway operation, volume of spill, volume of total flow and volume of turbine flow were compared. We performed a test of proportions (Walpole and Myers 1985) to compare differences in observations at an individual antennas with respect to ice-trash sluiceway operation and amount of spill. We also compared median time northern squawfish were recorded at individual antennas with a median test for multisample considerations (Zar 1984) to determine if northern squawfish were recorded for longer periods of time at certain antennas. 


\section{RESULTS}

Discharge (i.e. total, turbine, and spill) was highest in May and decreased with time and water temperature ranged between $13-22^{\circ} \mathrm{C}$ (Figure 3). Measured current velocities $<\mathrm{IOOcm} / \mathrm{s}$ were similar to values derived from the USACOE scale model. Measured velocities $>100 \mathrm{~cm} / \mathrm{s}$ were higher than the model values, which may have been the result of boat movement during measurements in higher current velocities. Water turbidity values downriver of TDA tailrace ranged from 4.7 NTU's on 11 June to 2.1 NTU's on 27 August (X=2.8 NTU's).

We surgically implanted a total of 93 transmitters in northern squawfish from 30 April to 27 May 1932. The majority of northern squawfish $(81 \%)$ radio-tagged were collected in the BRZ (Figure 4). Radio-tagged northern squawfish ranged in size from $332 \mathrm{~mm}$ to $540 \mathrm{~mm}$ fork length $(\bar{x}=439 \mathrm{~mm})$. Ten radio-tagged northern squawfish were caught by Columbia River Inter-tribal Fish Commission personnel at TDA ice-trash sluiceway outfall (two transmitters were recovered 5 d following implantation and were re-implanted in northern squawfish) and four study fish were returned through the Washington Department of Wildlife sport-reward fishery. Sport-reward

angled fish were caught near Bingen, WA (rkm 280), below TDA BRZ (Rkm 306, 2 fish), and the John Day Dam tailrace (rkm 344). All returned fish were females.

The frequent occurrence of non-working transmitters ( 8 of 12 recovered by anglers after 15 May) and the decreasing number of observations at the fixed receiver stations (Figure 5) suggested transmitters were failing or that radio-tagged fish had moved away from TDA. Therefore, mobile tracking efforts were intensified and two aerial surveys were conducted to locate radio-tagged northern squawfish.

Downriver of the BRZ most radio-tagged fish were located within $5 \mathrm{~km}$ of the dam. Areas where fish were often located included in the vicinity of The Dalles Bridge Island, along the Washington shore in areas of rock rip-rap, and in shallow areas around the islands located about $1.5 \mathrm{~km}$ downriver of The Dalles Bridge. 


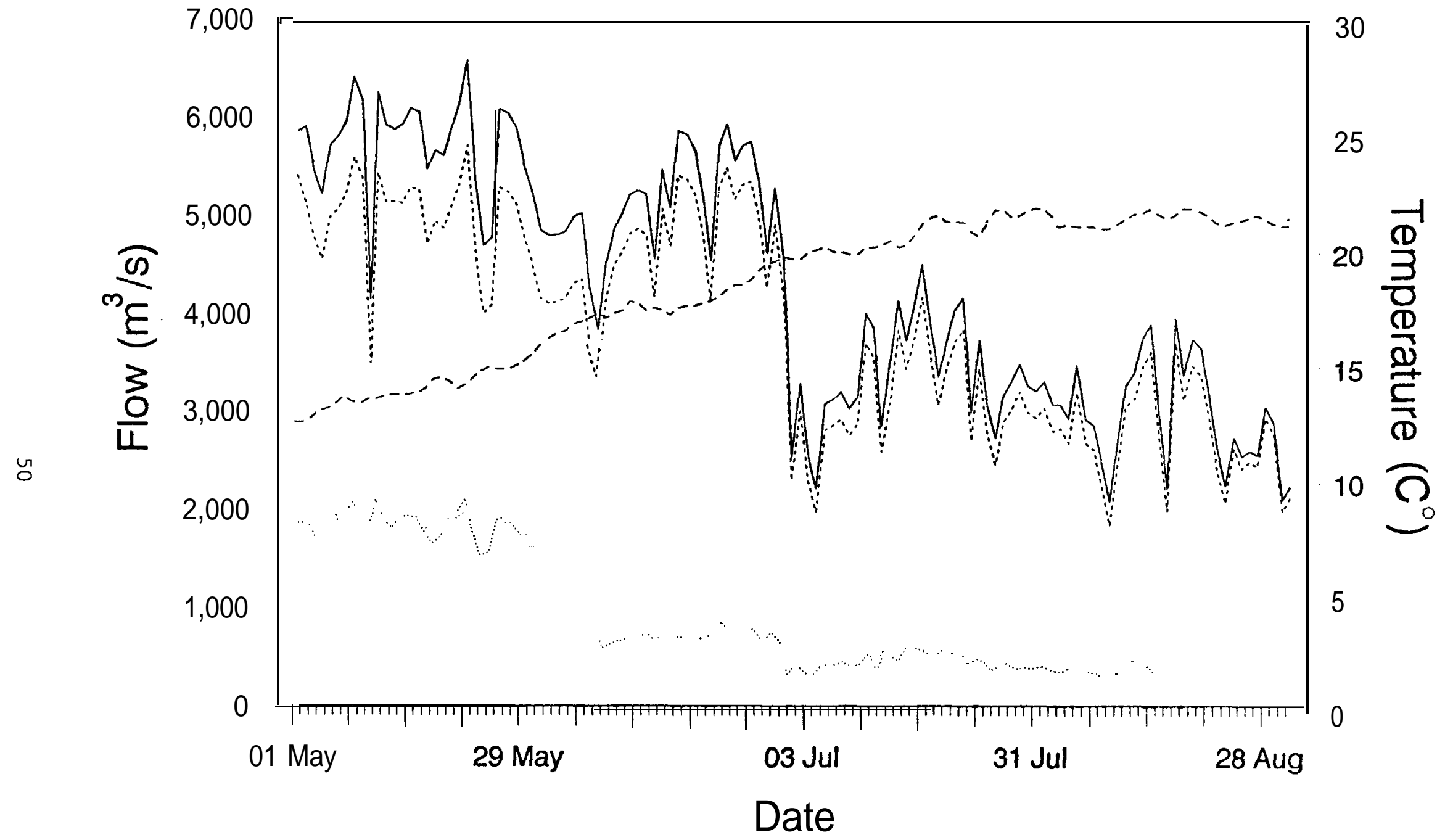

Total Discharge Turbine Discharge Spill Discharge- Mean Daily Temp.

Figure 3. Summary of daily total discharge, turbine discharge, spill discharge and daily water temperature at The Dalles Dam, 1992. 


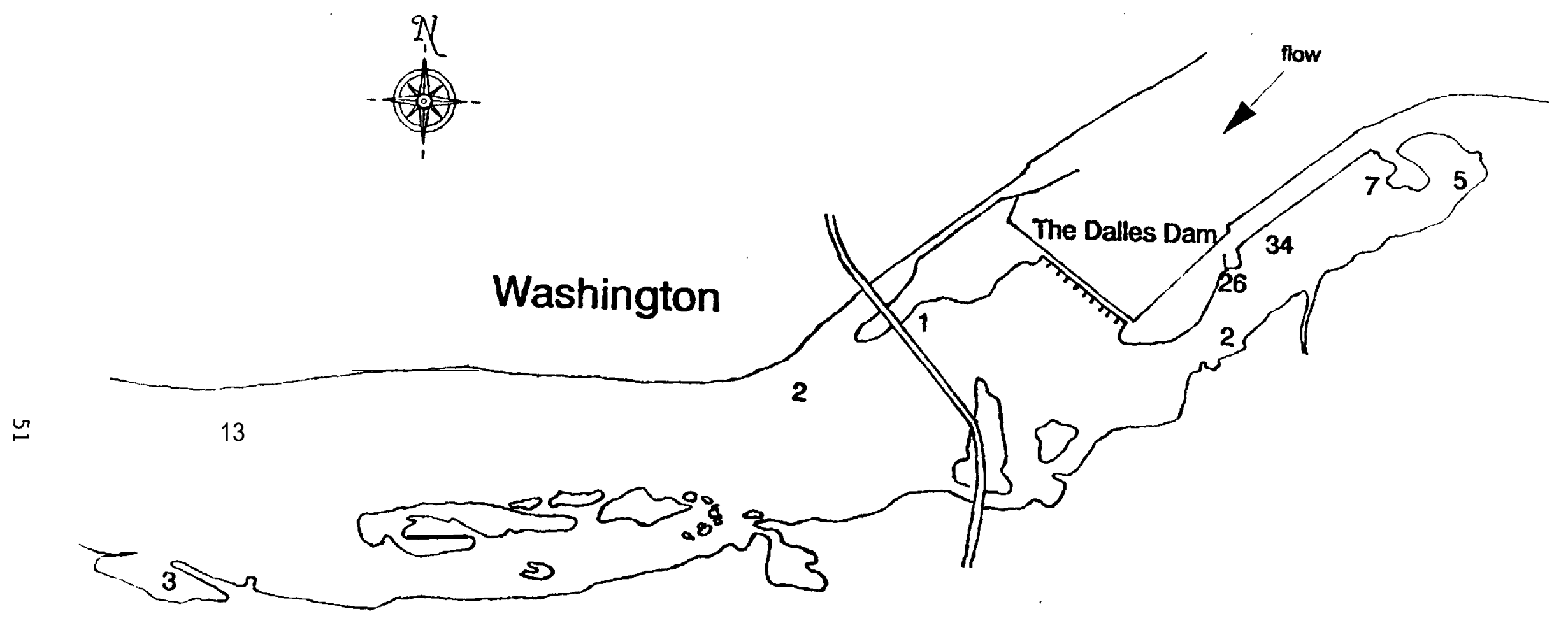

\section{Oregon}

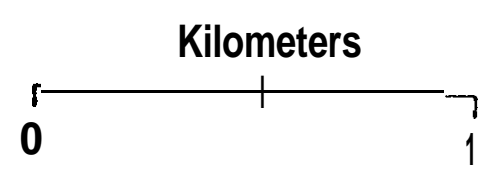

Fi gure 4. Locations and numbers of northern squwafish collected for radio transmitter implantation. 


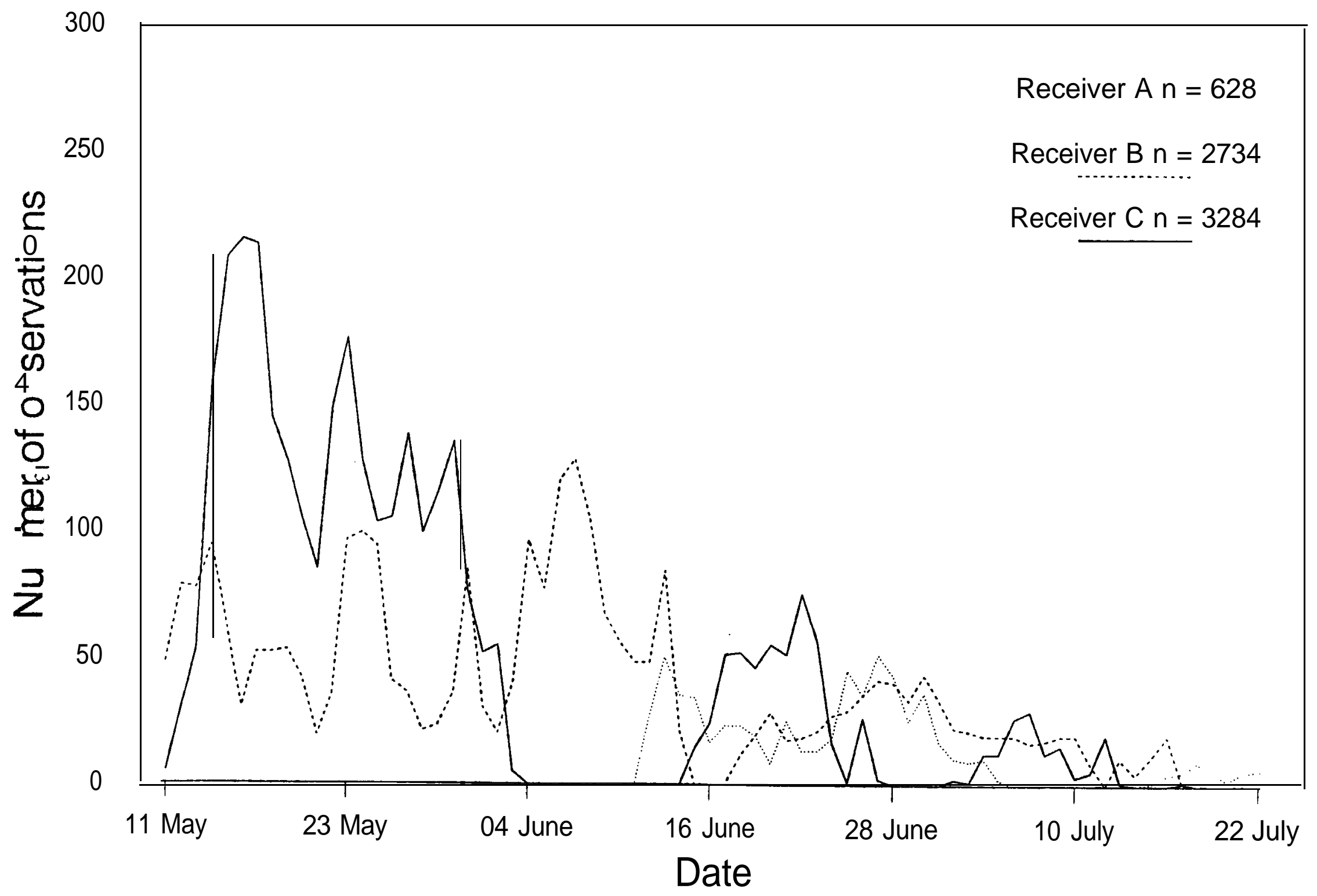

Figure 5. Number of observations of radio-tagged northern squawfish by day from fixed receivers located at The Dalles Dam tailrace, Columbia River. 
During the first aerial survey (5 June) the majority of transmitter signals were received in the vicinity of TDA; however due to electromagnetic interference and safety constraints it was impossible to identify individual transmitters. We did confirm that at least 8 radio-tagged fish had moved upriver of TDA. Two of these fish were located $9.6 \mathrm{~km}$ upriver of TDA near Brown's Island, one fish was located near the east end of Miller Island (rkm 331), and another fish was 1.6 $\mathrm{km}$ above the Highway 97 bridge (rkm 336) near the Oregon shore. The remaining four tagged fish were located in the John Day Dam tailrace. The second aerial survey flown on 10 July detected about 10-15 fish. Two radio-tagged fish had moved 36 and $61 \mathrm{~km}$, respectively, downriver of TDA. Three tagged fish were detected upriver of TDA; one fish near Brown's Island and two fish in the JDA tailrace. The remaining fish were located in the vicinity of TDA.

Fixed receivers recorded 50 of the 93 radio-tagged northern squawfish and a total of 6,646 observations (Table 1). Observations on receiver A were concentrated on antennas 3 and 4 that monitor the area close to the powerhouse (Figure 6). Observations on receiver B were concentrated on antennas 5,8 and 9 . Antenna 5 is located close to the ice-trash sluiceway outfall and antennas 8 and 9 monitor the area of the first eddies downstream of the ice-trash sluiceway outfall (Figure 6). The antennas associated with receiver $\mathrm{C}$ had varying levels of performance and are difficult to compare, however of the g-element antennas, 13 and 15 had more observations than antenna 14 (Figure 6). The two 4-element antennas 16 and 17 had a similar number of observations.

Distribution of northern squawfish over a $24 \mathrm{~h}$ period varied by antenna. Northern squawfish were recorded more often during the hours of 2100 to 0400 on antenna 3 and 1500 to 2100 on antenna 4 (Figure 7a). Observations at receiver B occurred more often in the early morning and in the afternoon at antennas 6 and 7, while recordings on the remaining antennas stayed relatively constant (Figure 7b). Within the spill basin, antennas 13 and 14 recorded an even distribution of observations over $24 \mathrm{~h}$, but antenna 15 recorded more observations as the day increased $1900 \mathrm{~h}$ 
Table 1. Summary of northern squawfish recorded by fixed receivers at The Dalles Dam, 1992.

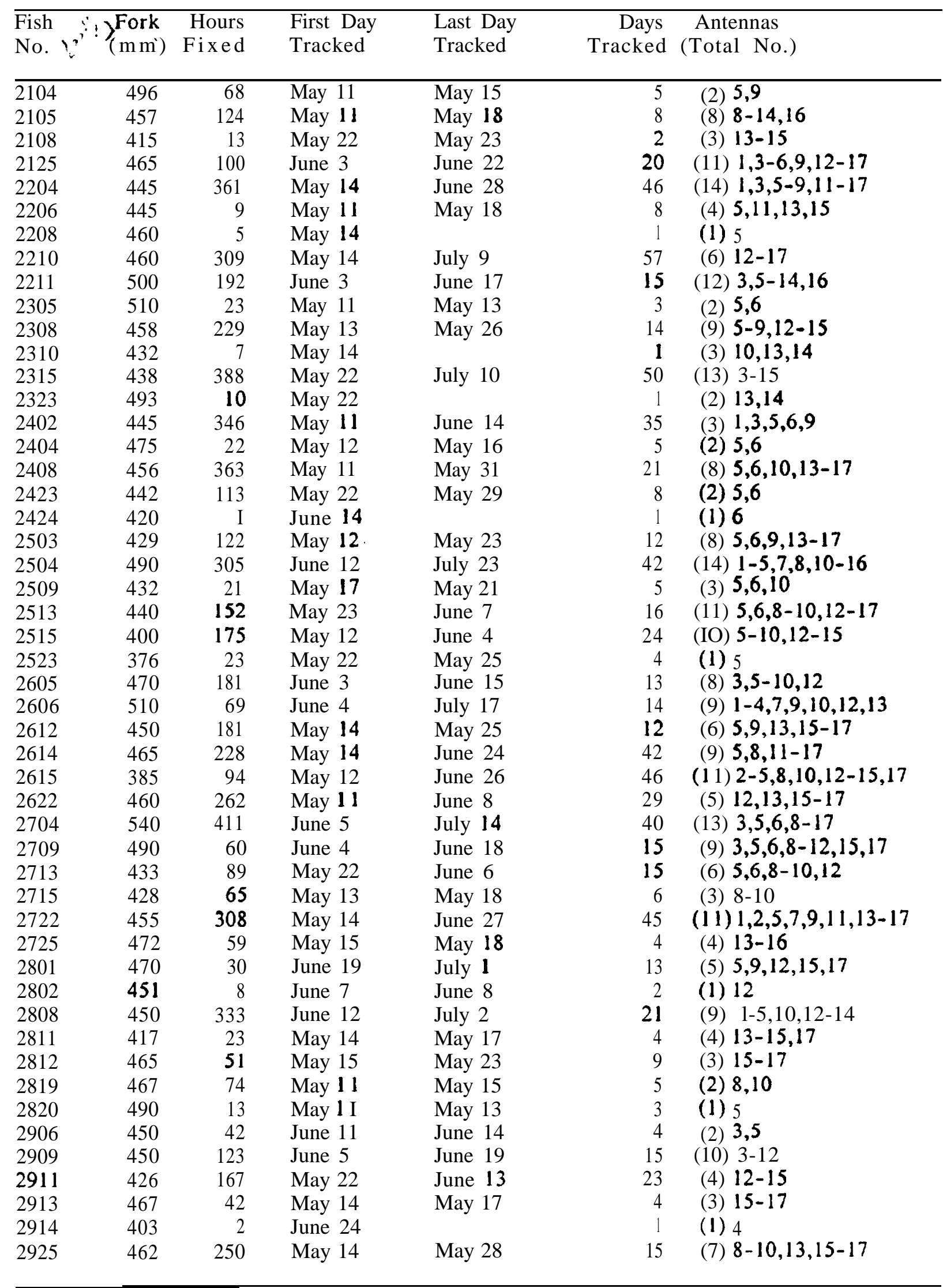



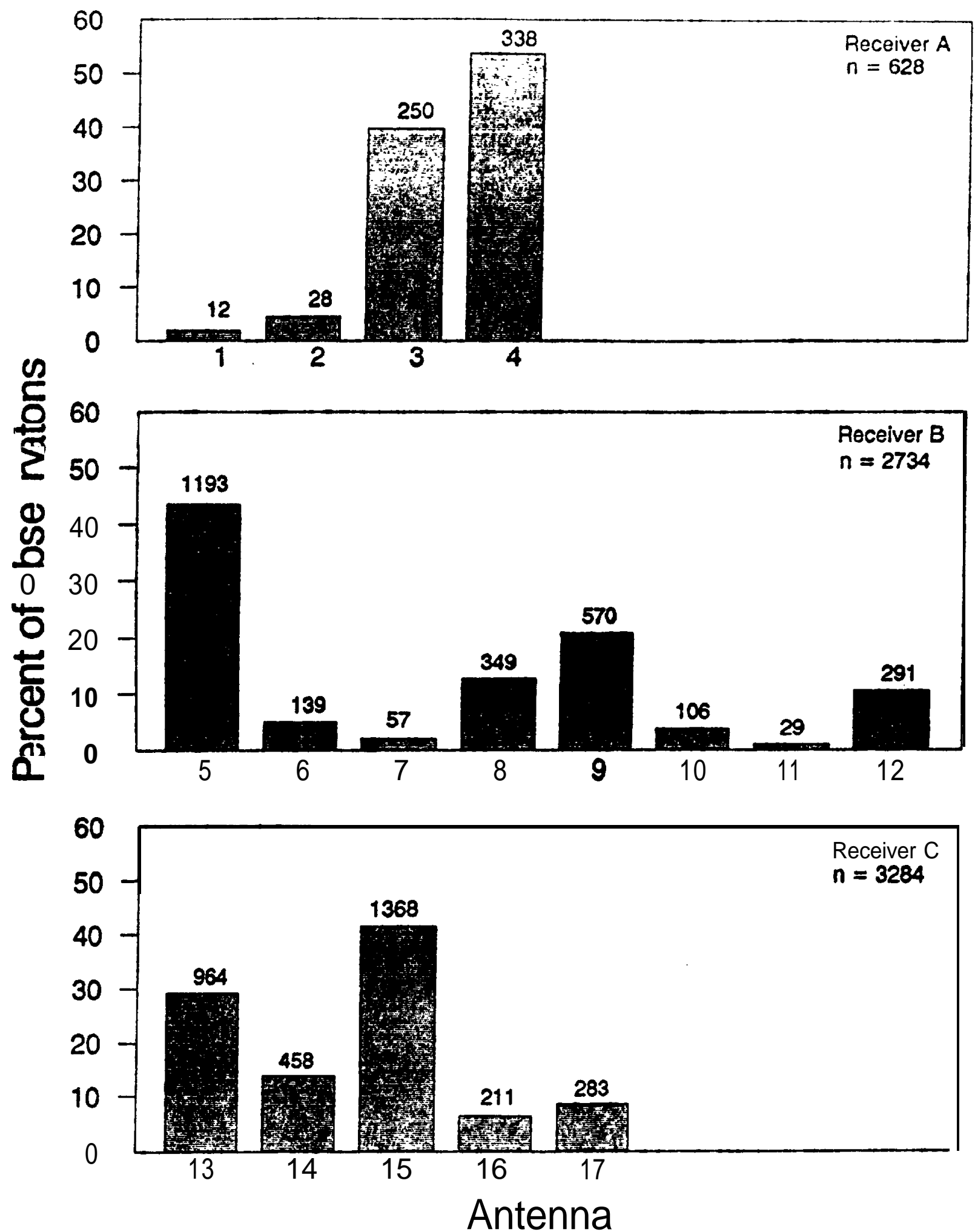

Figure 6. Percent of observations recorded on individual antennas by fixed receivers at The Dalles Dam tailrace from radio-tagged northern squawfish. See Figure 4 for location of antennas and fixed receivers. 


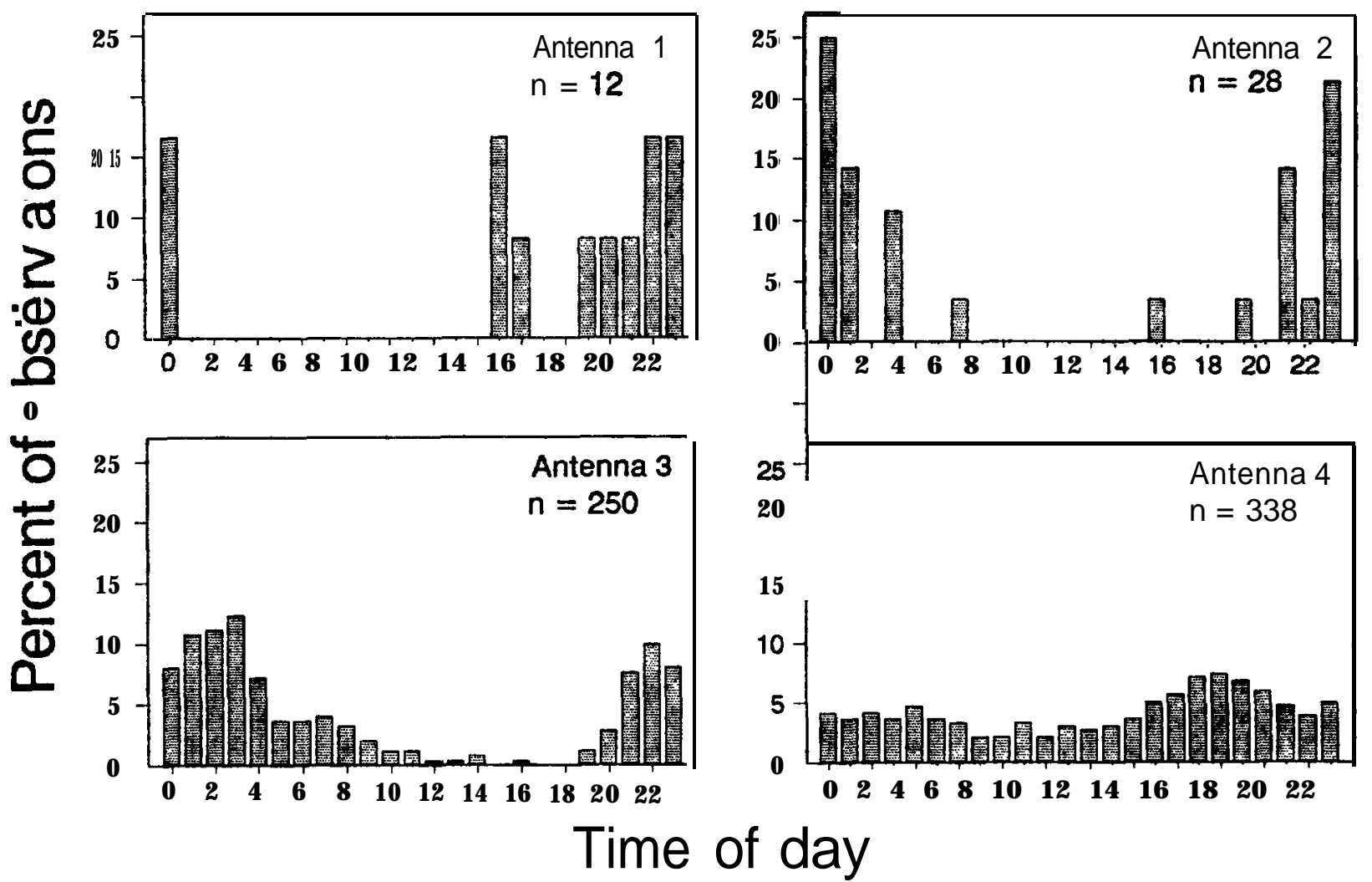

Figure 7a. Distribution of observations of radio-tagged northern squaw-fish recorded on individual. antennas at receiver A over a 24 hour period. See Figure 4 for location of antennas and receivers. 

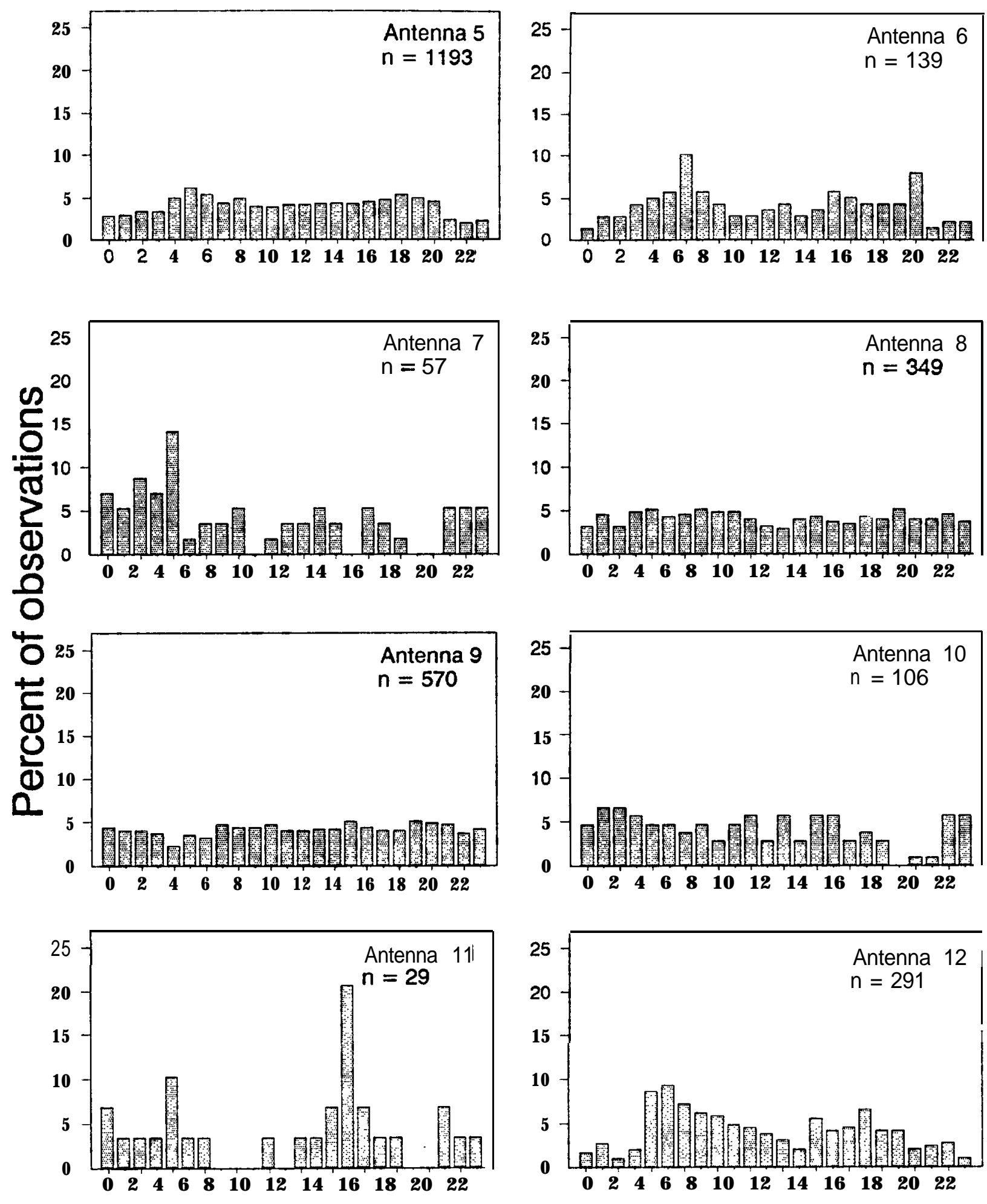

Time of day

Figure $7 \mathrm{~b}$. Distribution of observations of radio-tagged northern squawfish recorded on individual antennas at receiver B over a 24 hour period. See Figure 4 for location of antennas and receivers. 


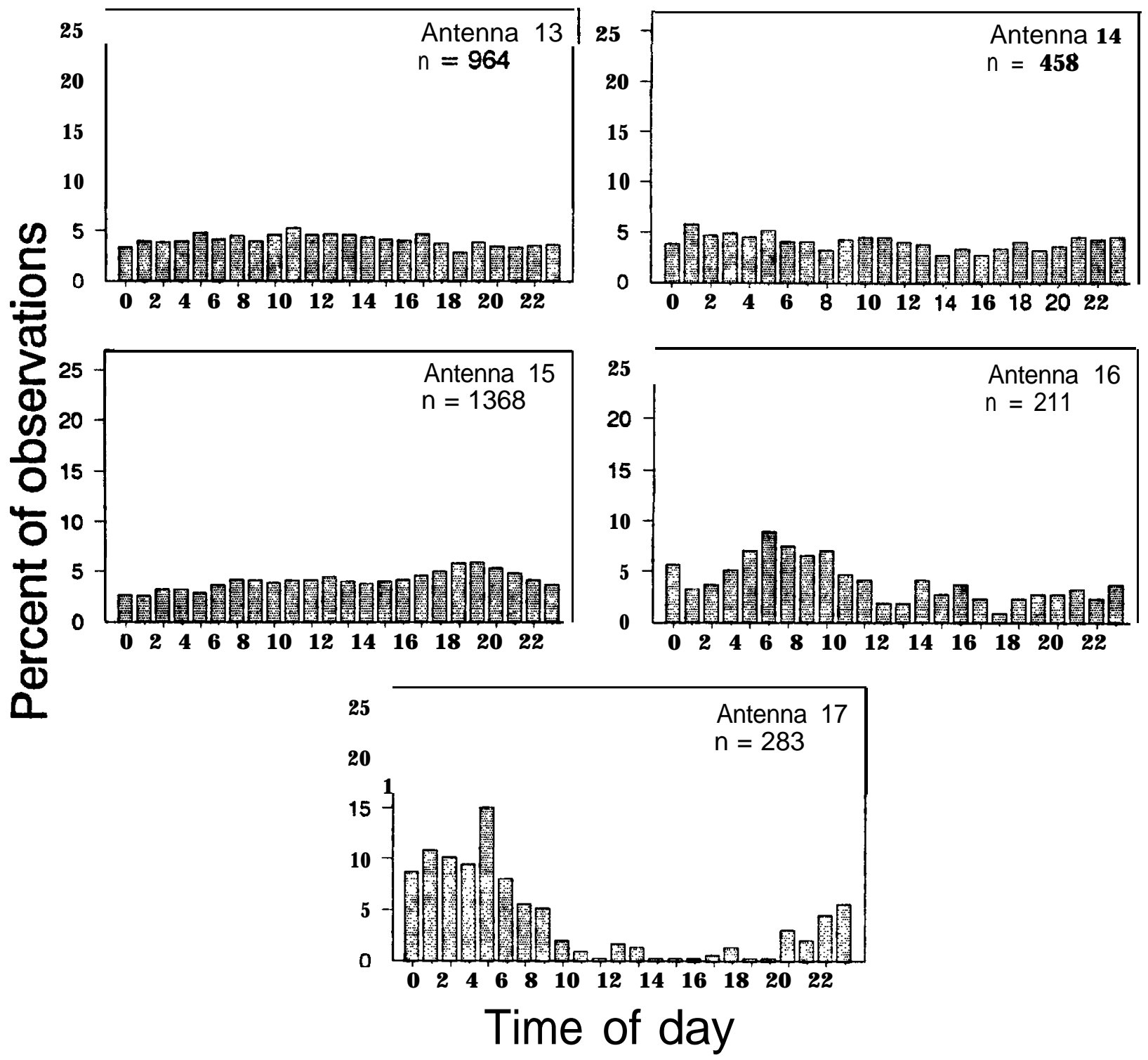

Figure 7c. Distribution of observations of radio-tagged northernsquawfish recorded on individual antennas at receiver $\mathrm{C}$ over a 24 hour period. See Figure 4 for location of antennas and receivers. 

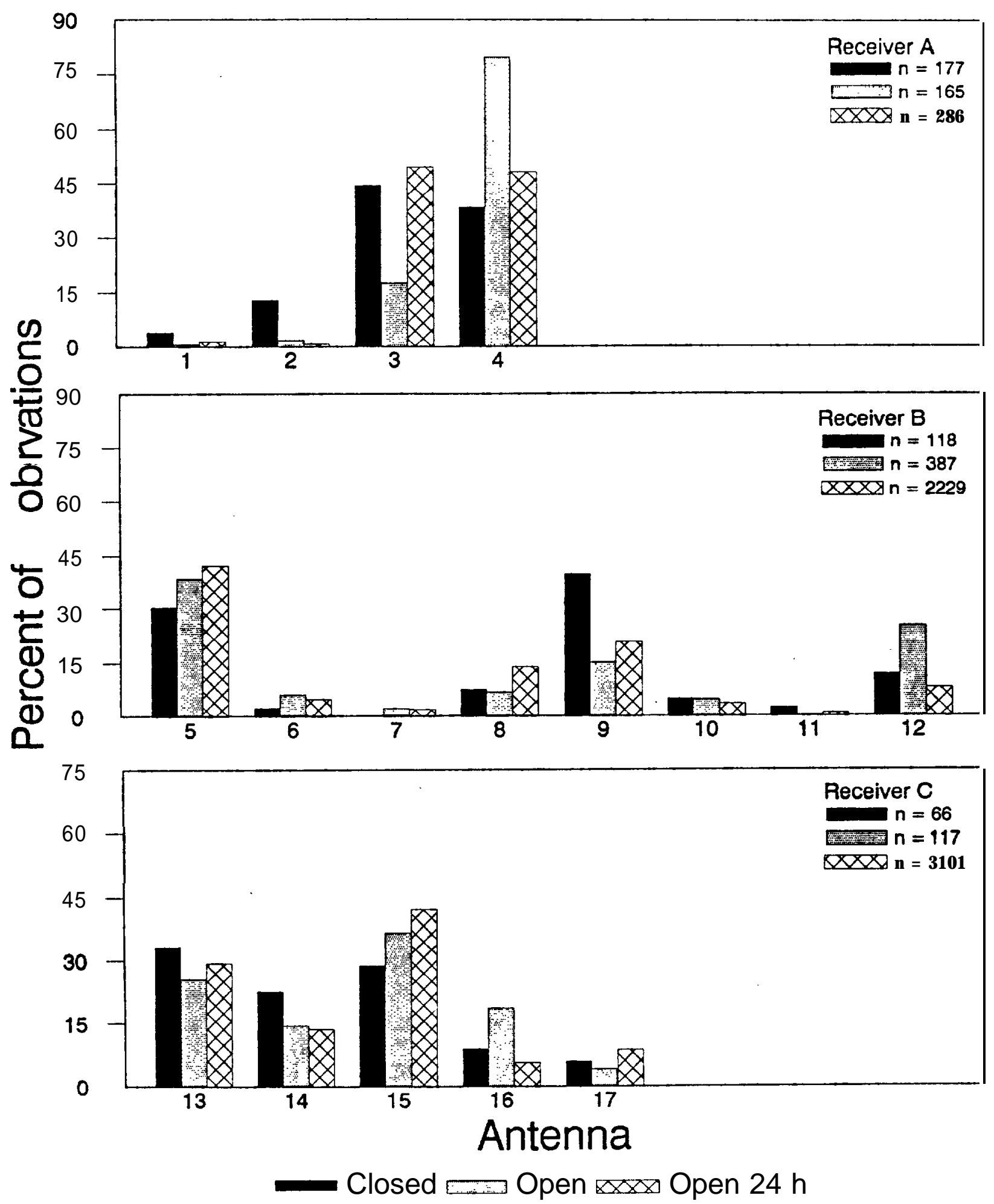

Figure 8. Percent of observations of radio-tagged northern squawfish by antenna at fixed receiver locations during different operating conditions of the ice-trash sluiceway at The Dalles Dam. The ice-trash sluiceway was open 24 hours a day from 12 May to 23 June, and 0400 to 2000 hours from 24 June to 31 August, 
and antennas 16 and 17 recorded more observations at night and in the early morning than during the day (Figure 7c).

Distribution of northern squawfish at fixed receivers varied with ice-trash sluiceway operation patterns (Figure 8 and Table 2). The area monitored by receiver B was most affected by changes in ice-trash sluiceway operation. The distribution of northern squawfish at receiver B was significantly different between the three modes of operation (open $24 \mathrm{~h}$, open, and closed). Specifically, when the ice-trash sluiceway was closed fish were most often recorded at antennas 9. When open on a schedule, antennas 5 and 12 recorded more observations, compared to antennas 5 and 9 when the sluiceway was open $24 \mathrm{~h}$. Distribution of observations at antennas 3 and 4 were similar when the ice-trash sluiceway was closed and when open 24h. However, when the sluiceway was open on a schedule, $80 \%$ of all observations at receiver A were at antenna 4 . At receiver $\mathrm{C}$, there was a significant difference in the distribution of observations when the sluiceway was open on a schedule versus periods when the sluiceway was open $24 \mathrm{~h}$. No other comparisons were significantly different (Table 2).

Distribution of northern squawfish with respect to the amount of spill was compared for each fixed receiver (Figure 9). In the area of the spill basin (receiver C) during time of no spill (0400$2000 \mathrm{~h}$ ) the majority of the observations were recorded on antennas 15 and 13. At low spill, the percentages of observations were similar at antennas 13 and 15 (28\% and 32\%). At medium spill the majority of observations were at antenna 13 and at high spill northern squawfish were recorded at antenna 15 most frequently. During spill conditions, the percent of observations also increased at antenna 17 near the tip of the navigation lock peninsula. Observations at receiver A also varied with respect to spill discharge. During periods of no spill, $73 \%$ of all observations were recorded at antenna 4. However, during times of spill more observations were recorded at antenna 3.

Distribution of northern squawfish was significantly different between all flow groups (low, medium, and high) at receivers $\mathrm{B}$ and C. Distribution at receiver A appeared not to be 
Table 2. Summary of log-likelihood ratio chi-square tests for distribution of observations at each receiver under different ice-trash sluiceway operations and amounts of spilt.

\begin{tabular}{llll}
\hline Receiver & $A^{*}$ & $B$ & $C$ \\
Dam operation
\end{tabular}

Ice-trash sluiceway

Open $24 \mathrm{hr}$ versus Open

Open $24 \mathrm{hr}$ versus Closed

Open versus Closed

Amount of spill

None versus low

None versus medium

None versus high

low versus medium

low versus high

medium versus high

$\underline{\text { Total Flow }}$

Low versus medium

Low versus high

Medium versus high

Turbine Flow

Low versus medium

Low versus high

medium versus high

$\begin{array}{lll}P<0.001 & \mathbf{P}<0.001 & \mathbf{P}<0.001 \\ \mathrm{P}=0.552 & \mathbf{P}<0.001 & \mathbf{P}=0.086 \\ \mathrm{P}<0.001 & \mathrm{P}<0.001 & \mathrm{P}=0.176\end{array}$

$\mathrm{P}<0.001$

$\mathbf{P}<0.001$

$P<0.001$

$\mathbf{P}<0.001$

$\mathbf{P}=0.281$

NA

NA

$* *$

$\mathbf{P}<0.001$

$P=0.103$
$P<0.001$
$P<0.001$
$P=0.001$
$P=0.395$
$P<0.001$

* distribution analyzed only for antennas 3 and 4.

$\mathrm{NA}=$ no data were collected from receiver A during periods of high spill discharge.

** sample size was too small for valid chi-square test. 

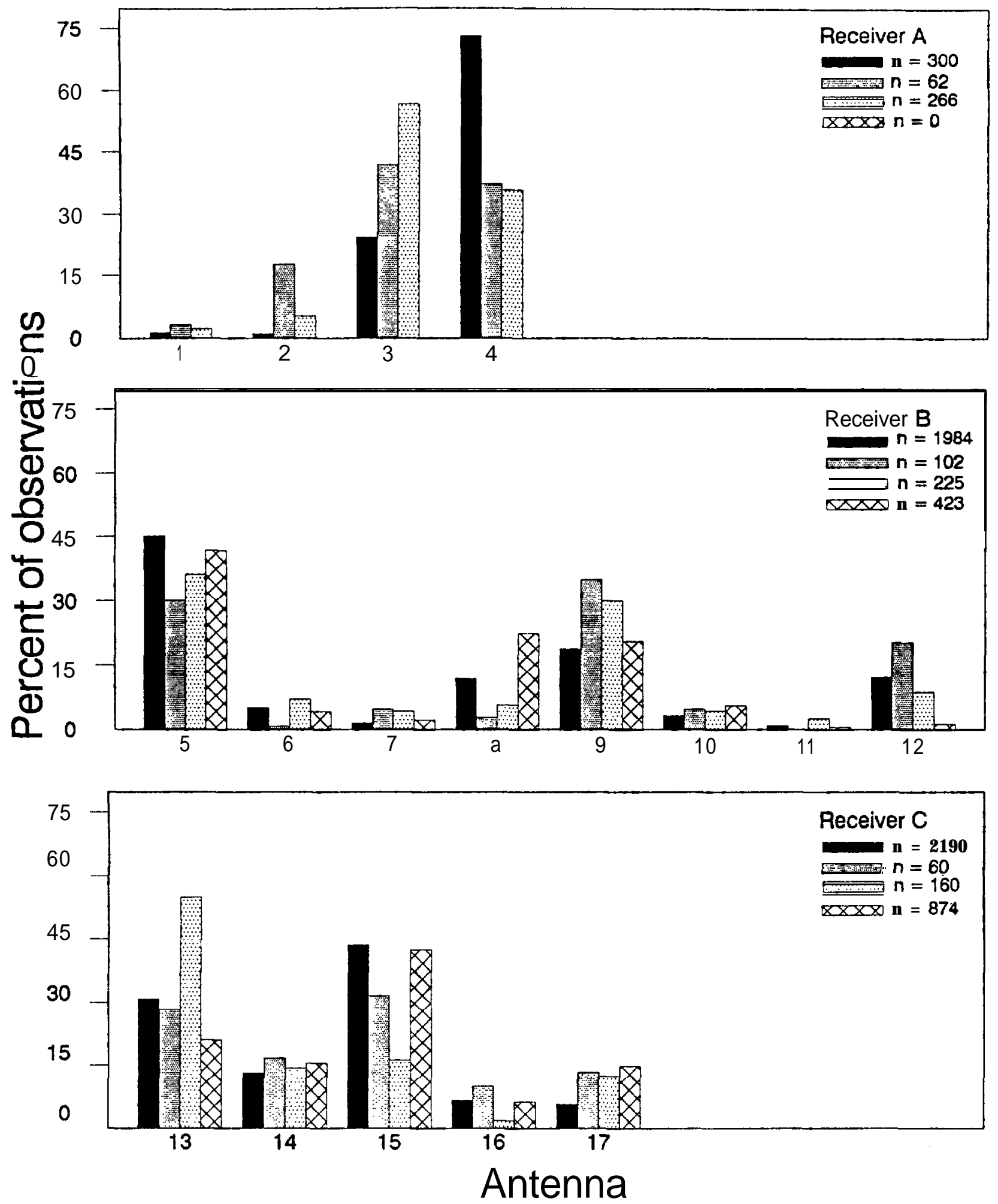

No spill $\square$ Low Medium $\times x \times>$ High

Figure 9. Percent of observations of radio-tagged northern squawfish by antenna recored at fixed receiver locations during different levels of spill discharge at The Dalles Dam (11 May to 23 July). 
significantly effected by total river flow ( $\mathrm{P}=0.277$ for all comparisons; Table 2). Distribution of observations at receiver $\mathrm{A}$ was related to high turbine flow compared to low $(\mathrm{P}=0.035$; Table 2$)$ and medium ( $\mathrm{P}=0.003$; Table 2) turbine flow. At high turbine flow, fish observations increased on antenna 4 (next to the east end of the powerhouse) and decreased on antenna 3. The length of time northern squawfish stayed at any one antenna varied (grand median $=1.4 ; \mathrm{P}<0,001$ ) and the majority of fish were not recorded for more than 1-2 continuous hours (Figures 10 a,b,c). Antennas with longer median length of stay were 4,5,8,9,13 and 15. At these antennas, northern squawfish had a high probability of being continuously recorded (Table 3). Antennas where fish moved frequently to other antennas had lower median lengths of stay. The greatest number of movements to an unknown locations or to antennas on another receiver generally occurred at antennas on the periphery of the antenna array (antennas 3, 5, II, 12, 14, and 17). When northern squawfish did move, the direction of movements were upriver at antennas 6,7 , and IO and inconclusive at other areas. 


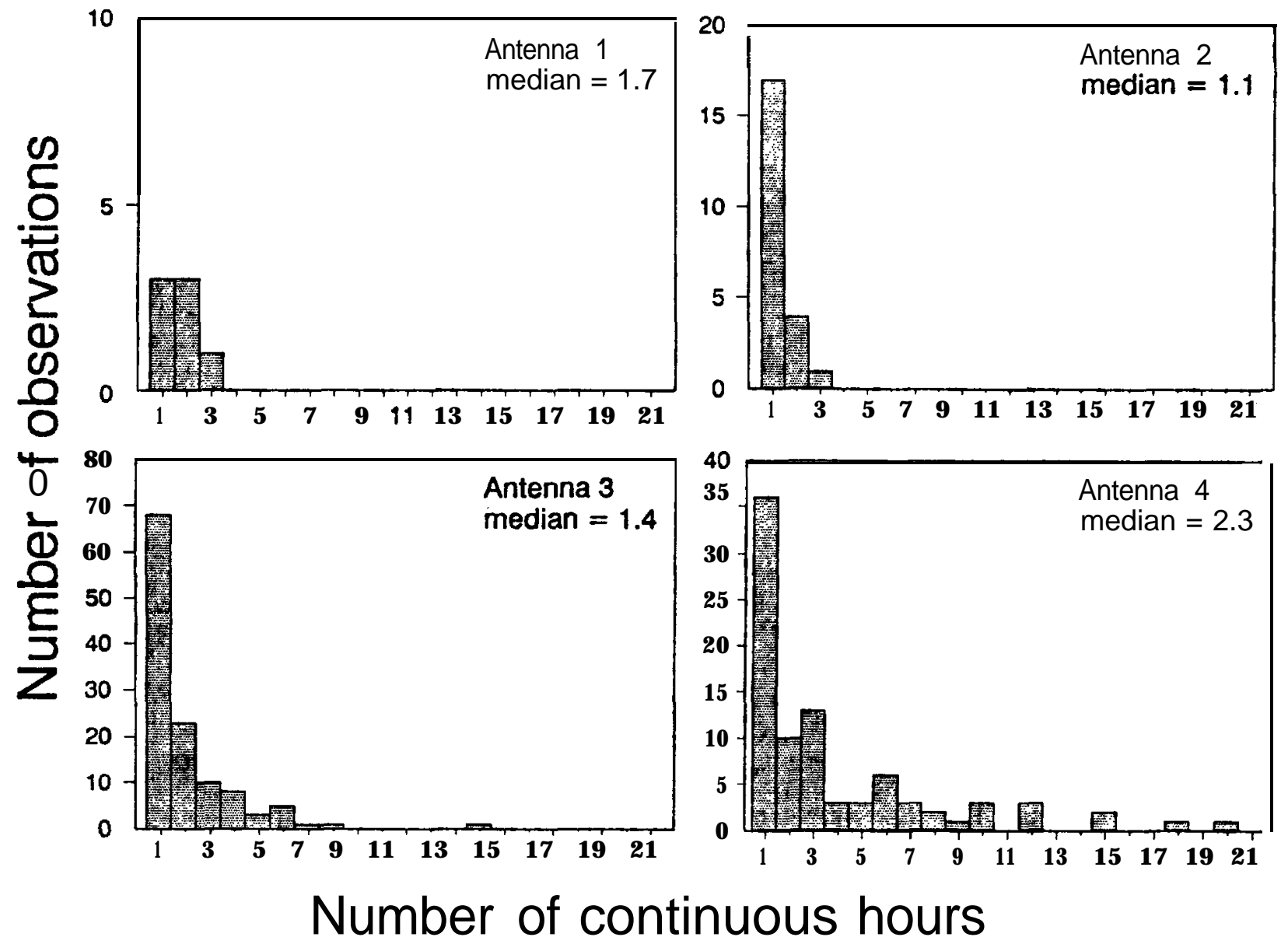

Figure $1 \mathrm{Oa}$. Frequency of continuous hours spent by radio-tagged northern squawfish at fixed receiver $\mathrm{A}$ by antenna at The Dalles Dam tailrace. 

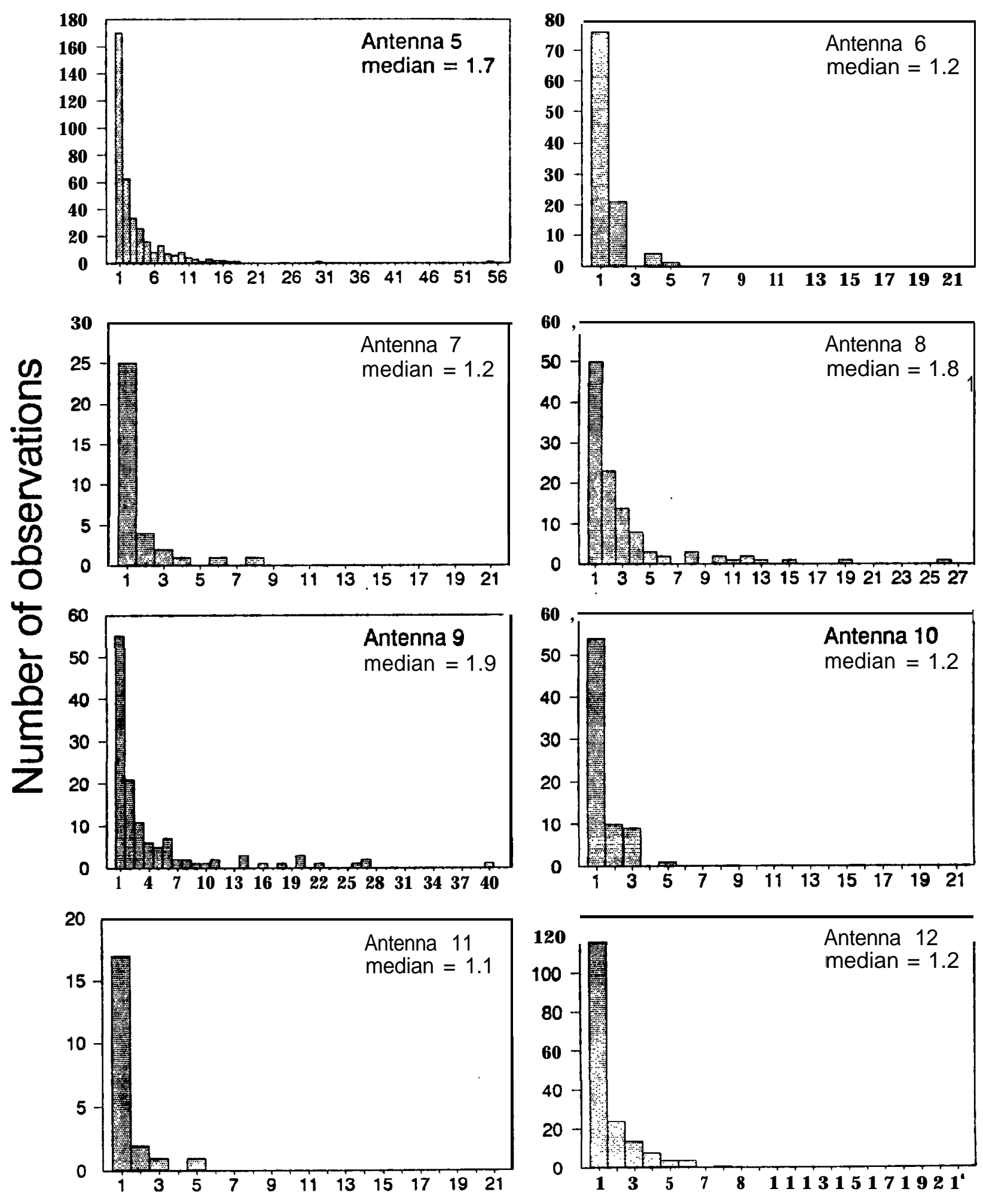

\section{Number of continuous hours}

Figure $1 \mathrm{Ob}$. Frequency of continuous hours spent by radio-tagged northern squawfish at fixed receiver $B$ by antenna at The Dalles Dam tailrace. 

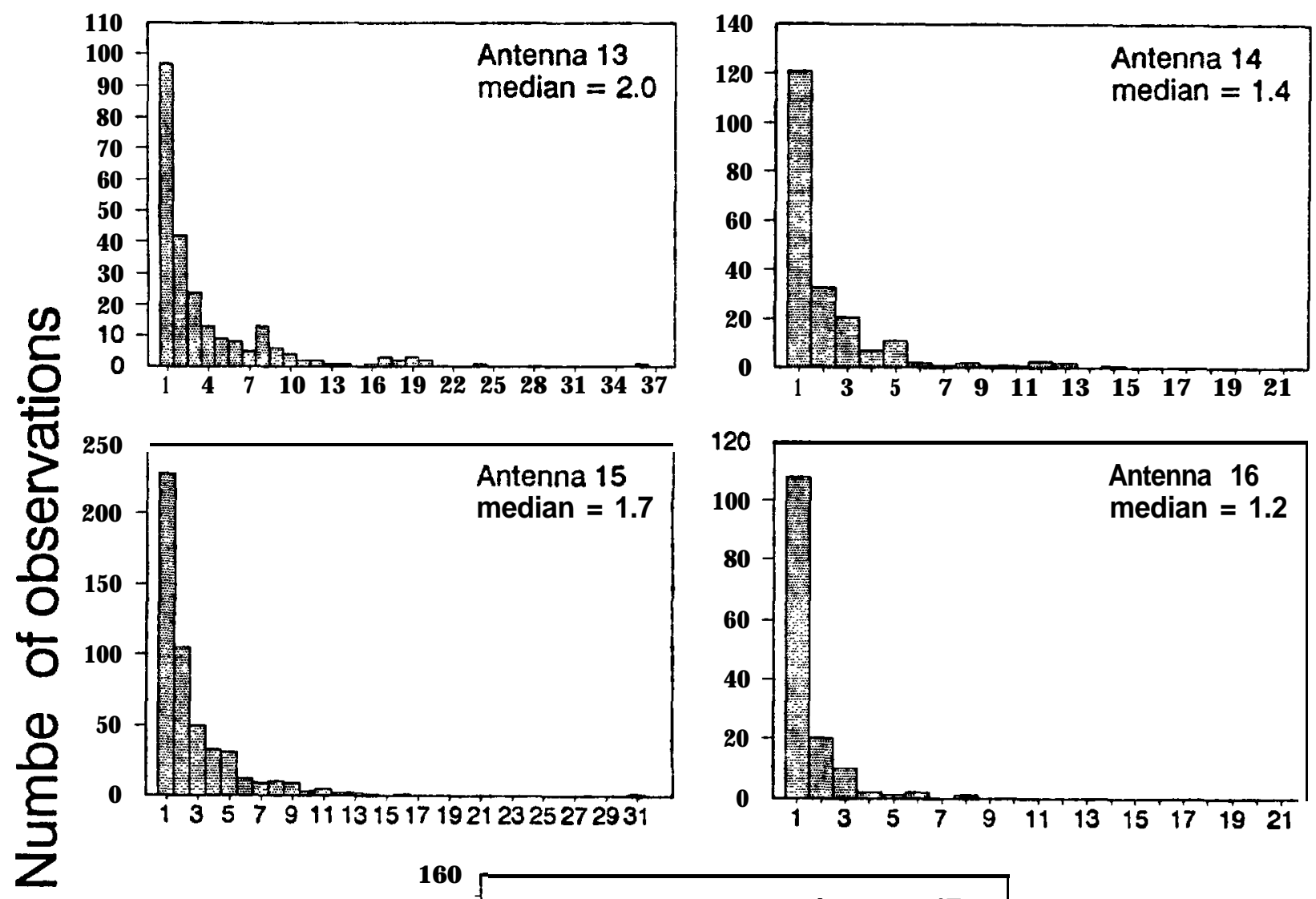

$$
80
$$$$
60
$$

$60-$

40

20

0
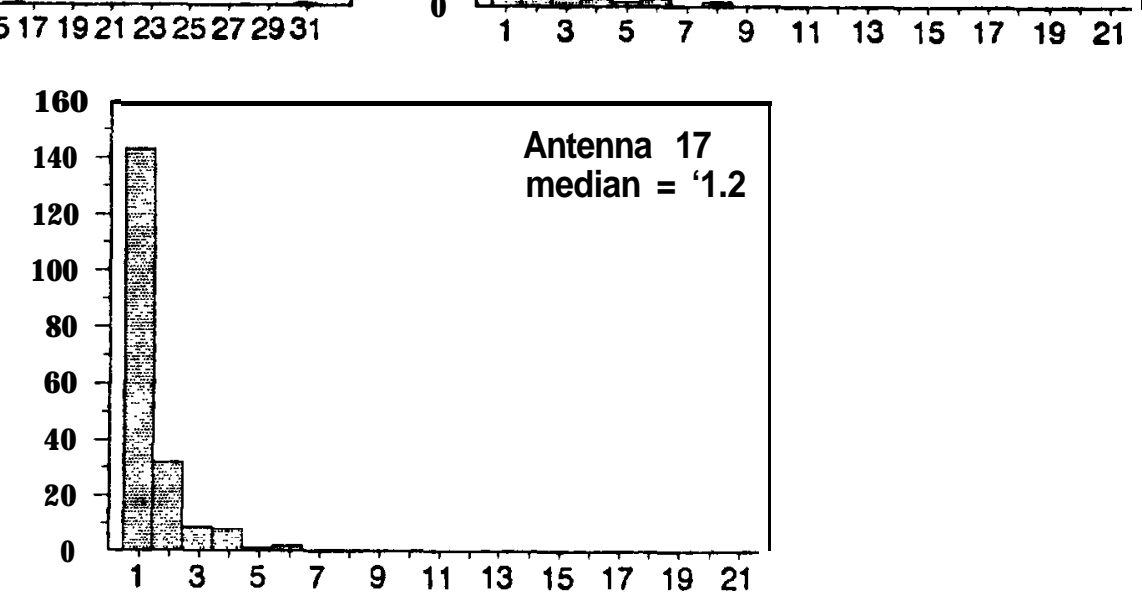

\section{Number of continuous hours}

Figure 10c. Frequency of continuous hours spent by radio-tagged northern squawfish at fixed receiver $\mathbf{C}$ by antenna at The Dalles Dam tailrace. 
Table 3. Summary of northern squawfish movement between and within antennas of the same receiver at The Dalles Dam tailrace, 1992. Other = antennas on other receivers or unknown locations.

\begin{tabular}{|c|c|c|c|c|c|c|c|c|c|}
\hline Receiver A & 1 & 2 & 3 & 4 & Other & & & & \\
\hline$\overline{1}$ & 41.8 & 8.3 & 33.3 & 8.3 & 8.3 & & & & \\
\hline 2 & 7.1 & 21.4 & 25.0 & 21.4 & 25.1 & & & & \\
\hline 3 & 0.4 & 2.4 & 52.0 & 10.0 & 35.2 & & & & \\
\hline 4 & 0.0 & 2.1 & 8.6 & 74.2 & 15.1 & & & & \\
\hline Receiver B & 5 & 6 & 7 & 8 & 9 & 10 & 11 & 12 & Other \\
\hline 5 & 69.0 & 4.0 & 0.3 & 0.8 & 1.5 & 0.3 & 0.2 & 0.1 & 23.8 \\
\hline 6 & 34.6 & 26.6 & 3.6 & 4.3 & 5.0 & 0.7 & 0.0 & 0.7 & 24.5 \\
\hline 7 & 21.1 & 3.5 & 40.3 & 7.0 & 14.0 & 0.0 & 0.0 & 1.8 & 12.3 \\
\hline 8 & 4.0 & 1.7 & 1.7 & 67.9 & 4.6 & 4.0 & 0.3 & 0.0 & 15.8 \\
\hline 9 & 1.8 & 1.2 & 2.3 & 3.9 & 77.9 & 4.2 & 0.7 & 3.3 & 4.7 \\
\hline 10 & 2.8 & 0.9 & 0.9 & 18.9 & 25.5 & 30.3 & 0.9 & 2.8 & 17.0 \\
\hline 11 & 6.9 & 3.5 & 0.0 & 3.5 & 10.3 & 0.0 & 27.6 & 13.8 & 34.4 \\
\hline 12 & 1.0 & 1.4 & 0.0 & 1.0 & 3.4 & 1.0 & 1.0 & 40.9 & 50.3 \\
\hline Receiver C & 13 & 14 & 15 & 16 & 17 & Other & & & \\
\hline 13 & 75.1 & 5.5 & 0.9 & 0.2 & 0.0 & 18.3 & & & \\
\hline 14 & 12.7 & 55.0 & 2.8 & 0.4 & 0.0 & 29.1 & & & \\
\hline 15 & 0.2 & 1.0 & 63.3 & 7.2 & 5.9 & 22.4 & & & \\
\hline 16 & 1.0 & 1.0 & 45.3 & 31.8 & 2.4 & 18.5 & & & \\
\hline 17 & 0.4 & 0.0 & 25.8 & 3.9 & 31.1 & 38.8 & & & \\
\hline
\end{tabular}




\section{DISCUSSION}

Fixed receiver sites were established to monitor distribution and movement of tagged northern squawfish near proposed bypass outfall sites and other areas within TDA BRz. Due to the high rate of transmitter failure we were limited in our ability to make definite conclusions regarding northern squawfish behavior at TDA tailrace. However, sufficient data was collected in the first year of this study to indicate that fixed site receivers with aerial yagi antennas can be an effective method to monitor behavior of northern squawfish in localized areas. We were able to monitor general movements and distributions of northern squawfish as well as identify areas of frequent use. The distributions and movements of northern squawfish varied with regard to project operation and time of day at TDA tailrace area. In particular, operation of the ice-trash sluiceway and spill gates appeared to influence northern squawfish movements and distribution at The Dalles Dam.

Because of differences between fixed receiver sites due to system configuration, areas of coverage, and time of operation, it is inappropriate to directly compare the frequency of observations between receivers. Therefore, we limited our analyses to the antennas on each receiver. Antennas that recorded the most observations monitored areas where at least one high water velocity area was bordered by a low velocity area. At receiver A, the vast majority of observations were recorded near the powerhouse on antennas 3 and 4 and some mobile tracking data indicated that fish were located about $50-100 \mathrm{~m}$ from the turbine discharge in an area of low water velocity. In the area of the ice-trash sluiceway (receiver B), northern squawfish were recorded most frequently in the area of the sluiceway outfall (antenna 5) and the first downstream eddy (antennas 8 and 9). In the spill basin, antennas 13 and 15 recorded the most activity. These antennas are capable of .monitoring northern squawfish movements in the area near the rock islands. This area was identified by Clugston and Schreck (this report) as being an area where juvenile salmonids held after experimental releases from the vicinity of the ice-trash sluiceway. 
Considering the frequency of observations by time of day is complicated because project operations (e.g. spill and sluiceway discharge) usually occur on a schedule. Therefore, any patterns of behavior noted may be confounded with project operations. Time of day could be important with regard to northern squawfish diel consumption patterns of juvenile salmonids (Vigg et al. 1991) and increased passage of juvenile salmonids at night (Long 1969, Gessell et al. 1986, and Johnson et al. 1986).

At The Dalles Dam, we noted increases in the number of observations during early morning and evening hours at antennas near the powerhouse (antenna 3), ice-trash sluiceway outfall (antenna 6 and 7), and navigational lock peninsula (antennas 16 and 17). Some of the increase in activity may be due to project operation (e.g. increase in observations at antennas 16 and 17 may be directly attributable to spill), while at other sites (e.g. ice-trash sluiceway outfall) the peaks may be attributed to project operations and environmental changes (e.g. juvenile salmonids passing through the dams). In either case, we did not collect sufficient data to determine the effect of time of day for the observed movements and distributions. However, within specific areas we were able to obtain detailed information on northern squawfish movements.

In the area of the ice-trash sluiceway northern squawfish were monitored by receiver B (antennas 5-12). Northern squawfish were most often recorded near the outfall of the ice-trash sluiceway (antenna 5) and the first downstream eddy (antennas 8 and 9). This was consistent with Columbia River Inter-Tribal Fish Commission's dam angling catches (Blaine Parker, pers. comm.) and USFWS consumption index sampling (USFWS, unpubl. data). When the ice-trash sluiceway was open (either $24 \mathrm{~h}$ or on a schedule) northern squawfish were recorded in the vicinity of the outfall more frequently than when it was closed. Northern squawfish most likely congregate in this area due to the attraction of flow and the abundance of juvenile salmonids. During a hydroacoustic evaluation of juvenile salmonid passage at The Dalles Dam in 1986, 36\% of the total number of juvenile salmonids passed through the ice-trash sluiceway (Johnson et al. ). Northern 
squawfish also were commonly recorded in the areas of the first eddy downstream from the sluiceway w.hen the sluiceway was open, but when the sluiceway was closed the percent of observations increased. By examining individual movement records of fish recorded on receiver B when the sluiceway was operated $24 \mathrm{~h} / \mathrm{d}$, we noted some fish frequently moved directly from the outfall to the eddy and vice versa. We had few detailed individual histories when the sluiceway was on a schedule (due to tag failure), though we did observe some fish responding to opening and closing of the sluiceway. When the sluiceway was open, fish were often recorded near the outfall, when closed, fish generally moved to another area and return once the sluiceway was re-opened. Due to the few number of functioning transmitters at the time the sluiceway was operating on a schedule we can not estimate the average amount of time it took northern squawfish to respond to operations of the sluiceway.

The. spill basin was monitored by receiver $\mathrm{C}$ (antennas 13-17) and was larger than the areas monitored by receivers $\mathrm{A}$ and $\mathrm{B}$. Therefore, we are less certain where fish were located when recorded in this area. The majority of activity was recorded immediately below the spill gates (antenna 13) and the area of the rock islands and highway bridge (antenna 15). During mobile tracking in the tailrace area, northern squawfish were sometimes located in the area below the rock islands and recorded on antenna 15 at similar times.

Northern squawfish appeared to respond variably to spill discharge in The Dalles Dam tailrace. During times of no spill, northern squawfish were most often recorded at antenna 15, and at a lesser frequency at antenna 13. When spilling occurred, fish were distributed differently at varying levels of spill. The percent of observations typically decreased at antennas 13 and 15 at times of spill. However, under certain conditions northern squawfish activity increased in these areas. When northern squawfish were recorded on antenna 13 during times of spill it is.possible these fish may be selecting areas of reduced flows at the edge of spill discharge. However, until we obtain individual locations on fish we are unable to say for sure where these fish are located within the area covered by this antenna. The location of fish recorded at antenna 15 is also 
difficult to determine, however mobile tracking data did indicate that northern squawfish were located to the west of the rock islands near the highway bridge. These trends may have been due to the amount of spill discharge or related to time of year. Periods of high spill discharge occurred early in the season (May), and spill discharge decreased over time. Regardless of the level of spill discharge, when spill occurred, the percent of observations increased at antenna 17. This antenna monitored a large eddy downstream of the navigational lock peninsula. A typical individual response of northern squawfish to spill was to move downriver once spilling began and this would account for the increased observations at antenna 17.

We also noted trends in northern squawfish distribution at other receiver locations during different spill conditions. Specifically during times of no spill, northern squawfish were located near the turbine outflow at antenna 4. Once spilling occurred, observations increased at antenna 3. We were not able to obtain specific information regarding turbine operation in this area but we suspect the observed movements could be attributable to turbine units being shut down or decreased juvenile salmonid passage.

In addition to obtaining location data, we wanted to determine response times and movement data for northern squawfish. We attempted to quantify movement of northern squawfish with several measures. We calculated the median amount of time a fish was recorded at a particular antenna location. This provided a measure of time spent at certain antennas as well as give us an indication of how well the telemetry system was performing. In most instances we do not have $24 \mathrm{~h}$ continuous records on fish movements. On average we generated about 8 observations per day per fish with median times of coverage at any one antenna between 1-2 $\mathrm{h}$. However, some fish were recorded continuously from the same antenna or combinations of antennas for over $24 \mathrm{~h}$.

When we examined records from fixed receivers where we had two or more hours of continuous coverage on a particular fish, we were able to estimate the probability of a fish moving to other antenna locations or remaining at the same location. These probabilities are conservative 
because we only examined records where we had continuous data. If there was an interruption of coverage we assumed the fish moved to the "other" category, even though coverage may have resumed at the same antenna location several hours later with no record of the fish at any other antenna locations. Still we were able to identify areas where northern squawfish were likely to stay for several hours at time before moving and identify the direction of movement. It is not surprising the antenna locations that recorded the most observations were those that northern squawfish tended to remain at for longer periods of time. The east end of the powerhouse outflow, ice-trash sluiceway outfall, downstream eddy of ice-trash sluiceway, and spill basin were areas where northern squawfish were likely to spend several hours before moving. When northern squawfish did move, they were most likely to move the distance of I-2 antennas at a time. Based on some individual records, there were some dramatic movements between antennas, however these movements seemed limited. However, we have insufficient data at this time to estimate the average distance northern squawfish moved and at what rate this movement occurred.

Results from TDA tailrace indicate that northern squawfish movements and distribution varied with respect to changes in project operation and time of day. In 1993, we plan to increase mobile tracking efforts to obtain more precise location information to supplement data collected by fixed receivers. With this information we hope to identify habitat characteristics of areas where northern squawfish are likely to be located. Also, we will stratify periods of sampling to obtain data on how northern squawfish respond to changes in project operation (e.g. ice-trash sluiceway and spill discharge). Information concerning predator response and the amount of time it takes for the response to occur could be very important to the design and operation of JBS. In 1993, we will expand our area of study to include the John Day Dam tailrace and JBS outfall to determine how northern squawfish respond and are distributed in a dam tailrace with an existing JBS. 


\section{REFERENCES}

Clugston, D.A. and C.B. Schreck. This report. Movement, distribution, and behavior of juvenile salmonids passing through Columbia and Snake River Dams, 1992. Annual report of research in .... T.P. Poe ed.

Faler, M.P., L.M. Miller, and K.I. Welke. 1988. Effects of variation in flow on the distribution of northern squawfish in the Columbia River below McNary Dam. North American Journal of Fisheries Management, 8:30-35.

Gessell, M.H., L.G. Gailbreath, W.D. Muir, and R.F. Krema. 1986. Evaluation of the juvenile collection and bypass systems at Bonneville Dam-1985. Annual Report (contract DACW57-85-H-,0001) to U.S. Army Corps of Engineers, National Marine Fisheries Service, Seattle, Washington.

Johnson, R.C., L.A. Wood, W.W. Smith. 1986. Monitoring of downstream salmon and steelhead at federal hydroelectric facilities-1986. Annual Report (contract DE-AI-79-85BP20733) to Bonneville Power Administration, National Marine Fisheries Service, Seattle, Washington.

Johnson, W.R., L. Johnson, and D.E. Weitkamp. 1987. Hydroacoustic evaluation of the spill program for fish passage at The Dalles Dam in 1986. Report of research, prepared for the U.S. Army Corps of Engineers, Portland District, Portland OR, 68pp.

Long, C.W. 1968. Die1 movement and vertical distribution of juvenile anadromous fish in turbine intakes. U.S. Fish and Wildlife Service Fishery Bulletin 66:599-609.

Mesa, M.G. and T.M. Olson. In press. Prolonged swimming performance of northern squawfish: can water velocity be used to reduce predation on juvenile salmonids at Columbia River dams? Transactions of the American fisheries Society, 122:000-000.

Poe, T.P., H.C. Hansel, S. Vigg, D.E. Palmer, and L.A. Prendergast. 1991. Feeding of predaceous fishes on out-migrating juvenile salmonids in John Day Reservoir, Columbia River. Transactions of the American Fisheries Society, 120: 405-420.

Rieman, B.E., R.C. Beamesderfer, S. Vigg, and T.P. Poe. 1991. Estimated loss of juvenile salmonids to predation by northern squawfish, walleyes, and smallmouth bass in John Day Reservoir, Columbia River. Transactions of the American Fisheries Society, 120: 448-458.

Vigg, S., T.P. Poe, L.A. Prendergast, and H.C. Hansel. 1991. Rates of consumption of juvenile salmonids and alternative prey fish by northern squawfish, walleyes, smallmouth bass, and Channel Catfish in John Day Reservoir, Columbia River. Transactions of the American Fisheries Society, 120:421-438. 
Walpole, R.E. and R.H. Myers. 1985. Probability and statistics for engineers and scientists, 3rd edition. Macmillan Publishing Company, New York.

Zar, J.H. 1984. Biostatistical Analysis, 2nd edition. PrenticeHall, Englewood Cliffs, New Jersey. 


\title{
Report 6
}

\section{Movement Distribution, and Behavior of Juvenile Salmonids Passing Through Columbia and Snake River Dams, 1992}

\author{
David A. Clugston (Project Leader) \\ and \\ Carl B. Schreck (Principal Investigator)
}

Oreaon Cooperative Fishery Research Unit, Oregon State Universitv. 104 Nash Hall, Corvallis, OR 97331 


\section{EXECUTIVE SUMMARY}

Steelhead and chinook smolts were equipped with radiotags and released at the two proposed outfall sites, one of which will be where The Dalles Dam's new juvenile bypass system outfall will be built. These fish were then tracked to determine which release site would move smolts downstream the fastest while avoiding areas of high predation risk.

Results from this preliminary field season show that radiotagged juvenile salmonids can be tracked in tailrace outfall areas to determine how fast they disperse, where and for how long they hold, and the outmigration routes traveled under different operating and river conditions.

Limited data on chinook smolt dispersal indicates a slower outmig ration rate with a greater variety of outmigration routes across the Columbia River when compared to steelhead smolts. Results from 1993 should clarify differences between the species.

For the set of conditions we tested this year steelhead smolts released at the upstream potential bypass outfall dispersed significantly slower than steelhead smolts released at the downstream potential bypass outfall. Upstream released fish also took significantly less time to reach their first holding site (an area of the river where a fish stopped its outmigration and moved less than 400 meters for at least $30 \mathrm{~min}$ ) than did downstream released fish, 11 .I and $39.0 \mathrm{~min}$, respectively. The major holding area for upstream released smolts was less than $0.8 \mathrm{~km}$ from where they were released, in an area of suspected high predator concentration.

Over a third $(37 \%)$ of all radiotagged steelhead smolts stopped their outmigration and held in place somewhere in the study area after being released. Downstream released fish were just as likely to hold as upstream released fish. However, downstream released fish had further to travel and thus more time to recover, before reaching their first major holding area. Fish given an additional stress treatment before release at either site were nearly twice as 
likely to hold ( $45 \%$ vs. $26 \%$ ) as were the control fish that were not given additional stress treatments.

The location of release and whether or not a fish was additionally stressed may influence the likelihood of being consumed by a predatory fish. Of the 5 steelhead smolts that we suspect may have been preyed upon, 3 were stressed and released upstream, one was stressed and released downstream, and one was released upstream with no additional stressing.

A smaller transmitter (cylindrical, $15 \mathrm{~mm}$ long $\times 7 \mathrm{~mm}$ diameter) was procured and field tested. It preformed nearly equal to last years transmitters. Preliminary results of stomach implantation survival tests indicate that chinook salmon with forklengths down to approximately $120 \mathrm{~mm}$ can be safely implanted with this newly designed transmitter. 


\section{INTRODUCTION}

A major problem facing outmigrating juvenile salmonids is the stress, injury, and mortality possible during passage through and just below dams. Designs of juvenile bypass systems (JBS) and dam operations have been and continue to be modified to help facilitate passage. Early modifications were based primarily on modeling and flow studies, hydroacoustic monitoring of juvenile fish at dam entrances, and examination of fish condition and counts at various sites within the JBS. Very little testing has been done to evaluate the effectiveness of design and operation changes on the outcome and behavior of smolts immediately after passing through the dams.

The objectives of this study were to develop techniques and methodology to enable us to radiotrack outmigrating smolts in the tailrace area of The Dalles Dam and to evaluate which of the two proposed juvenile bypass outfall sites best moves smolts downstream. We also planned to investigate what effects different levels of stress might have on the outmigration and dispersal behavior of these fish.

One of the problems we needed to overcome was to develop a radiotracking scheme that would work following small fish in the tailrace area of a major dam in a large river system. Earlier radiotelemetry work on the Columbia River, primarily by the National Marine Fisher\&es Service (NMFS) in the mid 1980s, determined that radiotagged chinook smolts behaved similarly to other non-tagged smolts and that telemetry could be used to assess spill efficiency and estimate where juveniles passed through the dams (Giorgi et. al., 1983; Giorgi et. al., 1985; Stuehrenberg et. al., 1986; Giorgi et. al., 1988). Very little of their work focused on the tailrace areas. Only Giorgi et. al. (1988) and Stier and Kynard (1986) tracked in the tailrace areas, undertaking transect searches for fish after they passed through dams to determine if they could tell if the fish were dead or alive. Giorgi et. al. (1988) could not differentiate between dead or living smolts, Stier and Kynard (1986), could. 
One of the major reason people became more concerned with the tailrace areas and the behavior and condition of juvenile fish after passing through dams was the problem of increasing numbers of predatory fish found in the Columbia River, especially in the vicinity of dams. Poe et. al. (1991) and Viggs et. al. (1991), discovered that large numbers of smolts were being consumed by predatory fish, primarily northern squawfish. Maule (1988) showed that passage through dams in general, and through JBS in particular, is stressful to fish. Mesa (1992) found that chinook juveniles that were given an agitation stress treatment were more susceptible to predation by northern squawfish. Their work pointed to the importance of the area just below dams and the condition of smolts immediately after passage, and began to explain some of the unexplained losses of juvenile saimonids between dams.

The NMFS undertook the only extensive study on juvenile salmonid mortality and outmigration in any tailrace area, below Bonneville Dam. Their evaluation of direct mortality caused by the juvenile bypass system along with their long term survival study of smolts released at various sites at Bonneville dam and sampled at Jones Beach illuminated the difficulties involved with trying to pinpoint the problems associated with a JBS. They found that smolts released through the JBS had surprisingly low recapture rates at Jones Beach, nearly the same as smolts released through the turbine units. However, direct mortality measurements at the JBS outfall were also very low (Ledgerwood et.al., 1991). This seems to indicate that most of the problem with smolt mortality lies downstream of the immediate outfall sites in the tailrace area.

Our work, in conjunction with the United States Fish and Wildlife Service (USFWS) study on the distribution and movement patterns of northern squawfish in The Dalles Dam tailrace via radiotelemetry, was a logical next step in determining the outcome of smolts after passing through dams. By following radiotagged smolts downstream of the proposed outfall sites in the tailrace we can examine their dispersal behavior, where they hold, how fast they outmigrate, their relationship to locations of known predators and how these variables change with differences in stress, river conditions, or dam operations. By better understanding these factors we can begin to determine which 
locations and operations will best pass smolts to minimize predator-related mortality as well as gather important information on general smolt outmigration biology.

\section{MATERIALS AND METHODS}

During the spring field season we evaluated the dispersal behavior of six releases of radio-tagged smolts in the tailrace area of The Dalles Dam. The study area consisted of the section of the Columbia River from The Dalles Dam downstream to river marker "66" approximately 3 miles below The Dalles bridge (Figure 1). We released three of the groups in the vicinity of one of the two the proposed bypass outfall, near mid channel 100 meters downstream of the sluiceway. This site is referred to as the "upstream" outfall location. The other three releases occurred in the vicinity of the other proposed bypass outfall on the south side of the navlock peninsula approximately 50 meters downstream of The Dalles bridge (Figure 2) hereafter referred to as the "downstream" outfall location. The first two releases were primarily used to evaluate methods of transporting fish to the release site, the exact location of the release sites, the datalogging system, and boat tracking techniques.

Half of each release group underwent a stress treatment. The other half was untreated and used as controls to look for differences in smolt dispersal behavior related to differences in the amount of stress they experience before release.

In order to obtain river run, hatchery-released smolts and to coordinate with other smolt sampling and tracking being undertaken by Oregon State Univerisity researchers, we arranged to capture and tag smolts at Lower Granite dam and have them transported by barge to The Dalles Dam.

Smolts to be radiotagged were netted just above the separator at Lower Granite Dam and immediately anesthetized in a $2 \mathrm{ml}$ per liter Tricaine methanesulfonate (MS-222) and $\mathrm{NaCH03}$ buffer solution. Fish were weighed; measured to determine forklengths; equipped with a $22 \times 11 \times 10 \mathrm{~mm}, 3.0 \mathrm{~g}$, stomach implanted, Lotek (model) radiotransmitter; and put into a recovery 
FIGURE 1: Smolt Dispersal Study Area. The Columbia River from The Dalles Dam to marker "66"

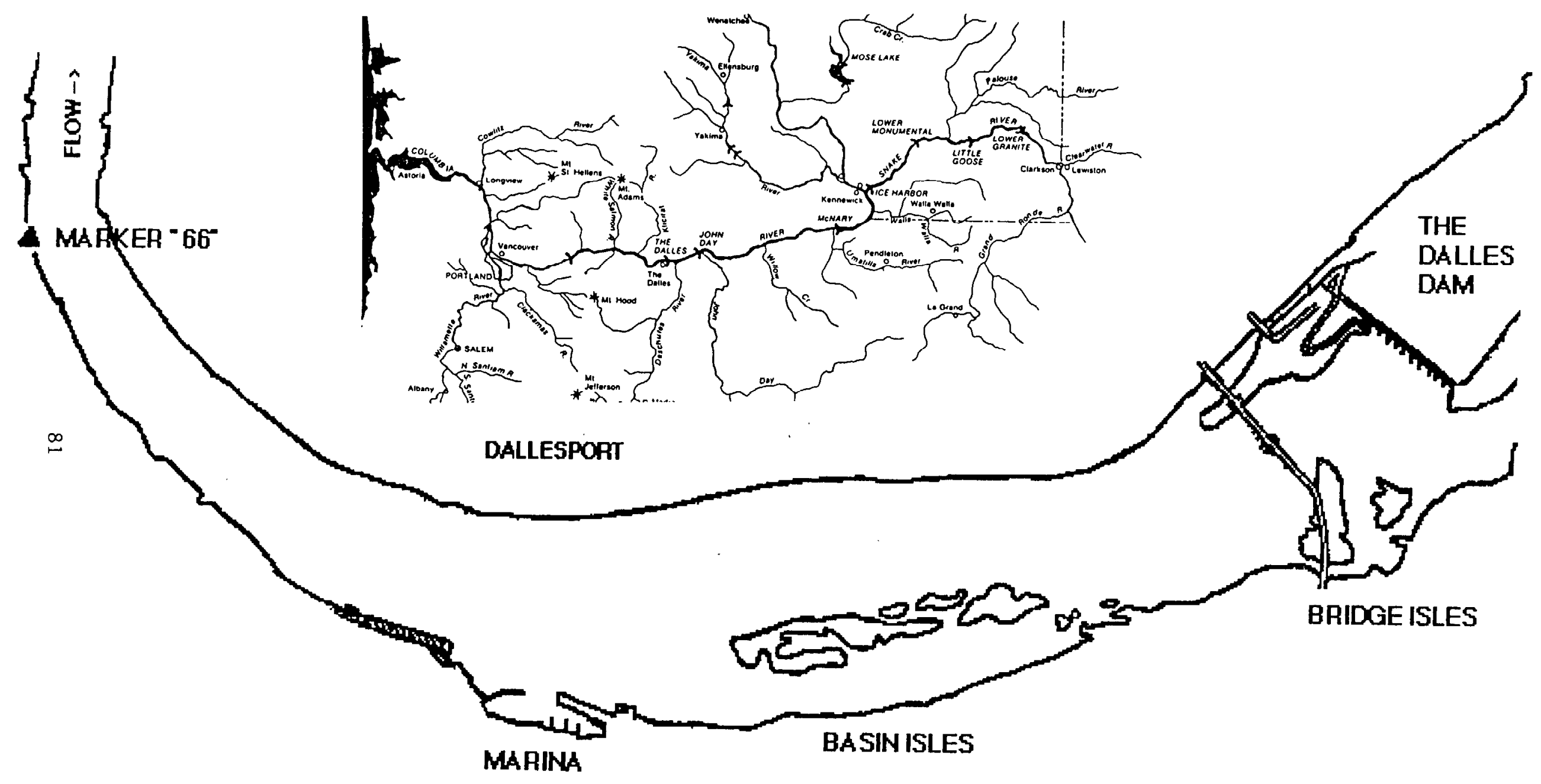

SCALE: 2 CM $=0.25$ MLES

CITY OF THE DALLES 
FIGURE 2: The Dalles Dam tailrace showing release sites. Location and orientation of datalogging antennae indicated by numbers and arrows, respectively.

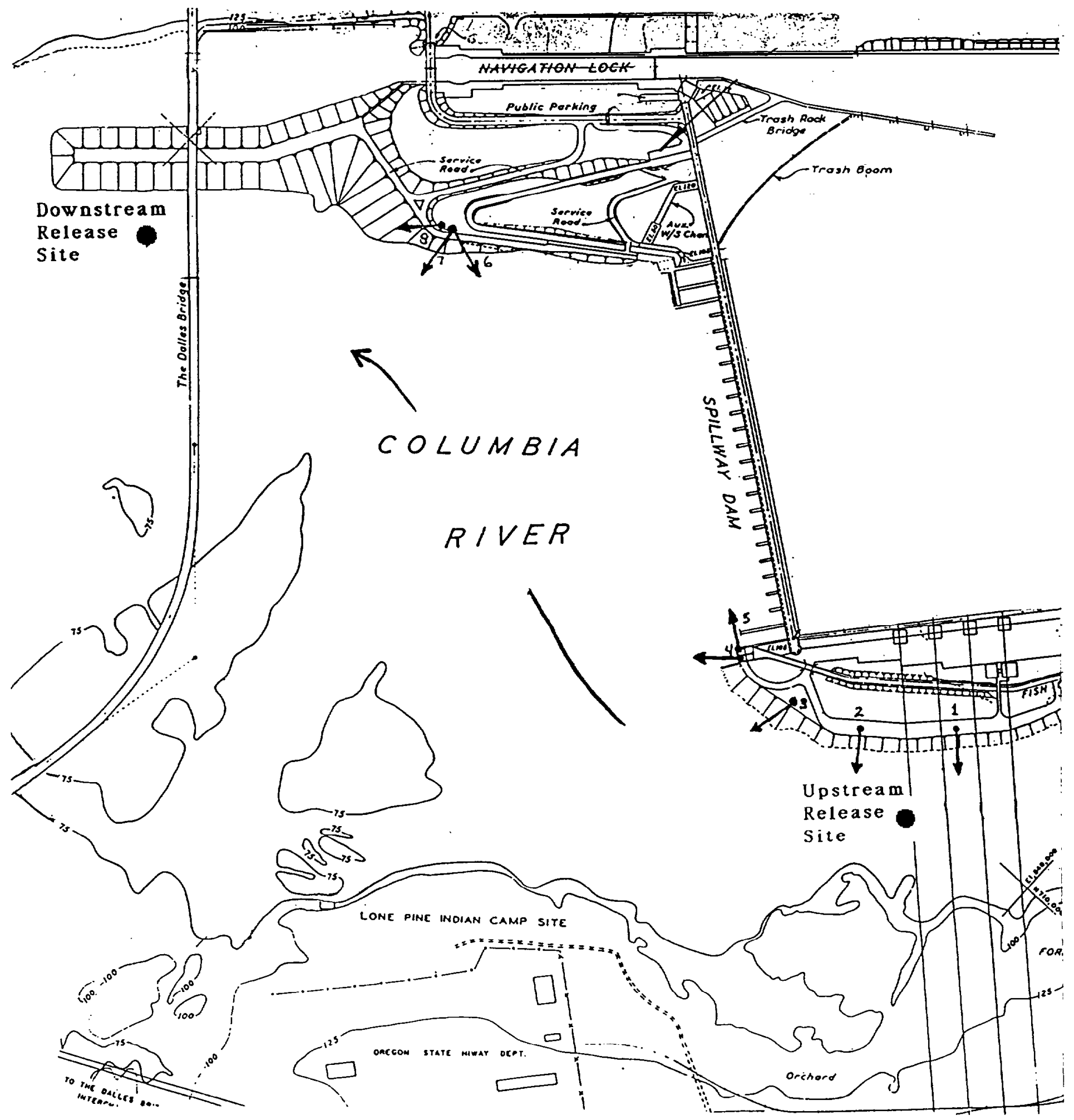

SCALE: $1 \mathrm{CM}=200 \mathrm{FT}$ 
bucket. Once the fish recovered they were moved to live wells suspended in the holds of U.S. Army Corps of Engineer fish barges and transported downriver. Upon reaching The Dalles Dam the fish were quickly transfered to 1 meter, circular holding tanks supplied with free-flowing pumped river water and held for 2-4 days before release.

Each release consisted of a control and treatment group of fish and took place between 0800 and 1000 . Control and treatment fish were moved from holding tanks to the release site as gently as possible in 110 liter containers. Just before release, treatment fish underwent two 5 minute agitations with a 0.5 $\mathrm{hr}$ rest in between agitations to simulate a stress similar to passage through a bypass system. Our agitation-stress treatment was the same as used by Petersen et. al. (1990) except a flexible, plastic sleeving was attached to both buckets to prevent smolts from jumping or falling from the system during pouring.

A total of 60 fish were released and tracked, 31 underwent agitation treatments and 29 were control. On 19 April, 10 Chinook salmon smolts were released from the shoreline near the downstream outfall site. On 23 April, 9 Chinook salmon smolts were released from the shoreline near the upstream outfall site. On 9 May, 11 Steelhead trout smolts were released from a boat approximately 100 meters downstream of the sluiceway and near midchannel. On 15 May, 9 Steelhead trout smolts were released from a boat approximately 50 meters downstream of The Dalles bridge and 30 meters south of the navlock peninsula. On 21 May, 11 Steelhead trout smolts were released at the same location as on 9 May. On 27 May, 10 Steelhead trout smolts were released from the same location as on 15 May.

The change of species occurred when it became impossible to obtain an adequate number of Chinook smolts large enough to allow implantation of the radio transmitters without potential adverse effects on the behavior of the fish. The change from shoreline to boat releases occurred to more exactly simulate the site and river conditions at the proposed potential bypass outfalls.

Radiotracking occurred during the 12 hours immediately after the smolts were released. The location estimates for each fish were roughly circular in 
shape with a diameter varying from 20 to 150 meters. The precision of these locations depended on the tracking technique.

Within the restricted boating zone in the tailrace above the Dalles bridge, an array of antennae interfaced with Lotek (model) datalogging receivers monitored frequencies of tagged fish in their reception zones. Reception zones were mapped out prior to any releases of fish. Between fish variation in the exact size and shape of the reception zone occurred based on differential strength of the transmitted radio signal, the depth of the fish equipped with the transmitter, and the amount of interference present at any paticular time. Whenever possible, an observer monitored the reception of the dataloggers to validate that they were recording properly. By interpreting the strength of reception at each antennae a general location area with a diameter of 100-I 50 meters could be determined.

Radio-tagged fish were also followed by boat using a Lotek receiver and a 4-element yagi mounted on a swivel mast mounted in a 20 -foot Boston Whaler. Reasonably precise location estimates of radio-tagged fish (an area approximately 20-30 meters in diameter) were obtained by adjusting the receiver to a very low reception gain and then passing nearly over the fish. When a large number of rapidly moving fish passed by the tracking boat less precise localizations were made. The size of these location estimates were usually kept to an area of 100 meters or less in diameter.

Tracking was also done from shoreline using a handheld 4-element yagi antenna and a Lotek receiver. These location estimates could usually be no more precise than an area of 150 meters in diameter. However, when radiotagged smolts passed close to shore, trackers obtained several different bearing with quite low reception gains and were thus able to more precisely locate the fish.

One of the major problems that outmigrating smolts face is that many of the slack water areas they would rest and reorient themselves in are also areas where predatory fish are abundant. How quickly smolts that are disoriented and stressed by passage through a dam reach these "holding areas" and in what numbers may greatly influence the number of smolts lost to predation. 
For this study, "holding" by a fish was defined as that fish remaining within a 400 meter or less diameter area for a minimal of 30 minutes. Nettles and Gloss, 1987 used a similar criteria with radiotagged Atlantic salmon to decide when a fish was holding or if it had moved. In their study, fish had to have a location estimate change of at least $0.5 \mathrm{~km}$ before they considered that the fish had moved.

A tracker was situated'on the Oregon shoreline next to river marker " 66 " (See Figure 1) with an antenna directed straight across a narrow section of the river 3 miles downstream of The Dalles bridge. Signal strengths were recorded every 2 minutes for each radio-tagged fish as they passed by. The time at which the maximum signal strength was first obtained would occur when the fish passed through the antenna reception line across the river and was considered the time the fish exited the study area. Passage times were determined by the difference in time between when the fish were released and when they exited the study area. Passage times for the upstream released fish were adjusted for the additional $0.5 \mathrm{mi}$ they traveled when compared to the downstream released fish to allow comparisons between all releases.

All sites where fish were located were denoted on a map and used to determine movement patterns and distribution, holding areas and times, and dispersal rates. Comparisons were then made between different river conditions and release dates, fish sizes, release sites, species, and treatments.

We plotted dispersal patterns on a map of the study area with grids consisting of rectangles $400 \times 600 \mathrm{~m}$. The number of location estimates obtained for all fish was tabulated for each grid in order to better discern holding areas (Figure 3). In order to maximize graphic representation of distribution differences between each cell on the grid, location estimates were grouped by seven.

Outmigration route maps for each release group were made by connecting the centers of each fish's location estimates for that run (Appendix B). Distances traveled at 15, 30, 45, and 60 minutes were determined by measuring the distance between the location estimate for a fish at that time and 
the release site for that fish. If we were unable to locate a smolt at those exact times, an estimate was made by interpolating between the locations obtained at the closest times on either side of the target time. We assumed a constant rate of travel between these two adjacent locations.

River conditions (river flow, turbine output, and river temperatures) were obtained from hourly checks made by Corps of Engineer control room personnel and averaged for the first 8 hours after release (Table 1).

\begin{tabular}{l|l|l|l|l}
\hline $\begin{array}{c}\text { RELEASE } \\
\text { \& } \\
\text { DATE }\end{array}$ & $\begin{array}{c}\text { SPECIES } \\
\text { TAGGED }\end{array}$ & $\begin{array}{c}\text { AVE } \\
\text { TEMP } \\
{ }^{\circ} \mathrm{C}\end{array}$ & $\begin{array}{c}\text { AVE RIVER } \\
\text { FLOW } \\
\text { KCFS }\end{array}$ & $\begin{array}{c}\text { AVE } \\
\text { TURBINE } \\
\text { FLOW } \\
\text { KCFS }\end{array}$ \\
\hline 1 APR. 19 & CHINOOK & 11.3 & 157 & 151 \\
\hline 2 APR. 23 & CHINOOK & 12.0 & 180 & 175 \\
\hline 3 MAY 9 & STEELHEAD & 13.8 & 226 & 219 \\
\hline 4 MAY 15 & STEELHEAD & 13.9 & 222 & 217 \\
\hline 5 MAY 21 & STEELHEAD & 14.7 & 224 & 218 \\
\hline 6 MAY 27 & STEELHEAD & 16.3 & 227 & 221 \\
\hline
\end{tabular}

Table 1: River Conditions During Smolt Releases. Values were averaged over the first $8 \mathrm{hrs}$ after release. 
FIGURE 3: Distribution of all steelhead smolt locations for all releases.

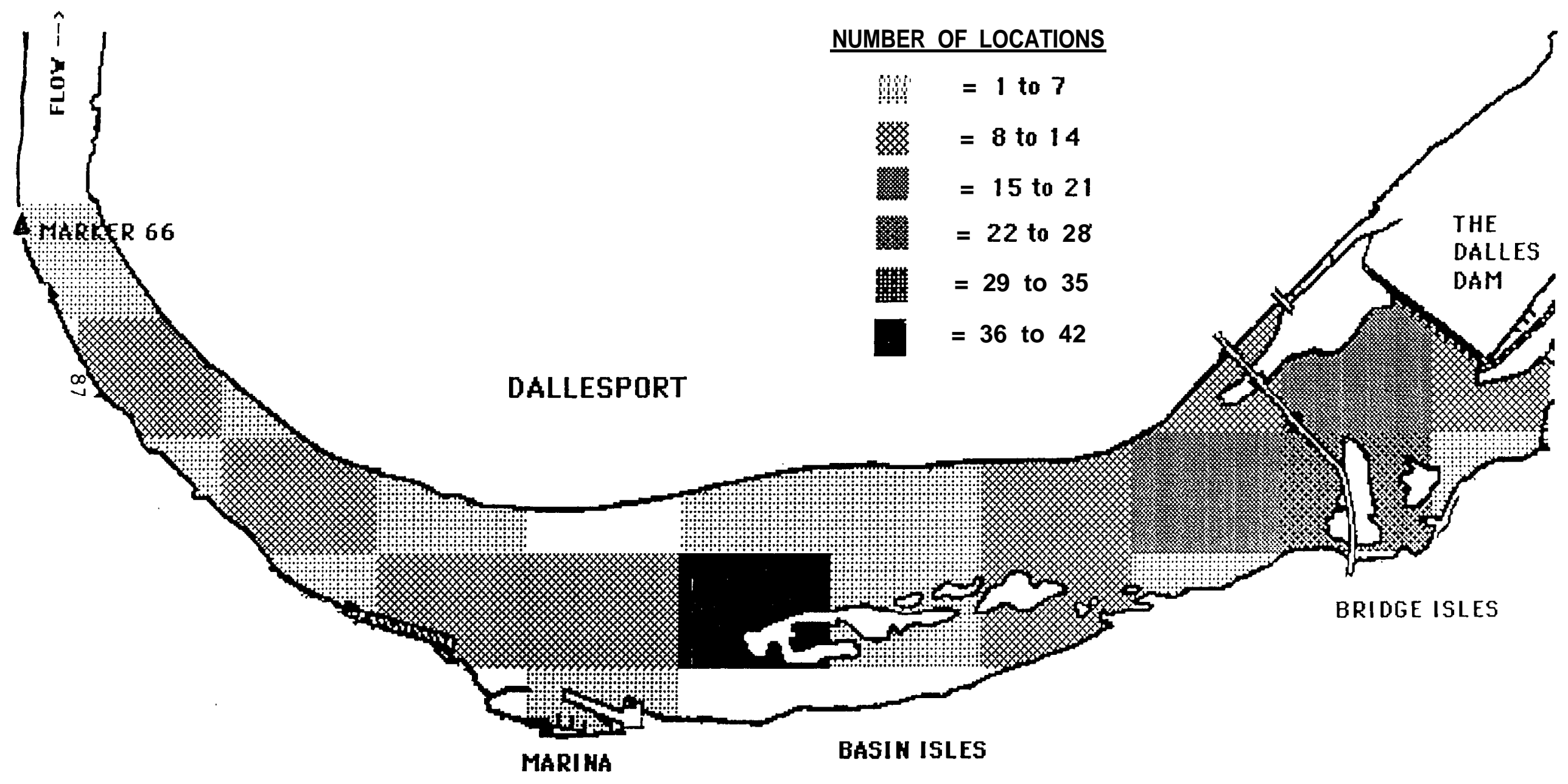

SCALE: $2 \mathrm{CM}=0.25 \mathrm{MI}$

CITY OF THE DALLES 


\section{RESULTS \& DISCUSSION}

A total of 397 location estimates for 54 fish were obtained; 61 for the first release of 10 chinook and 336 for the four releases of 40 steelhead. The location estimates obtained during the second release of 13 chinook were excluded from this total because of difficulties with the datalogging system. The number of location estimates found per fish varied from two to fifteen, depending on how rapidly the fish moved through the study area.

No significant relationship was found between fish size (length and weight) and passage time, distance traveled at $15 \mathrm{~min}$, distance traveled at 30 min, or holding likelihood. This may relate to the relatively large size of the smolts we used this year. Using smaller radiotransmitters and thus a wider range of fish sizes in the future may elucidate differences related to size.

All 10 of the downstream released Chinook held near the release area. Five held at other sites further downstream. Seven of the 10 passed the exit area during the $12 \mathrm{hr}$ tracking period with a mean time of $275 \mathrm{~min}$ (S.D.= 138.4, median $=247$, range, 134-548). The passage times for these fish were significantly slower than for steelhead ( $p=0.017$, unpaired T-test). Chinook outmigration routes for this release of fish (Appendix B) indicate a wider dispersal across the river immediately after release when compared to the steelhead smolts. However, this release did occur much earlier in the season and from close to shore as opposed to later mid-channel release for the steel head.

The data for the upstream release of Chinook is difficult to interpret because of the problems encountered with the initial setup of the datalogging system. Still, 6 of the 9 Chinook released held for a considerable time (109.7 minutes, S.D. $=-16.9$ ) above The Dalles bridge.

There was no significant differences in passage times, dispersal rates, or the number of fish holding between the four groups of steelhead trout we released. This was not surprising when the river condition data for these runs were examined (Table 1). River flow and turbine output varied little, 
temperatures were well within tolerable limits, and all releases occurred during the height of the spring outmigration. This similarity allowed data for all four of the steelhead releases to be combined for analysis comparing release sites, treatments, and potential differences with chinook salmon.

The frequency distribution of steelhead smolt passage times showed a definite skewness to the right. A test for a difference from normality was not significant $(P=0.063)$. Considering the low value of $P$ and an $n=32$, both means and medians were reported. Median passage time for all steelhead smolts was $115 \mathrm{~min}$ with a range from $65-757 \mathrm{~min}$ (mean $=147.3$, S.D. $=119.5$ ). This suggest that fish traveled at $0.25-3.00 \mathrm{mph}$ with a median of $1.65 \mathrm{mph}$ within the first three miles after release. Schreck et. al. (1992) tracked chinook salmon and steelhead trout smolts at night below Bonneville Dam during the same weeks that our tracking took place and found rates of travel over their 10 mile long study area to be very similar to our rates of travel during the day (I-2 $\mathrm{mph}$ ).

Fifteen of the 41 steelhead smolts we released held at least once in the study area. Four held at two different sites. Holding times varied from 37-543 min with a mean of 147.7 min (S.D. $=143.7$ ) and a median of 72.0 min. Holding times for each individual fish are listed in Appendix A. Steelhead released from the downstream site were just as likely to hold as those released from the upstream site , 7 of 19 or $36.8 \%$ and 8 of 22 or $36.4 \%$, respectively $(P=0.437$, unpaired $\mathrm{T}$ test). Steelhead smolts given as additional stress were significantly more likely to hold than the non-stressed steelhead smolts, 10 of 22 or $45.4 \%$ and 5 of 19 or $26.3 \%$, respectively $(P=0.024$, unpaired $T$ test).

Two major holding areas were discovered for the steelhead smolts, the Bridge Isles for fish released from the upstream release site and the Basin Isles for fish released from either the upstream or downstream release site (See Figure 1). Of the 15 steelhead smolts that held, 7 held at the Basin Isles and 5 at the Bridge Isles. The map showing the distribution of all the locations where we found steelhead (Figure 3) also indicated these two island groups as heavy use areas. 
There was a significant difference between upstream and downstream released steelhead smolts in the amount of time it took for those fish that held to reach their first holding site $(P=0.003$, unpaired $T$-test). Steelhead trout released upstream took an average of $11 . I \mathrm{~min}$ (S.D. = 8.2) to reach their first holding site while steelhead trout released downstream took an average of $39.0 \mathrm{~min}$ (SD. = 16.9). Two upstream and one downstream released fish that did hold were not included in this analysis because we were unable to locate them for an extended period of time before they were first found holding. Most likely, they had either held elsewhere or we missed them during earlier tracking efforts.

Upstream released steelhead smolts also dispersed significantly slower ( $P=0.001$ at $15 \mathrm{~min}, P=0.011$ at $30 \mathrm{~min}$, unpaired T-tests) than did fish released at the downstream site in the first 30 minutes after release (Figure 4). Stressed and non-stressed groups did not differ $(P=0.680$ at $15 \mathrm{~min}, P=0.959$ at $30 \mathrm{~min}$, unpaired T-tests) in their dispersal rates (Figure 5). Overall, the fish tended to spread out more and more as time following release progressed.

The outmigration routes used by the steelhead smolts tended to follow along the south side of the main channel for the first two miles below the dam and then to spread out more across the river (Appendix.B).

Nine of 41 steelhead trout smolts remained within the study area during the $12 \mathrm{hr}$ tracking period following their release, having never passed the exit area. Seven of the nine fish were fish released at the upstream site. Tracking patterns of five of these nine smolts strongly suggested to us that these five fish were preyed upon. Three of the signals from their transmitters remained fixed in small areas of the river for 6-9 hrs until the $12 \mathrm{hr}$ tracking period ended, one in a high current area and one after rapidly moving upstream against a strong currents. In subsequent days none of the three signals transmitters were heard again. The signals from the other two dissapeared near the Bridge Isles where the water is deep and there are many areas for predators to lay in wait. These two signals were heard again briefly later in the day in the same vicinity, then never heard again. Both release location and stress may have increased the vulnerablity of these smolts to predation as 4 of these 5 fish were fish released 
FIGURE 4: Distance traveled in miles (mean and standard error) for upstream and downstream released steelhead trout smolts Signlficant dlfference between upstream and downstream fish at 15 and 30 $\min (P<0.05)$.

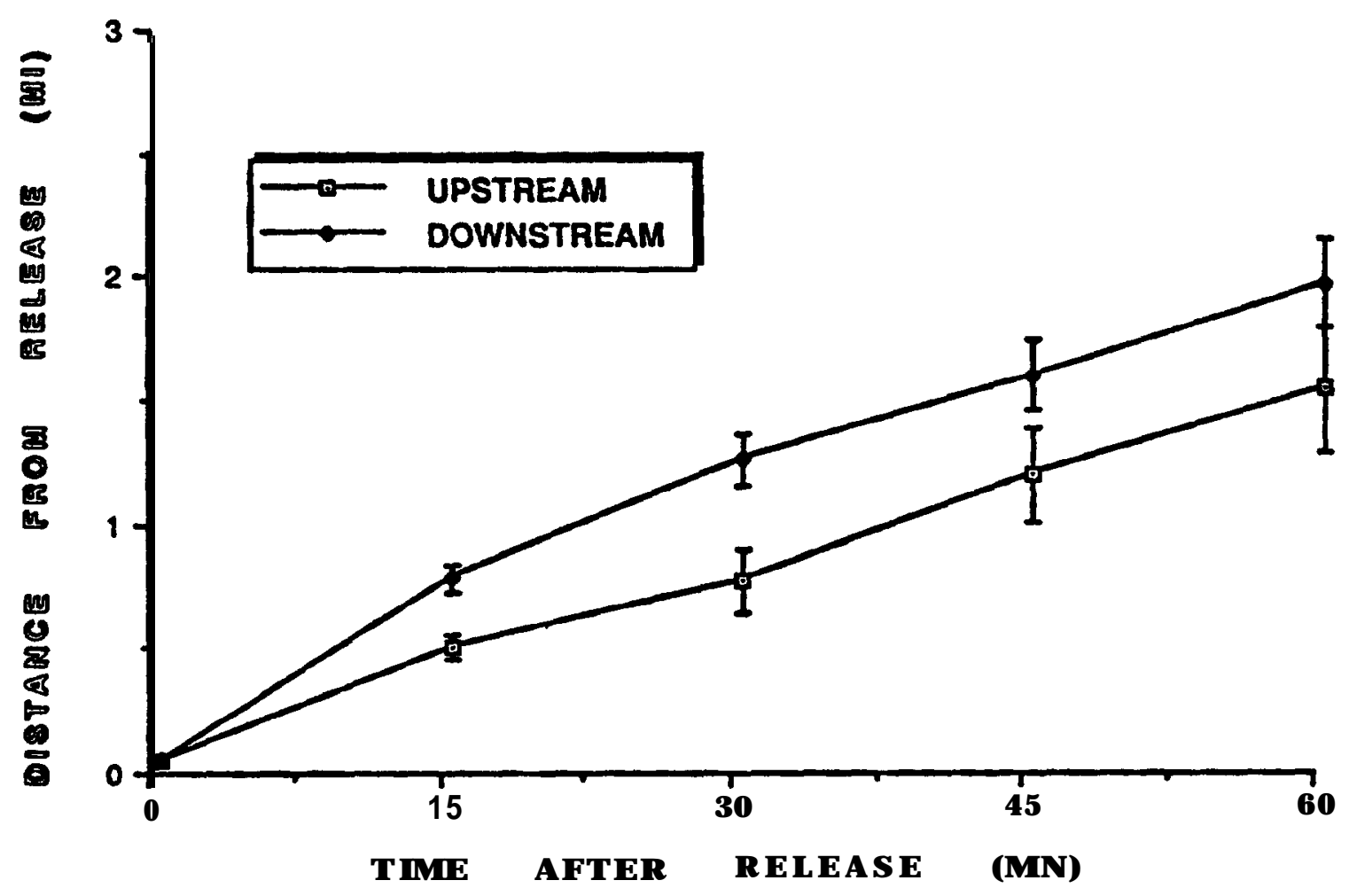


FIGURE 5: Distance traveled in miles (mean and standard error) for control and stressed steelhead trout smolts. No significant differences.

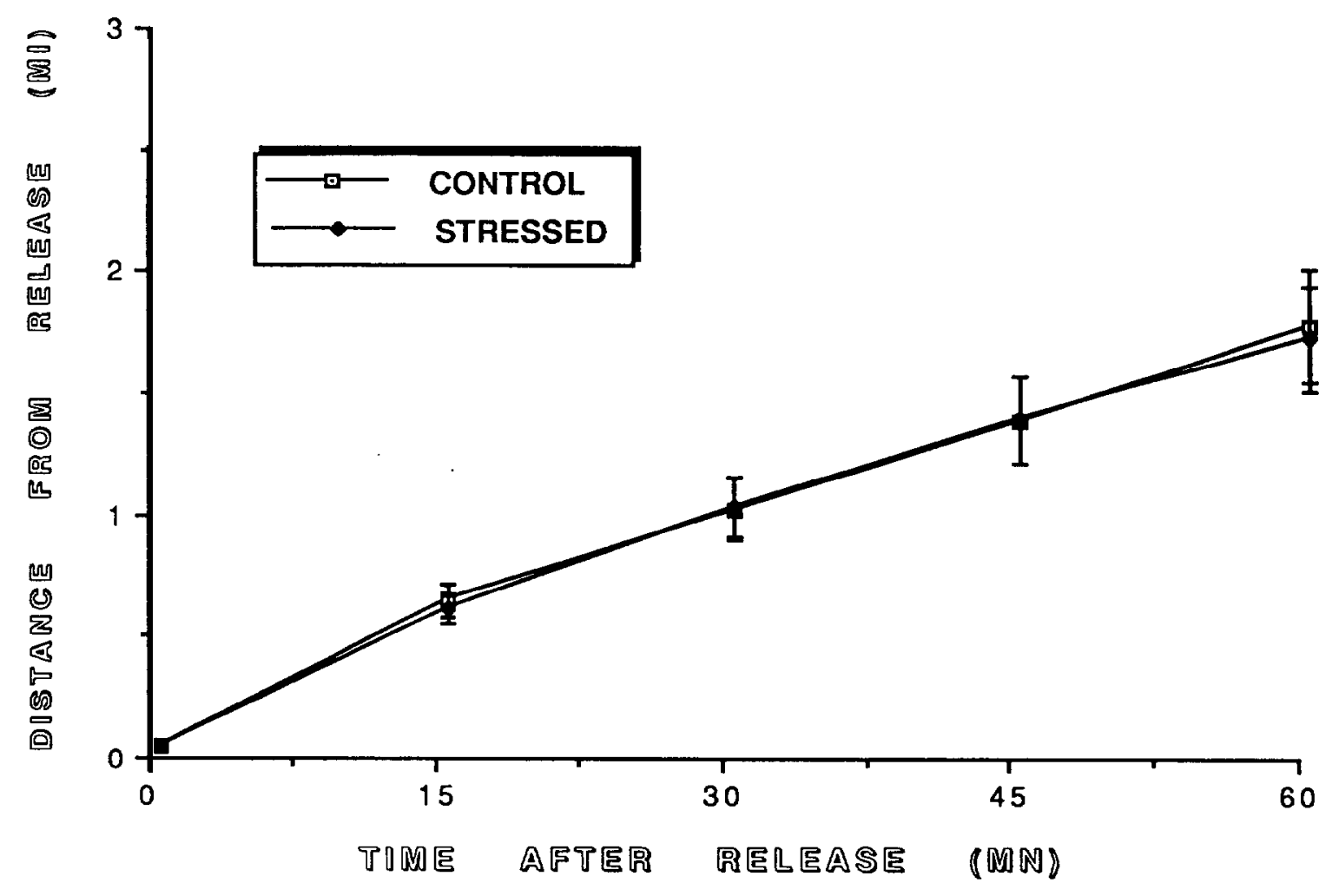


from the upstream site and 4 of the 5 had received a secondary stress challenge prior to release.

Our data shows that over a third of ail the steelhead trout we released and nearly half of those that were stressed searched out a place to hold following release. if this behavior is typical, this suggests that a large number of juvenile salmonids passing through hydroelectric plants need time to rest and reorient themselves. if the river flow in the vicinity of an outfall quickly moves large numbers of these smoits into potential holding areas before they have time to recover, they may be more susceptible to predation because those same holding areas may also be locations with dense predatory fish populations.

The location of bypass outfails, or any other location where fish pass out of dams, and the influence of dam operations on river flows may be critical to the effects of predation on outmigrating salmonids. in our study, steelhead smolts released at the upstream site had half as far to travel and less than onethird the time before reaching their first holding area. The surface currents in that area rapidly moved into a series of turns, that potentially could move many of the smoits into an area of rocks and abundant pockets of relatively still water, especially if they are searching for a place to hold. This may have been the case in our study as 4 of the 5 fish we suspect were preyed upon were released from the upstream release site. Stress may compound this problem, since a greater percentage of stressed fish rather than unstressed fish tended to hold. Similar holding tendencies and predation problems may exist in any area below a major stressor, such as waterfalls and irrigation diversions.

1993 work at The Dailes Dam will focus on obtaining detailed information on spring chinook to better describe their outmigratory and dispersal behavior. For this to happen a smaller transmitter with adequate power to be able to track across fairly long distances is needed.

Since the end of the field season we have obtained and tested prototype transmitters from Advanced Telemetry Systems, Inc., Isanti, Mn that are approximately one third the volume and less than one half the in-air weight (15 $x 7 \mathrm{~mm}, 1.4 \mathrm{~g}$ ) of those we used this field season. Their performance in range testing, both in air and in water, was nearly the same as the transmitters we 
used this field season and therefore, they can be substituted with little or no effect on our ability to track fish.

Presently, we are testing dummy transmitters, made to simulate as closely as possible these smaller transmitters, to determine if chinook salmon juveniles with forklengths of $10-15 \mathrm{~cm}$. can tolerate such radio devices. These tests are ongoing and preliminary results from the first replicate suggest that, although there may be some effect on feeding ability, chinook juveniles down to around $12 \mathrm{~cm}$ forklength can be safely implanted with these transmitters.

Swimming performance testing of chinook salmon of these sizes with implanted transmitters will begin subsequently. 


\section{REFERENCES}

Giorgi, A.E. and L.C. Stuehrenberg. 1983. Smolt passage behavior and flow-net relationships in the forebay of John Day Dam, 1984, Annual Report, (Contract DE-Al 79-83BP39644) Bonneville Power Administration, Portland, OR.]

Giorgi, A.E., L.C. Stuehrenberg, D.R. Miller, C.W. Sims. 1985. Smolt passage behavior and flow-net relationships in the forebay of John Day Dam, 1985, Annual Report, (Contract DE-Al 79-83BP39644) Bonneville Power Administration, Portland, OR.]

Giorgi, A.E., L. Steuhrenberg, and J. Wilson. 1988. Juvenile radio-tag study: Lower Granite dam, 1985-86, Final Report, (Contract DE-Al 7985BP21237) Bonneville Power Administration, Portland, OR.

Ledgerwood, R.O., E.M. Dawley, L.G. Gilbreath, P.J. Bentley, B.P. Sanford, and M. H. Schiewe. 1991. Relative survival of subyearling chinook salmon that have passed through the turbines or bypass system of Bonneville Dam Second Powerhouse, 1990. Report to U.S. Army Corps of Engineers, Contract E86900104.

Mesa, M.G. 1992. Effects of multiple acute disturbances on the predator avoidance, physiology, and behavior of juvenile chinook salmon. Report 4. in Poe, T.P. (ed.), Significance of selective predation and development of prey protection measures for juvenile salmonids in Columbia and Snake River reservoirs, 1991, Annual Report, (Contract DEAI79-88BP91964) Bonneville Power Administration, Portland, OR.

Petersen, J. H., M. G. Mesa, J. Hail-Griswold, W. C. Schrader, G. W. Short, and T. P. Poe. 1990. Magnitude and dynamics of predation on juvenile salmonids in Columbia and Snake river reservoirs. Annual Report. (Contract DE-Al79-88BP91964) Bonneville Power Authority, Portland, OR.

Poe, T.P., H. C. Hansel, S. Viggs, O. E. Palmer, and L.A. Prendergast. 1991. Feeding of predaceous fishes on out-migrating juvenile salmonids in John Day reservoir, Columbia River. Trans. Am. Fish. Soc. 120: 405420. 
Schreck, C. B., S. Kattari, J.L. Congieton, and L. E. Davis. 1992. Evaluation of facilities for collection, bypass, and transportation of outmigrating chinook salmon. Draft Annual Report to U.S. Army Corps of Engineers, Waiia Walla District, Research Element JFT-92-Xx-3.

Stier, D.J. and B. Kynard. 1986. Use of radio telemetry to determine the mortality of Atlantic salmon smoits passed through a 17-MW Kaplan turbine at a low-head hydroelectric dam. Tran. Am. Fish. Soc. 115:771775 .

Stuehrenberg, L.C., A.E. Giorgi, C.W. Sims, J Ramonda-Powell, and J. Wilson. 1986. Juvenile radio-tag study: Lower Granite dam, 1985, Annual Report, (Contract DE-Al 79-85BP21237) Bonneville Power Administration, Portland, OR.

Viggs, S., T.P. Poe, L.A. Prendergast, and H.C. Hansel. 1991. Rates of consumption of juvenile salmonids and alternative prey fish by northern squawfish, walleyes, smallmouth bass, and channel catfish in John Day reservoir, Columbia River. Trans. Am. Fish. Soc. 120: 421-438. 


\section{APPENDIX A}

Summary table listing results for each fish by species, radio

frequency, release date, release site, and treatment $(A G=$ agitation stressed group, $\mathrm{C}=$ control group). 
1992 CHINOOK DATA

\begin{tabular}{|c|c|c|c|c|c|c|c|c|c|c|c|c|c|c|}
\hline & FREOUENCY & REL DATE & DS/US SITE & $A G / C P A A S T$ & $(M N)$ & $\max$ & MPH & FISH WEIGHT & FISH LENGTH & HOLO TI ME & HOLD SITE & HOLD TIME & HOL. TIME & RIVERCFS \\
\hline I & 149419 & $4 / 19 / 92$ & DS & AG & 269 & & 170 & 1025 & 211 & 77 & NAVLOCK PEN & FERRY XINĜ & & 1573 \\
\hline 2 & 149469 & $4 / 19 / 92$ & DS & c & 134 & & 2.00 & 673 & 182 & 46 & NAVLOCK PEN & & & 1573 \\
\hline 3 & 149388 & $4 / 19 / 92$ & DS & c & 172 & & 2.23 & 879 & 200 & 65 & NAVLOCK PEN & & & $157 \pi$ \\
\hline 4 & 149178 & $4 / 19 / 92$ & OS & c & 548 & & 1.65 & 619 & 181 & 53 & NAVLOCK PEN & 3040 BASIN ISIES & & 1573 \\
\hline 5 & 149050 & $4 / 19 / 92$ & DS & c & 3-15 & & 1.38 & 768 & 192 & 46 & NAVLOCK PEN & 34 FERRY XING & & 1573 \\
\hline 6 & 149251 & $4 / 19 / 92$ & DS & AG & 210 & & $\begin{array}{l}1 \quad 59 \\
\end{array}$ & 942 & $210 \quad$ EXIT & 46 & NAVLOCK PEN & & & 1573 \\
\hline 7 & 149219 & $4 / 19 / 92$ & DS & AG & & & 083 & 923 & 200 LAST AT PIER & 145 & NAVLOCK PEN & 81 D BASINISLES & 45 MARINA AREA & 1573 \\
\hline 8 & 144439 & $4 / 19 / 92$ & DS & $A G$ & 247 & & 1.87 & 881 & $20.1 \quad$ EXIT & 33 & NAVLOCK PEN & 58 NORTH SHORE & 38 MARINA AREA & 1573 \\
\hline 9 & 143318 & $4119 / 92$ & DS & $A G$ & & & & 800 & 19.5 LAST AT REL & NEVER LEFT & NAVLOCK PEN & & & 1573 \\
\hline 10 & 149428 & $\$ / 19 / 92$ & DS & c & & & & 60.3 & 178 LAST AT REL & NEVER LEFT & NAVLOCK PEN & & & 1573 \\
\hline 11 & 149009 & $4 / 23 / 92$ & us & c & & & & 126.4 & 22 ILAST AT AAS & $5 \quad 80$ & $A A 2-A A 3$ & & & 1802 \\
\hline 12 & 149020 & $4 / 23 / 92$ & us & $\mathrm{c}$ & & & & 719 & is 7 DISSAPEARED & & & & & 1802 \\
\hline 14 & 149150 & $4 / 23 / 92$ & US & AG & & & & 762 & 198 LAST AT AA2 & 117 & AA2 AREA & & & 1202 \\
\hline 15 & 149200 & $4 / 23 / 92$ & us & s. & & & & 1226 & 222 DISSAPEARED & & & & & 1302 \\
\hline 16 & 149281 & $4 / 23 / 92$ & us & $\mathrm{c}$ & & & & 948 & 207 LONG IN AA7 & 150 & BRIDGE ISLES & & & 1802 \\
\hline 17 & 149299 & $4 / 23 / 92$ & us & AG & & & & 1017 & $\begin{array}{l}215 \text { LAST AT AA3 } \\
2.45\end{array}$ & & & & & $180=$ \\
\hline 18 & 149339 & $4 / 23 / 92$ & us & $\mathrm{c}$ & & & & $105 \mathrm{a}$ & 187 LONG IN AA? & 148 & AA7 AREA & & & 1802 \\
\hline 19 & 149399 & $4 / 23 / 92$ & us & SL & & & & 691 & 19.0 SLOW BYAA 7 & $120^{\circ}$ & BRIDGE ISLES & & & 1002 \\
\hline 20 & 149409 & $4 / 23 / 92$ & us & $A G$ & & & & 76.6 & 190 FAST BY AA7 & & & & & 1802 \\
\hline 21 & 140450 & $4 / 23 / 92$ & us & AG & & & & 758 & 195 LONG IN AA7 & $43+$ & BRIDGE ISLES & & & 1802 \\
\hline 22 & 149478 & $4 / 23 / 92$ & us & 54 & & & & 833 & 205 DISSAPEARED & & & & & 1302 \\
\hline 23 & 148859 & $4 / 23 / 92$ & us & $\mathrm{c}$ & & & & 1326 & 230 LONG IN AA7 & 120 & AA7 AREA & & & 1002 \\
\hline 24 & & & & & & & & & & & & & & 1802 \\
\hline
\end{tabular}


1992 STEELHEAD DATA

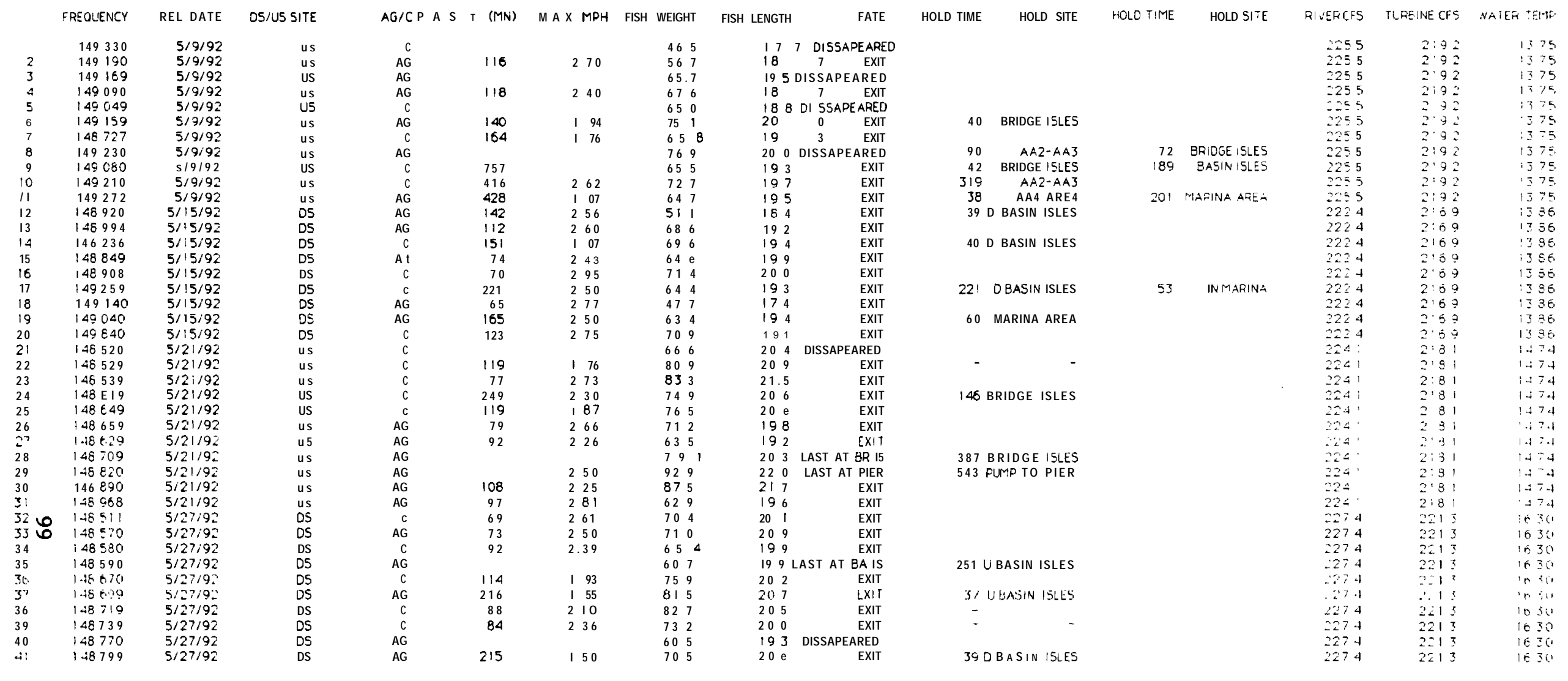




\section{APPENDIX B}

Outmigration route maps of each tracked fish for each release group, made by connecting the center of all location estimate for each smolt 


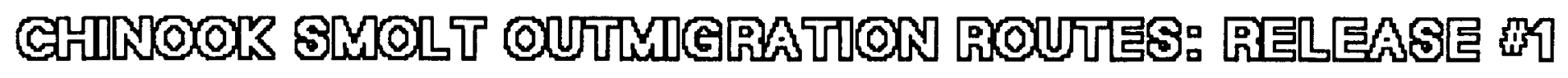

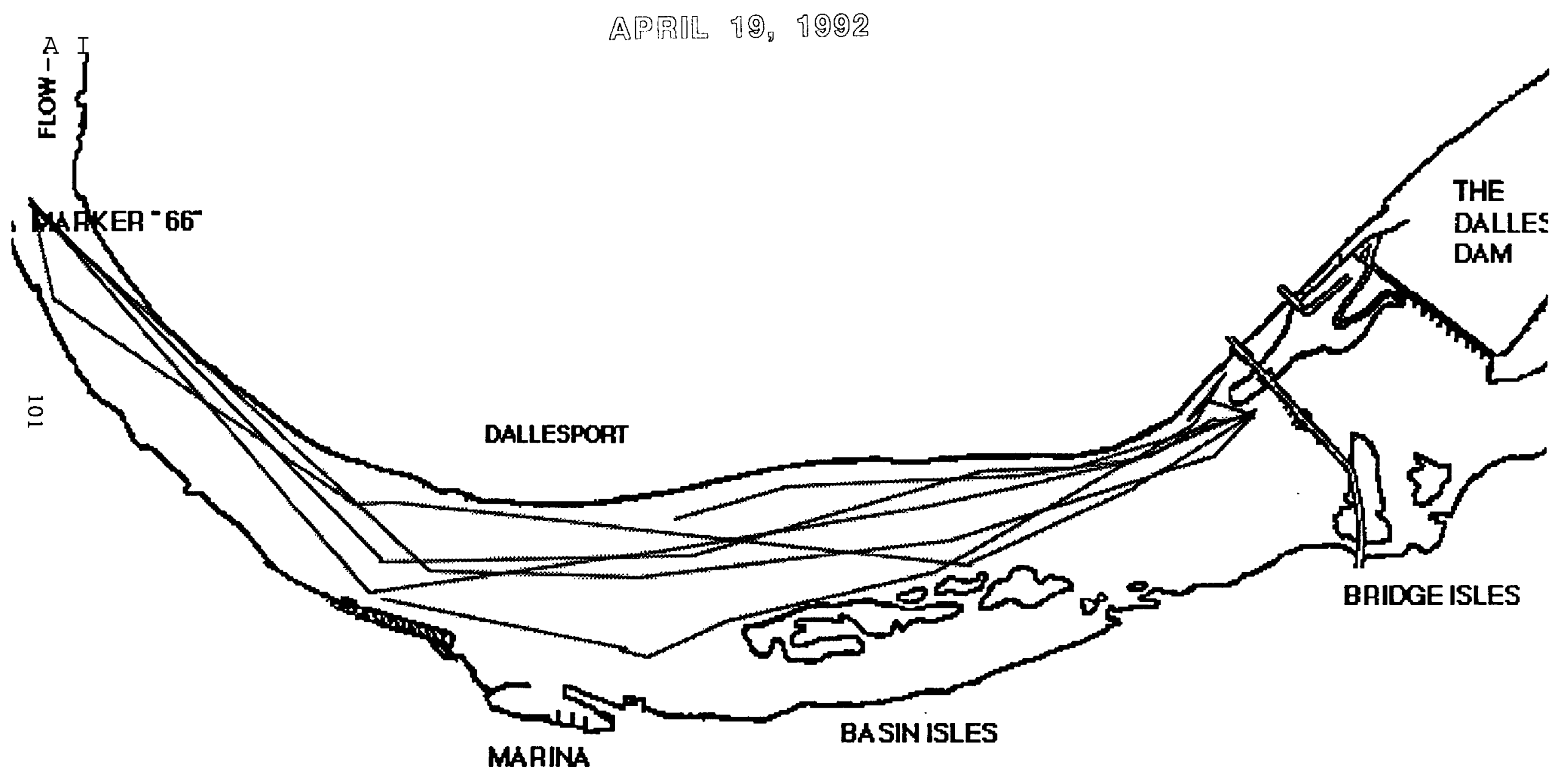

SCALE: 2 CM = 0.25 H LES

CITY OF THE DALLES 


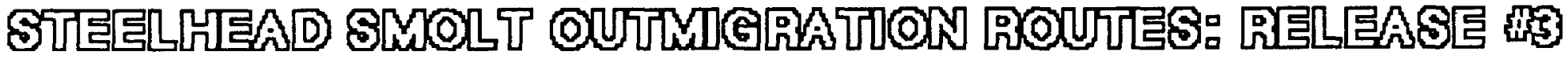

MA因Y 9, 1982

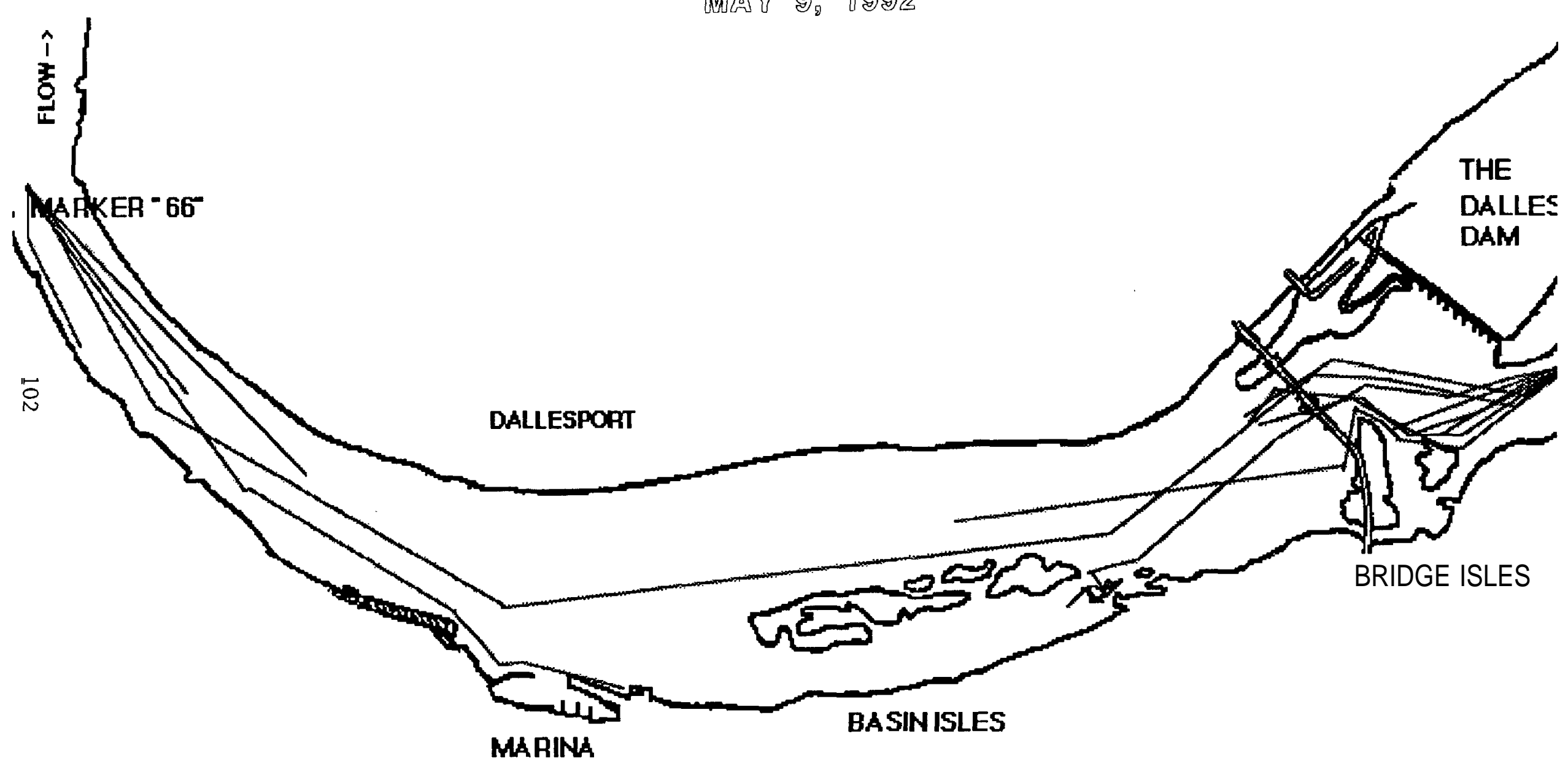

SCALE: 2 CM $=0.25$ MLES 


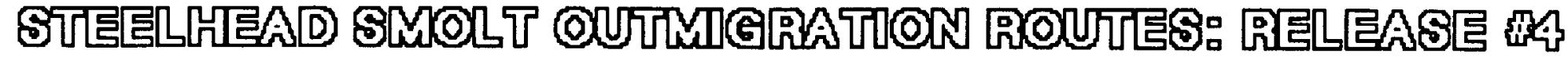

MAY โ5, 7982

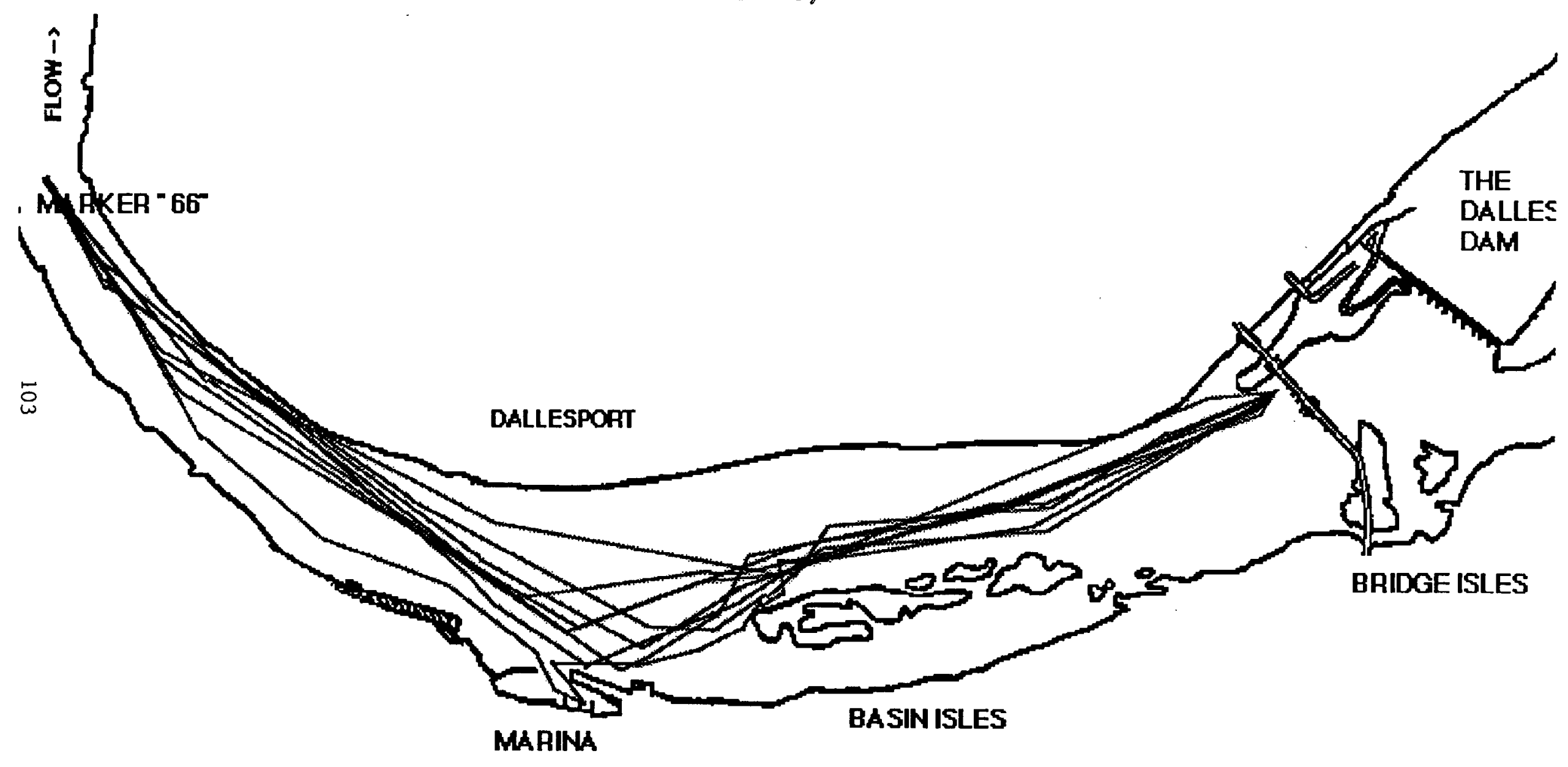

SCALE: 2 CM $=0.25$ MLES

CITY OF THE DALLES 


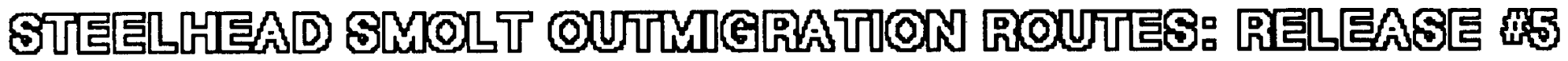

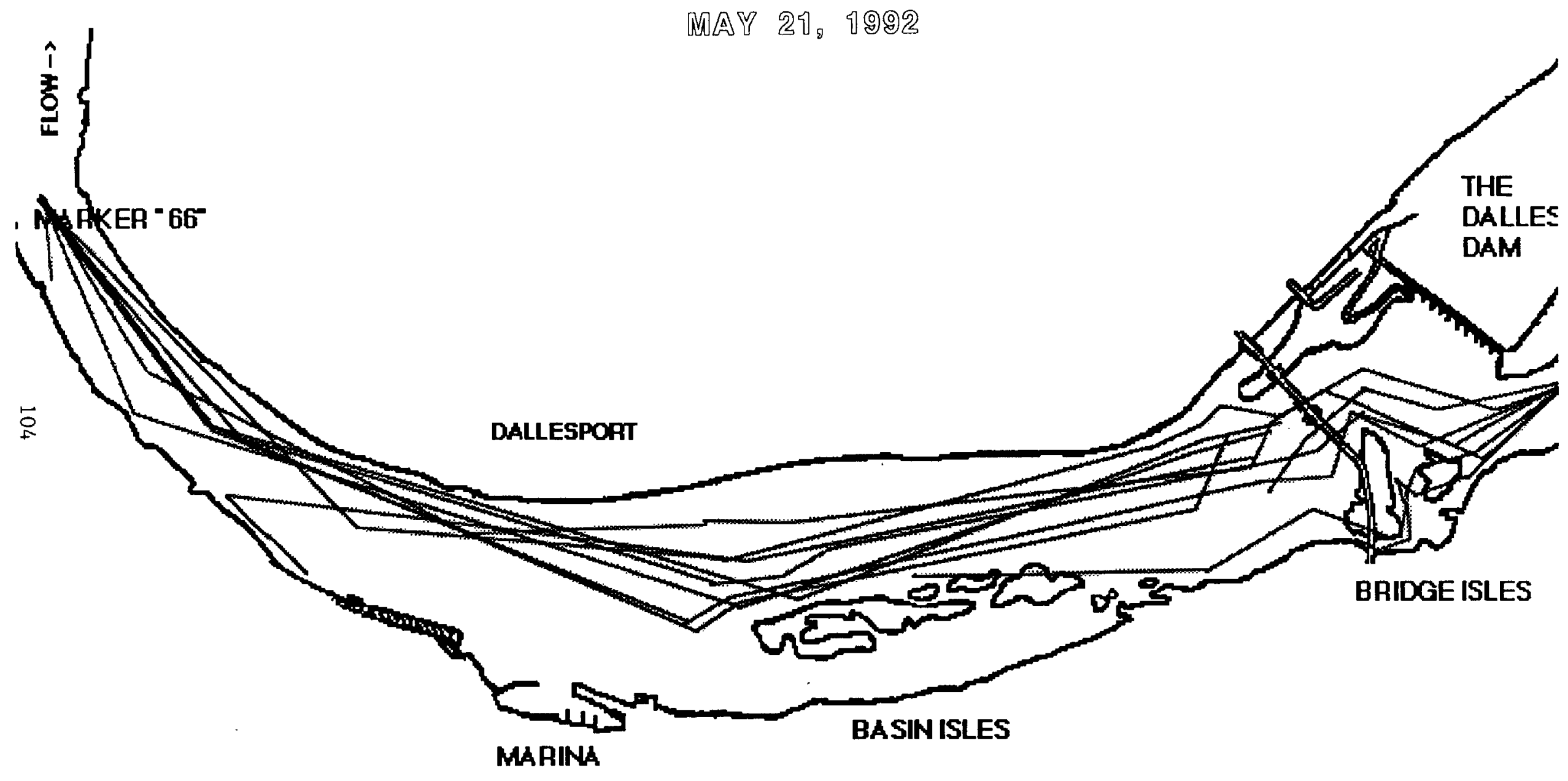

SCALE: 2 CH $=0.25 \mathrm{MLES}$

CITY OF THE DALLES 


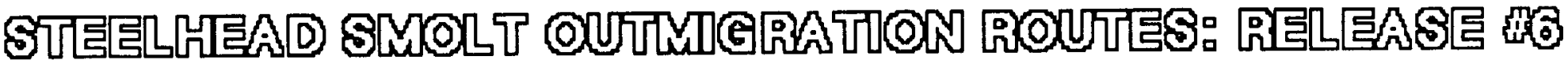

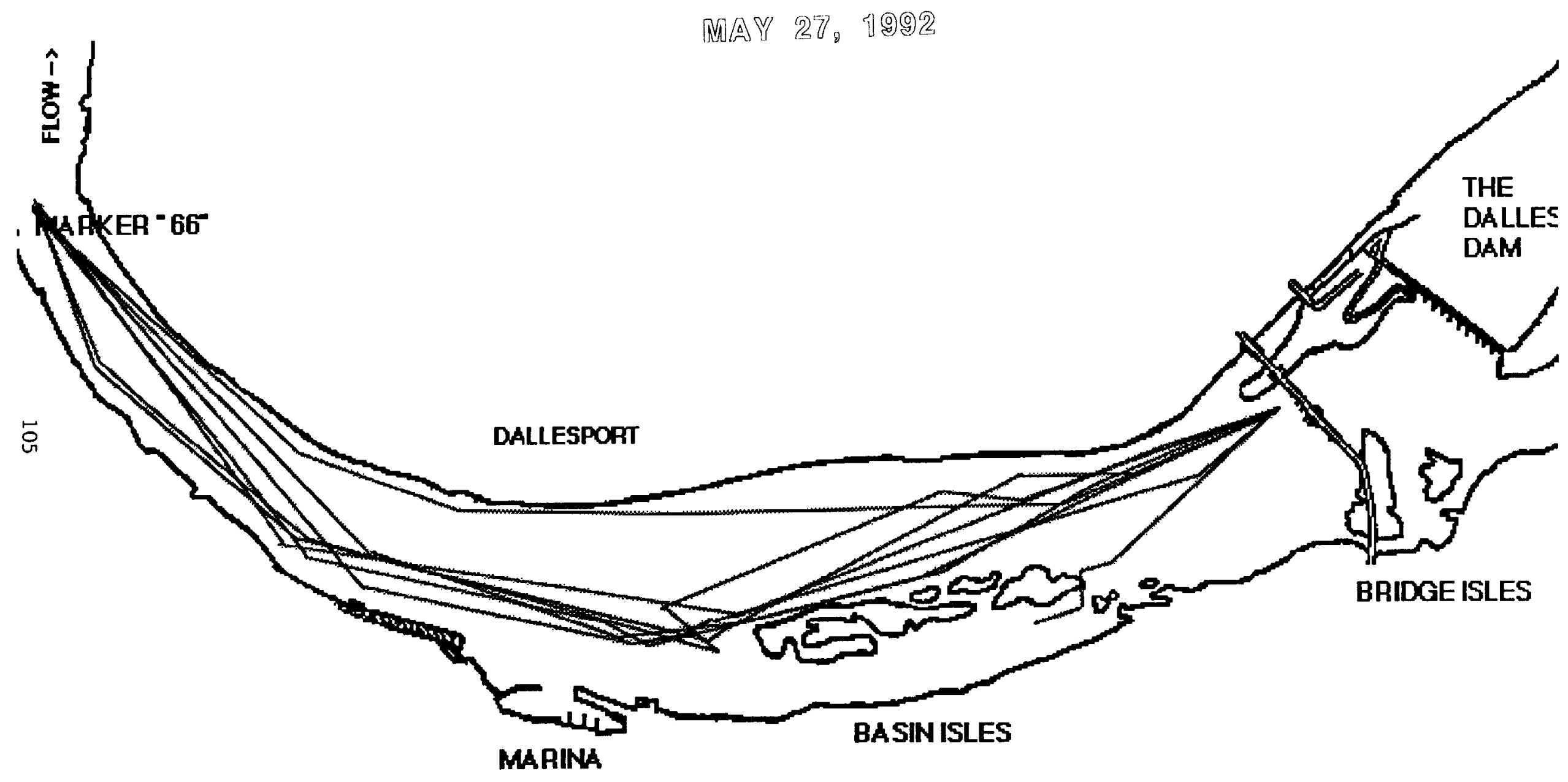

SCALE: 2 CM $=0.25$ MLES

CITY OF THE DALLES 


\section{Report 7}

Movements of Northern Squawfish Near
Lower Granite Dam in the Spring of 1992

D.J. Isaak and T.C. Bjornn

Idaho Cooperative Fish and Wildlife Research Unit University of Idaho, Moscow, ID 83843 


\begin{abstract}
Seventy-seven northern squawfish were implanted with radio transmitters and released downstream from Lower Granite Dam during the initial year of a project to study their movements and distributions near lower snake River dams. Methods were developed to monitor squawfish movements during and after the smolt migration. Transmitter failure rates approaching 86\% hampered the acquisition of data. Squawfish distributions near Lower Granite Dam were found to vary significantly during the day. Squawfish spent the majority of their time in a slackwater area near the north shore fish ladder entrance. Movements into the turbine discharge were observed.
\end{abstract}


Introduction

The general objectives of the study were to develop the equipment and procedures needed to monitor northern squawfish Ptychocheilus oregonensis movements and then to assess their movements at lower Snake River dams, particularly in the tailrace areas and near smolt bypass outfalls. The study proposal encompasses all four lower Snake River dams, however, the initial year (1992) was limited to Little Goose Reservoir (Figure 1). This allowed the development of the necessary monitoring procedures that will be utilized at all Lower Snake River Dams in the future.

Specific objectives for 1992 included: 1) determination of the best method of attaching radio transmitters to squawfish, 2) determination and installation of the receiver, transmitter, and antenna setups that would be necessary to monitor movements of individual squawfish in tailrace and smolt bypass exit areas near dams, and 3) monitoring the range of movements of squawfish during the smolt migration season.

Methods

Objective 1 .

Twenty squawfish were collected from the Snake River in late March and brought to the University of Idaho to serve as test subjects. Several fish were implanted with dummy transmitters using one of two methods. 


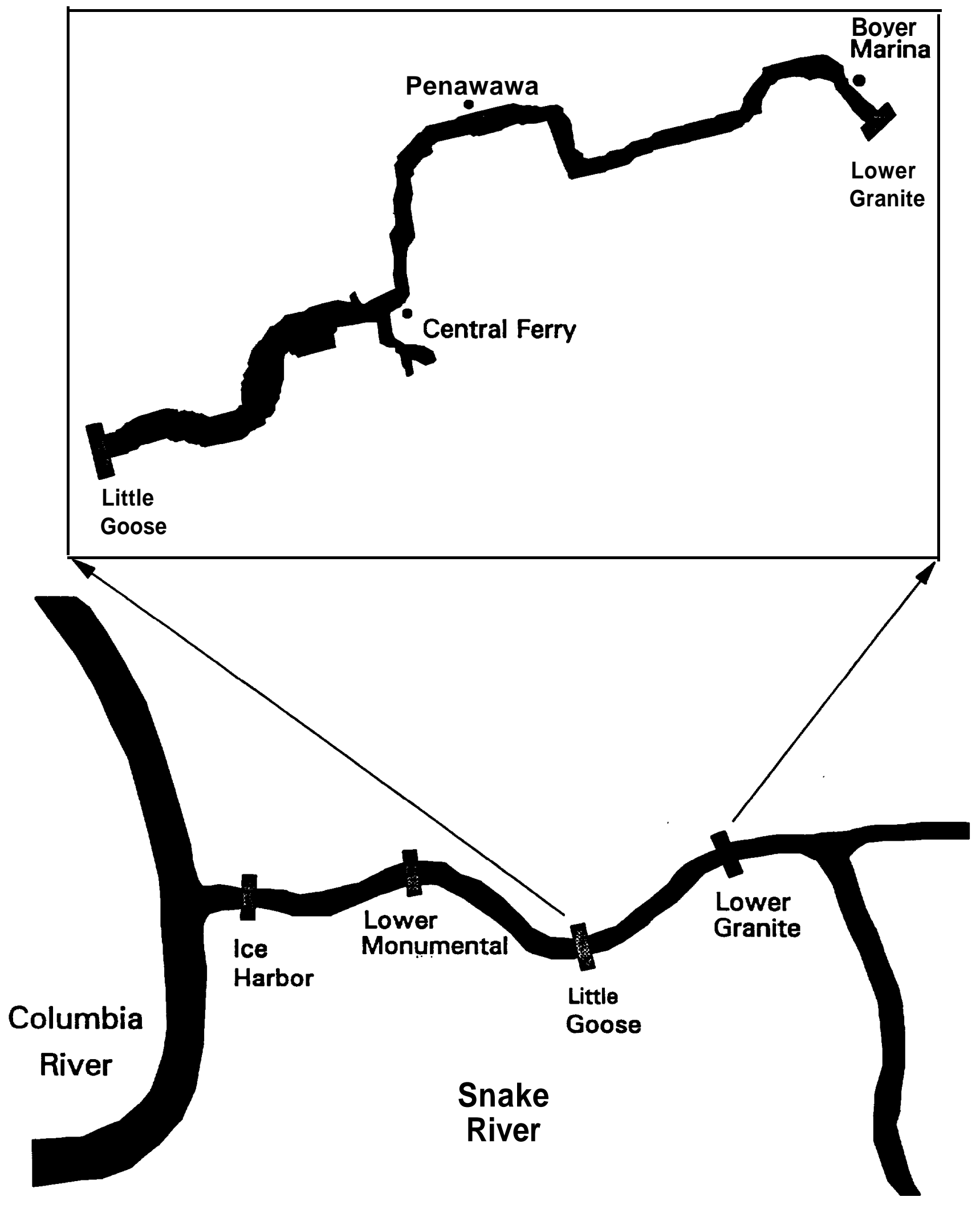

Figure 1. Map of the lower Snake River and the area between Lower Granite and Little Goose dams, first year study site. 
The location of the incision and subsequent transmitter placement were the only significant differences between the two methods. Method 1 placed the incision anterior and slightly ventral to the insertion of the left pelvic fin (Figure 2). Method 2 called for the incision to be placed along the mid-ventral line, immediately anterior to the pelvic girdle. A hypodermic needle was then'pushed through the skin approximately $2.54 \mathrm{~cm}$ posterior to the incision and extended through the larger incision. The whip antenna of the transmitter was threaded through the needle and the needle removed. Finally, the body of the transmitter was coerced into the gut cavity of the fish and the incision sewn up. Additional details of the surgical procedure are covered extensively by Bidgood (1980).

Several fish were implanted with dummy transmitters using both methods. Method 1 was rejected in favor of method 2 for two reasons. When method 1 was employed, a clean closure of the incision was difficult to obtain and second, the morphology of the fish made the operation more awkward. Time constraints prohibited the evaluation of each method's long term effects on survival. Objective 2 .

Fixed receiving stations were established at several locations to monitor areas- of special interest on a continual basis (Figure 3). Lower Granite \#l had been established a year prior in connection with a separate study. This station was located $1.6 \mathrm{~km}$ downstream from 


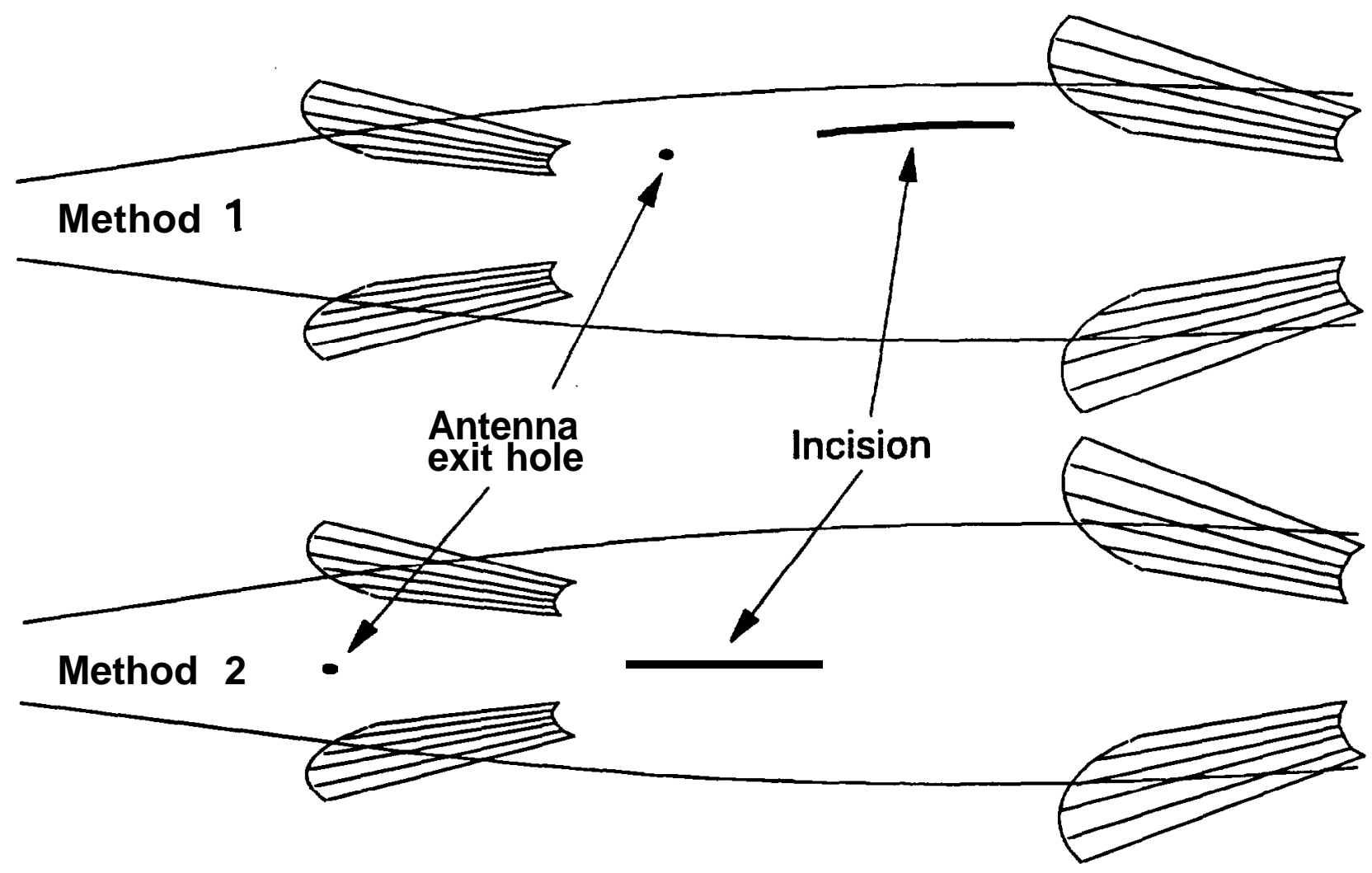

Figure 2. Incision placement for two surgical procedures performed on northern squawfish in 1992.

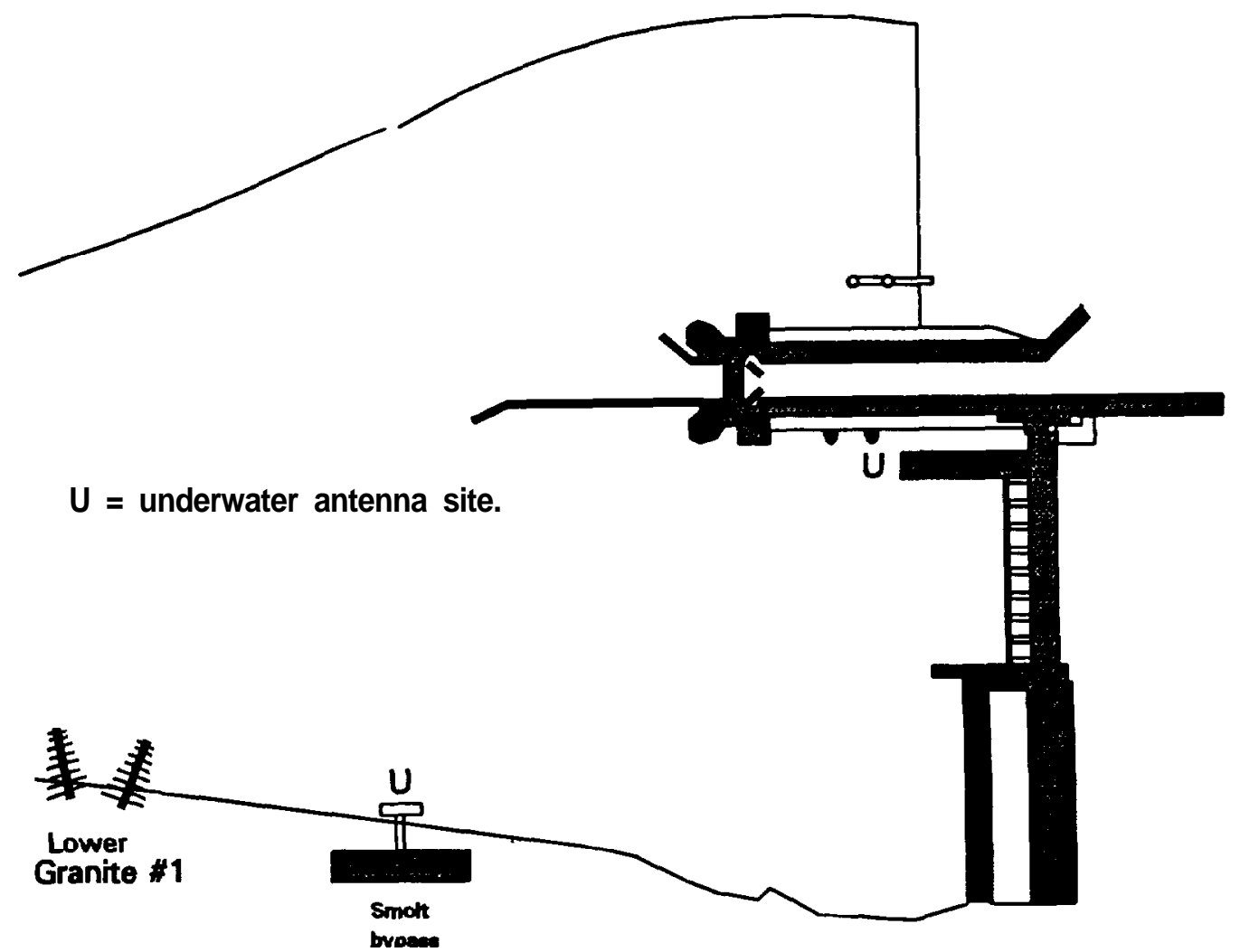

Figure 3. Drawing of fixed receiving sites at Lower Granite Dam in 1992. 
Lower Granite Dam and consisted of two nine-element Yagi antennas. Lower Granite \#l could detect any fish moving past its position in less than $12 \mathrm{~m}$ of water.

Additional fixed stations were located at the smolt bypass and near the north shore fish ladder entrance. Underwater antennas were used at these sites to allow the monitoring of small areas. One receiver was available to monitor both sites and was alternately changed on a weekly basis.

Objective 3 .

The movements of northern squawfish were monitored in numerous ways starting with their release. Distributional data was acquired by taking simultaneous bearings on squawfish positions from pairs of predetermined triangulation stations (Figure 4). The presence of fish with transmitters was recorded from all stations three times a week. Triangulations were conducted during four periods of the day (morning 4:30 am- 7:30 am-, midday 11:00 am - 2:00 $\mathrm{pm}$, evening 6:00 pm - 9:00 pm, and night 11:00 pm - 2:00 am). Sampling was scheduled to ensure equal effort at all stations during each period. The area sampled by triangulation was divided into nine cells for later statistical analysis (Figure 5). Each triangulation fix fell into one of the nine cells. Cell means were calculated by dividing the total number of fish found in a cell during the field season by the number of times a cell was sampled. 


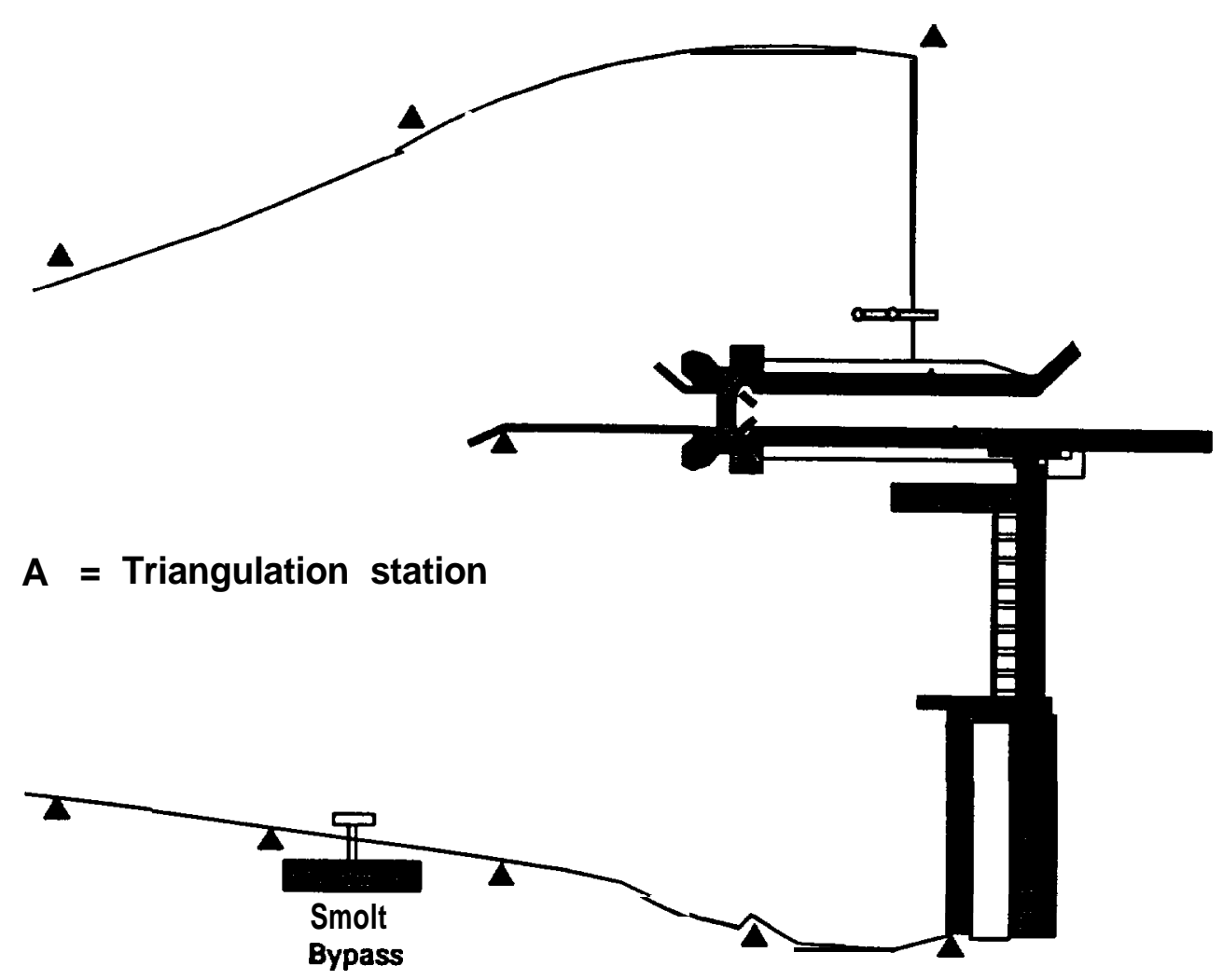

Figure 4. Triangulation stations used to determine northern squawfish positions in the Lower Granite Dam tailrace in 1992.

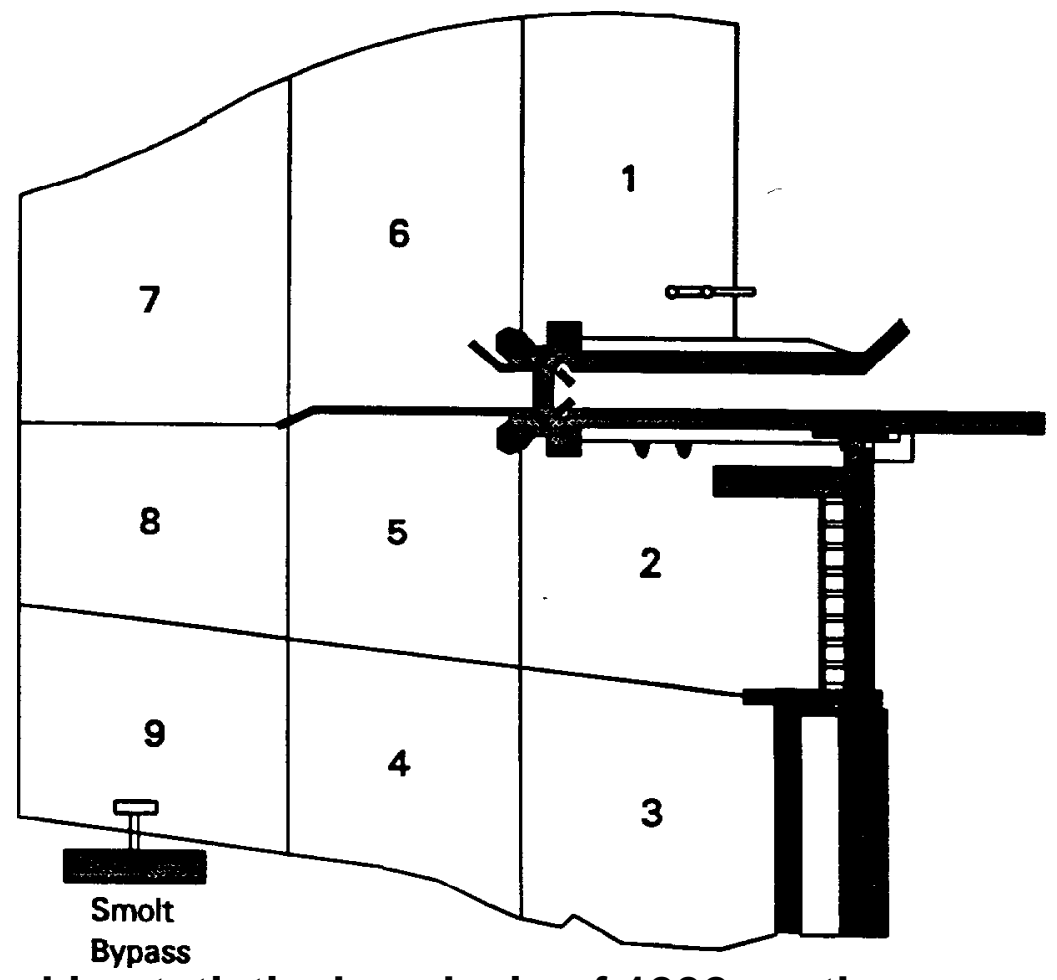

Figure 5. Cells used in statistical analysis of 1992 northern squawfish distributional data in the Lower Granite Dam tailrace. 
On a weekly basis, a boat equipped with a six-element Yagi antenna was used to locate sguawfish which had moved away from Lower Granite Dam. An effort was made to cover the entire Iittle Goose pool during these searches. On two occasions, the boat was also used to continuously monitor the position of several northern sguawfish near the dam. Each fish was relocated on an hourly basis over a 16 hour period.

Whenever the boat was used, a fish was located by following the line of maximum signal strength. As the distance to the fish decreased, the radio receiver gain was decreased. This diminished the antennas' reception field and increased its directionality. This procedure was followed until the boat was directly above a fish.

Our efforts were coordinated with the Native American fishery and the sguawfish'bounty program. By offering a \$5 reward for all returned transmitters, we were able to utilize bounty program check stations to obtain information on recaptured fish. Check station workers collected the returned transmitters and information on when and where a sguawfish was recaptured.

\section{Results}

The first group of sguawfish with transmitters was released in late April, prior to the peak in numbers of smolts passing Lower Granite Dam (Figure 6). A total of 77 northern sguawfish were outfitted with transmitters and 


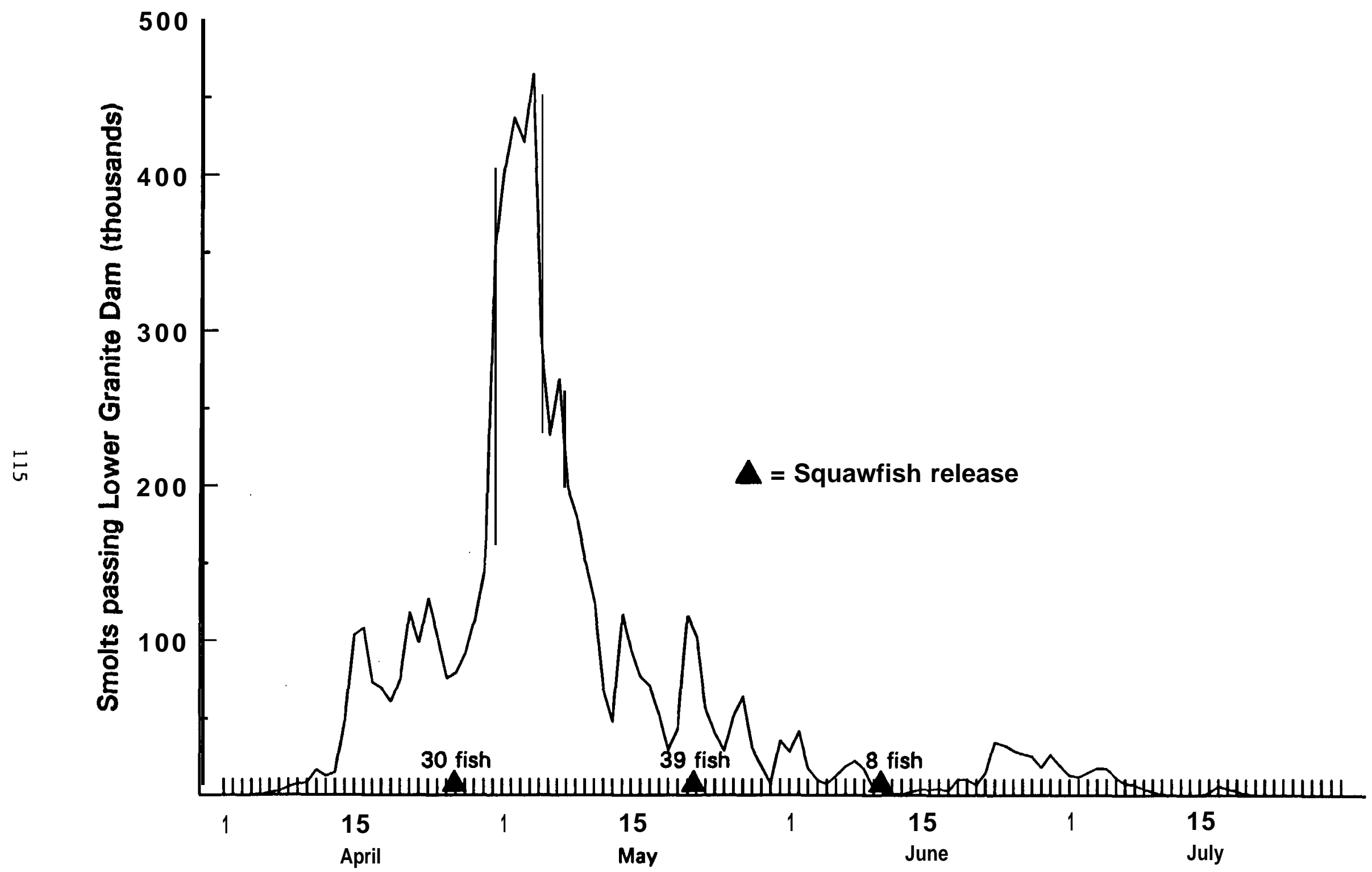

Figure 6. Comparison of total smolts passing Lower Granite Dam and the releasedates of squawfish with transmitters in 1992. 
released in the Lower Granite Dam tailrace during the 1992 field season. Thirty northern sguawfish were implanted with transmitters on April 25, thirty-nine on May 20, and eight on June 11. All fish were captured by electrofishing immediately below Lower Granite Dam and were released at their original capture site after the surgery was complete. Post-operative mortality ranged between 1.3 and $2.6 \%$. One death is confirmed and another is probable. The actual post-operative mortality rate is probably higher, but it is impossible to estimate due to premature transmitter failure.

In the weeks after the releases, it became apparent that only a fraction of the fish were being relocated. The possibility of faulty transmitters was substantiated when sguawfish began turning up at bounty check stations with nonfunctional transmitters. Over the course-of the summer, 9 of 12 (75\%) transmitters returned through the sport and Indian fisheries were nonfunctional. Contact was lost with 33 of 77 (43\%) transmitters within two weeks and 66 of 77 (86\%) within two months (Appendix A). These figures assume that movement out of the study area was minimal. To verify this, a boat was used to search for sguawfish above Lower Granite Dam and below Little Goose Dam. No fish were found during either of these efforts. The failure rate would account for our inability to locate the majority of fish still at large.

Despite the transmitter problems, some data was collected during the time the transmitters were working. 
Data collected from triangulation stations was segregated by day-period (Figure 7) and a G-test (Sokal and Rohlf 1981) was used to test differences between all possible pairwise comparisons of distributions. Two comparisons were found significant, midday versus night, and morning versus midday (Table 1) .

Table 1. G-test statistics for all possible pairwise comparisons between day-period distributions of northern sguawfish at Lower Granite Dam in 1992. $i^{*}=p<.05$ )

\begin{tabular}{lll}
\hline & Comparison & G - statistic \\
\hline 1. & Night versus evening & 2.39 \\
2. & Evening versus morning & 1.10 \\
3. & Night versus morning & 5.85 \\
4. & Evening versus midday & 5.53 \\
5. & Night versus midday & $\mathbf{7 . 6 4}^{*}$ \\
6. & Morning versus midday & $6.49^{*}$ \\
\hline
\end{tabular}

Sample sizes were insufficient to allow comparisons of cell means within a day-period. Therefore, data for all day-periods were pooled and Scheffe's S test (Kirk 1982) was used to compare the mean of one cell with the remaining cell means. Only cell 2 contained significantly more sguawfish than the remaining cells (Figure 8 ).

Continual monitoring of individual sguawfish was conducted on July 8 and 15. These movement patterns are displayed in Figures $9-12$. Individual fish exhibited individual movement patterns; some fish remained stationary for extended periods while others moved on a regular basis. The longest movements generally occurred during crepuscular periods. 


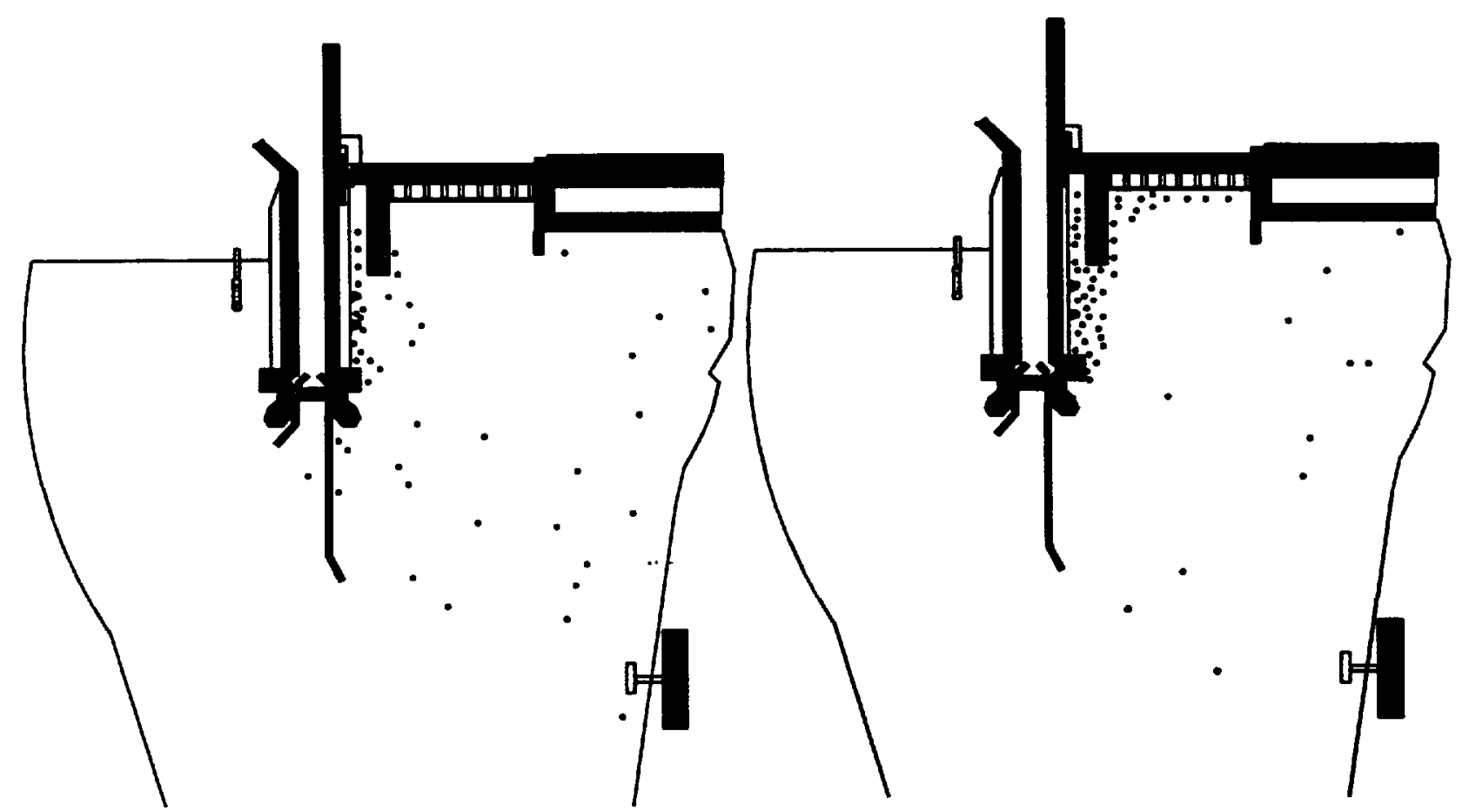

Morning ( $n=44)$

Midday ( $\mathrm{n}=56$ )

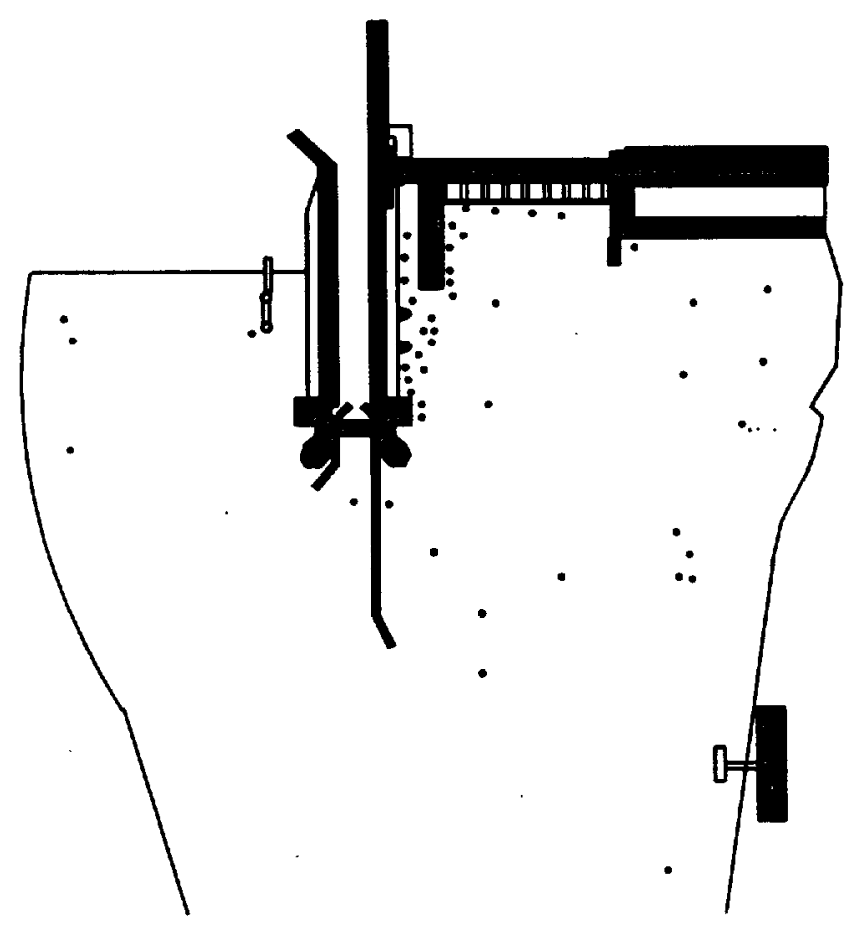

Evening ( $n=48)$

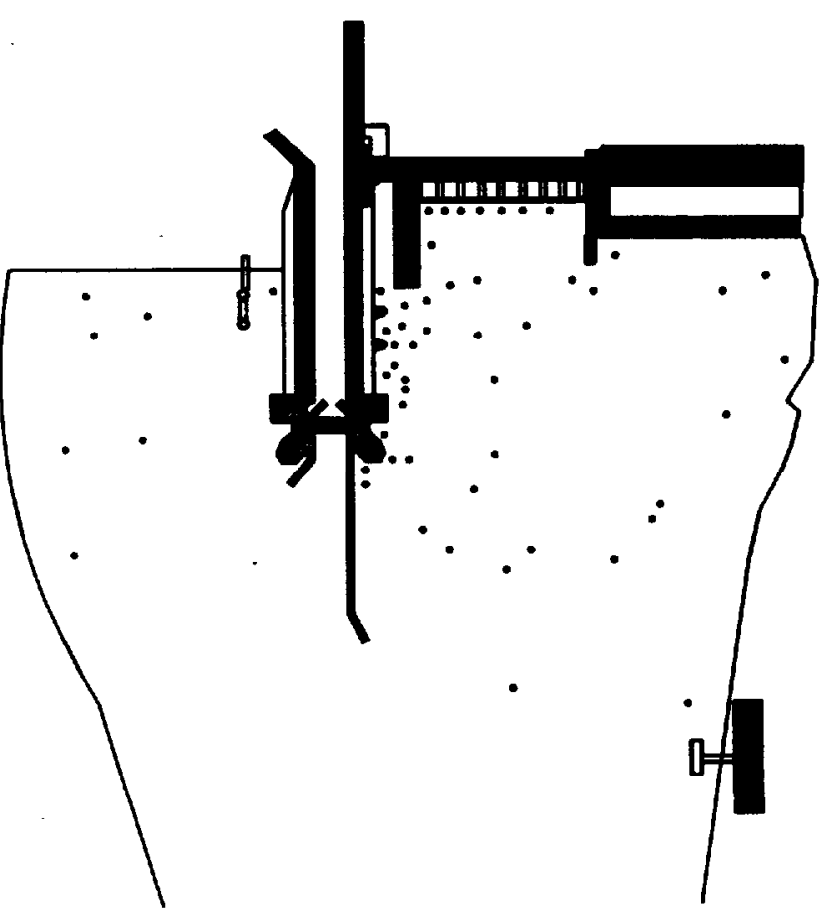

Night $(n=56)$

Figure 7. Distributions of northern squawfish at Lower Granite Dam between May 26 and July 7, 1992 during four periods of the day. 


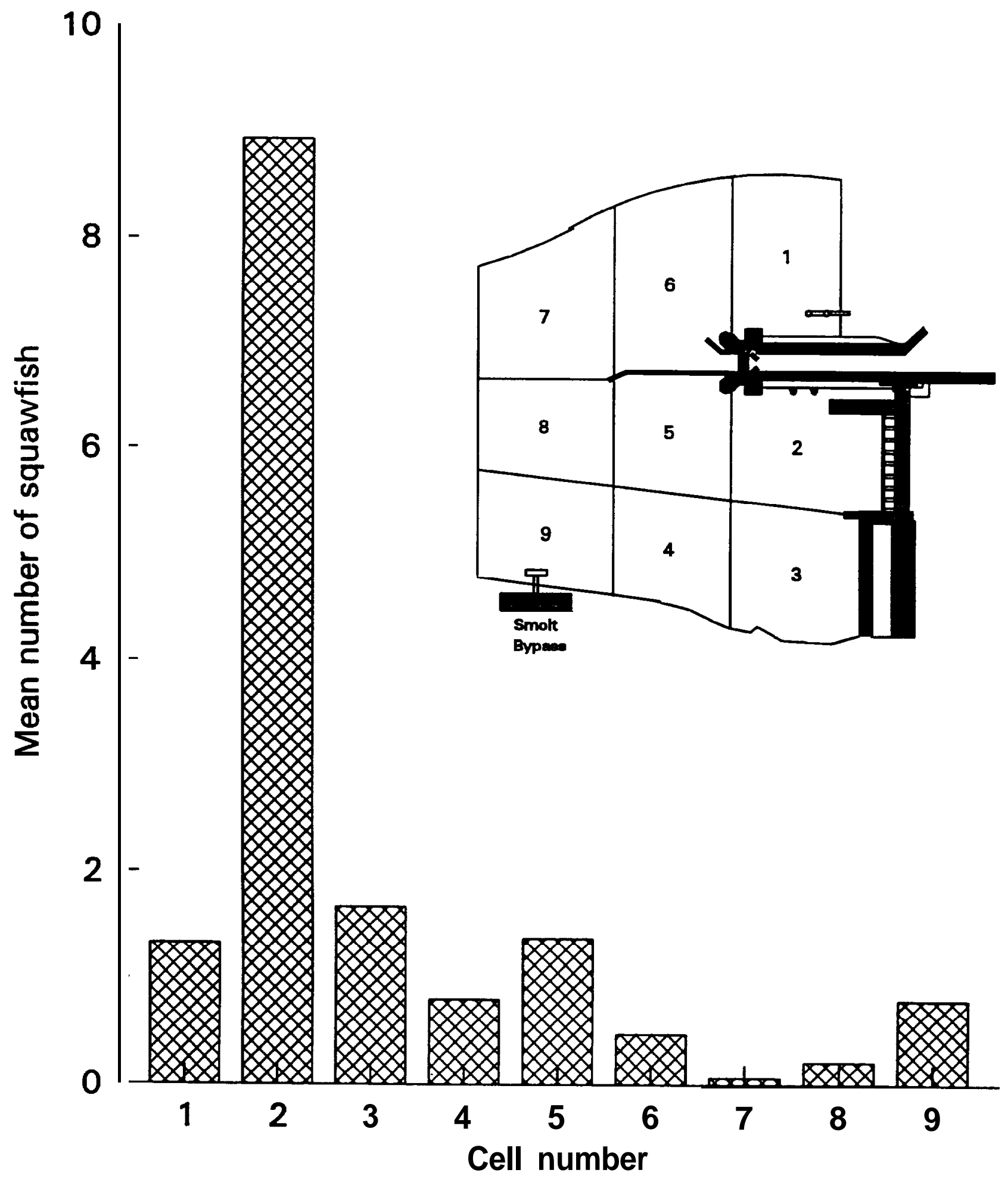

Figure 8. Mean numbers of squawfish per cell at Lower Granite Dam in 1992. 


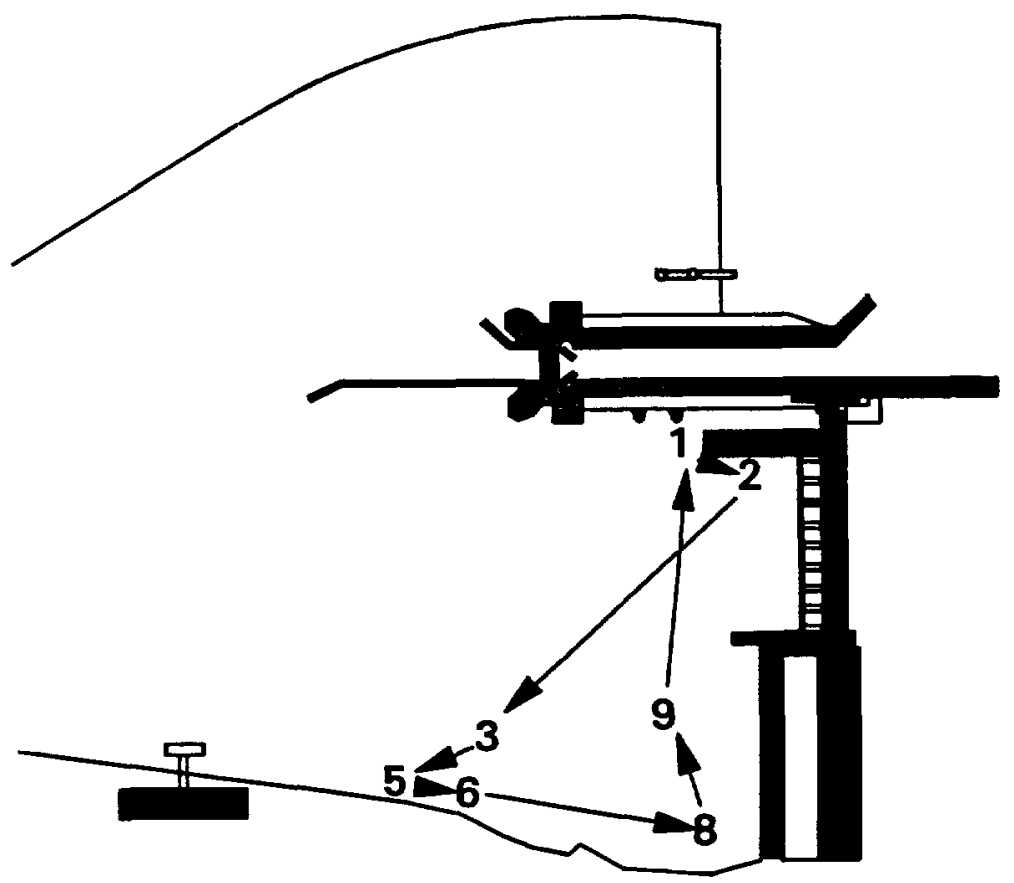

Location times.

1) 8:05 pm.

2) $9: 10 \mathrm{pm}$.

3) $10: 30 \mathrm{pm}$.

4) $11: 37 \mathrm{pm}$ - unchanged.

5) $12: 40 \mathrm{am}$.

6) $2: 18 \mathrm{am}$.

7) 3:30 am - unchanged.

8) $5: 14 \mathrm{am}$.

9) 6:40 am.

10) $8: 20$ am - postition 1 .

11) 10:06 am - unchanged.

Figure 9. Movements of northern squawfish number 23 - 14 atower Granite Dam on July 15, 1992.

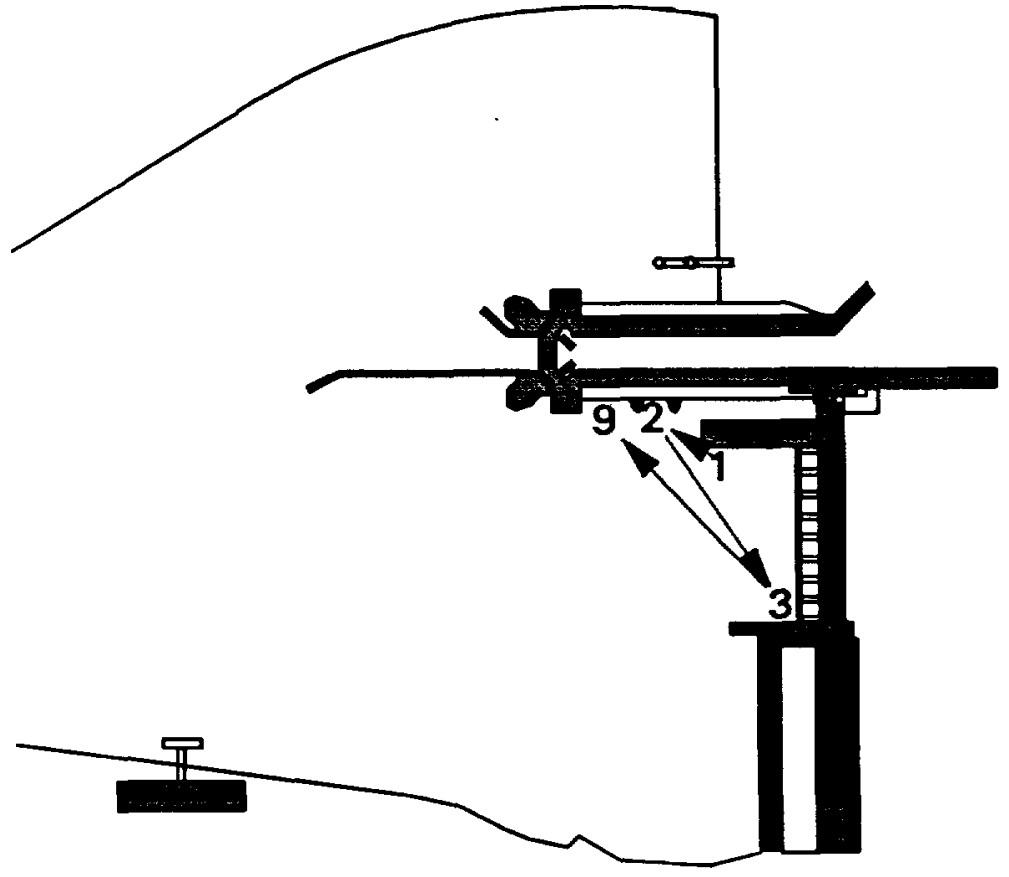

Location times.

1) 7:40 pm.

2) $8: 50 \mathrm{pm}$.

3) $10: 15 \mathrm{pm}$.

4) $11: 27 \mathrm{pm}$ - unchanged.

5) 12:40 am - unchanged.

6) 2:00 am - unchanged.

7) 3:18 am - unchanged.

8) 4:30 am - unchanged.

9) 6:00 am.

10) $7: 24$ am - unchanged.

11) $8: 25$ am - unchanged.

12) 10:00 am - unchanged.

Figure 10. Movements of northern squawfish number 24-21 at Lower Granite Dam on July 15, 1992. 


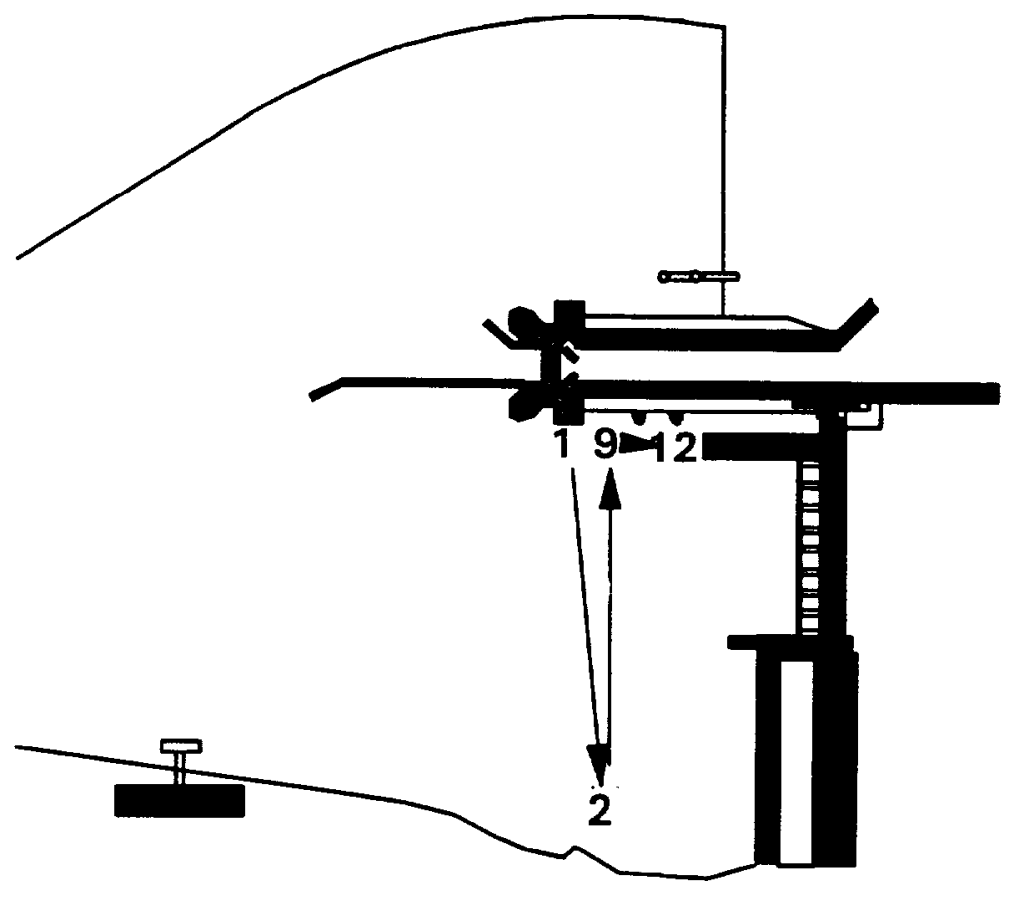

Location times.

1) $8: 30 \mathrm{pm}$.

2) $9: 40 \mathrm{pm}$.

3) $10: 36 \mathrm{pm}$ - unchanged.

4) $11: 45$ pm - unchanged.

5) 1:00 am - unchanged.

6) 2:00 am - unchanged.

7) 3:26 am - unchanged.

8) 4:45 am -unchanged.

9) $6: 30 \mathrm{am}$.

10) 7:24 am - unchanged.

11) $8: 25$ am - unchanged.

12) $10: 06 \mathrm{am}$.

Figure 11. Movements of northern squawfish number 27 - 21 at Lower Granite Dam on July 15, 1992.

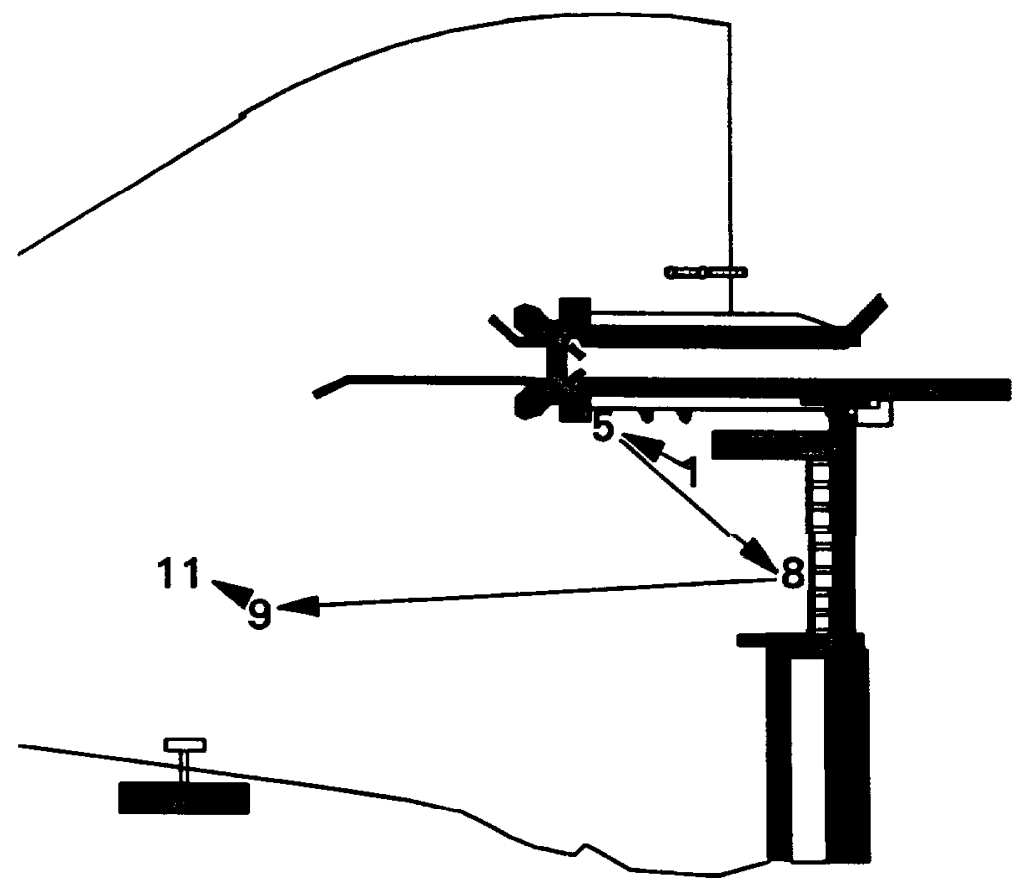

Location times.

1) 7:54 pm.

2) 8:57 pm - unchanged.

3) 10:05 pm - unchanged.

4) $11: 21 \mathrm{pm}$ - unchanged.

5) $12: 32 \mathrm{am}$.

6) $1: 53$ am - unchanged.

7) 3:11 am - unchanged.

8) 4:30 am.

9) $6: 20 \mathrm{am}$.

10) $7: 37$ am - unchanged.

11) $8: 38 \mathrm{am}$.

12) 10:27 am - unchanged.

Figure 12. Movements of northern squawfish number 24 - 13 at Lower Granite Dam on July 15, 1992. 
Squawfish were found within Little Goose Reservoir as far downriver as Central Ferry (Figure 13). No squawfish were relocated between Central Ferry and Little Goose Dam. It is unclear whether squawfish simply were not using the lower reservoir or whether sampling there was ineffective due to increasing reservoir width and depth. One squawfish with a nonfunctional tag was recaptured below Little Goose Dam in the bounty program.

Movement through the fish ladder at Lower Granite Dam appeared to be minimal. Fish counters observed two transmitter equipped squawfish move past the counting window, but NMFS personnel reported no such fish in their trap. Therefore, it is believed that these fish went back down the ladder.

\section{Discussion}

Based on data from squawfish released in late April and May, the majority were found in a small portion of cell 2 during the second half of the smolt migration. No data is available on the distribution of smolts downstream from Lower Granite Dam, but cell 2 would not be expected to contain high smolt concentrations relative to the turbine discharge because there is no source of smolts in the immediate area. Based on daily movements of squawfish, the fish seem to move from cell 2 into the turbine discharge when foraging and then return when satiated. The slackwater environment of cell 2 is used mainly as a loafing area 


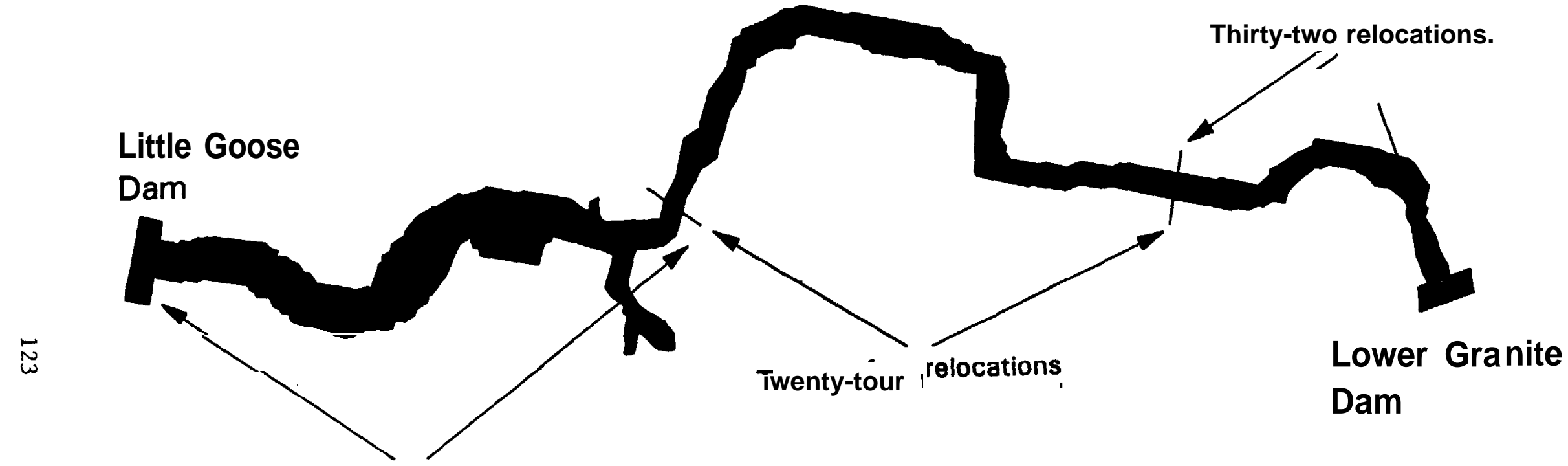

Zero relocations.

Figure 13. Relocations of northern squawfish within Little Goose Reservoir between June 5 and August 6, 1992. 
between foraging forays. Why squawfish move primarily under low light conditions is unknown, perhaps it is a consequence of light sensitivity, a nocturnal peak in smolt migration, or increased predatory efficiency.

Regardless of the reasons for their distribution, few squawfish were found near the smolt bypass in 1992. Few smolts were bypassed back to the river and it is unknown whether squawfish would have used this area more had smolts been bypassed on a regular basis.

First year data and conclusions should be viewed as preliminary because data was collected on a handful of fish with transmitters that worked for more than two months and the majority of others that worked for a few weeks. Additionally, flow conditions at Lower Granite Dam were homogeneous, with no spill and few smolts bypassed back to the river.

In conclusion, we feel that the specific goals of the first sampling season were met, despite premature transmitter failure. A method was developed for properly implanting squawfish with transmitters. Antenna and receiver setups were implemented to gather data on squawfish movements and additional methodologies were developed for using a boat to collect data. Fish were monitored during the smolt migration, both within the reservoir and at the dam. 


\section{Literature Cited}

Bidgood, B. F. 1980. Fish surgical procedure for implantation of radio tags in fish. Alberta Division of Fish and Wildlife. Fisheries Research Report 20. Alberta, Canada

Sokal, R. R., and F. J. Rohlf. 1981. Biometry. W. H. Freeman and Company.

Kirk, R. E. 1982. Experimental design, 2nd ed. Brooks/Cole Publishing Company, Pacific Grove, CA. 
Appendix A

\begin{tabular}{|c|c|c|c|c|c|c|c|}
\hline Fish & $\begin{array}{c}\text { Total } \\
\text { Length }(\mathrm{cm})\end{array}$ & $\begin{array}{l}\text { Release } \\
\text { Date }\end{array}$ & $\begin{array}{l}\text { Release } \\
\text { Kilometer }\end{array}$ & $\begin{array}{c}\text { Last } \\
\text { Record } \\
\text { Date }\end{array}$ & $\begin{array}{c}\text { Last } \\
\text { Record } \\
\text { Kilometer }\end{array}$ & $\begin{array}{c}\text { Total } \\
\text { Days } \\
\text { Contacted }\end{array}$ & $\begin{array}{c}\text { Distance } \\
\text { Travelled } \\
(\mathrm{km})\end{array}$ \\
\hline $25-16$ & 37.3 & 26-Apr-92 & 172.5 & 27-Apr-92 & 172.5 & 1.0 & 0.0 \\
\hline $25-17$ & 55.0 & 26-Apr-92 & 172.5 & 26-Apr-92 & 172.5 & 0.0 & 0.0 \\
\hline $25-18$ & 39.8 & 26-Apr-92 & 172.0 & 27-Apr-92 & 170.9 & 1.0 & 1.1 \\
\hline $25-21$ & 42.0 & 26-Apr-92 & 172.5 & 26-Apr-92 & 170.9 & 0.0 & 1.6 \\
\hline $25-22$ & 40.2 & 26-Apr-92 & 172. 5 & 06-Jul-92 & 163.5 & 71.0 & 9.0 \\
\hline $25-24$ & 41.2 & 26-Apr-92 & 172.5 & 05-Jun-92 & 172.0 & 40.0 & 0.5 \\
\hline $26-16$ & 38.5 & 26-Apr-92 & 172.5 & 02-May-92 & 170.9 & 6.0 & 1.6 \\
\hline $26-17$ & 41.3 & 26-Apr-92 & 172.5 & 07-Jun-92 & 170.9 & 42.0 & 1.6 \\
\hline $26-19$ & 37.1 & 26-Apr-92 & 172.5 & 19-Jun-92 & 170.1 & 54.0 & 2.4 \\
\hline $26-20$ & 37.9 & 26-Apr-92 & 171.1 & 05-Jun-92 & 139.6 & 40.0 & 31.5 \\
\hline $26-21$ & 35.4 & 26-Apr-92 & 172.5 & 27-Apr-92 & 170.9 & 1.0 & 1.6 \\
\hline $26-23$ & 48.7 & 26-Apr-92 & 172.5 & 20-Jun-92 & 172.0 & 55.0 & 0.5 \\
\hline $27-17$ & 40.3 & 26-Apr-92 & 172.5 & 11 -Jun-92 & 170.9 & 46.0 & 1.6 \\
\hline 27-18 & 37.4 & 26-Apr-92 & 172.5 & 26-Apr-92 & 172.5 & 0.0 & 0.0 \\
\hline $27-20$ & 37.7 & 26-Apr-92 & 172.5 & 04-Jun-92 & 172.0 & 39.0 & 0.5 \\
\hline $27-21$ & 47.9 & 26-Apr-92 & 172.5 & 14-Jul-92 & 172.5 & 79.0 & 0.0 \\
\hline $27-23$ & 38.8 & 26-Apr-92 & 172.5 & 29-Apr-92 & 170.1 & 3.0 & 2.4 \\
\hline 27-24 & 44.9 & 26-Apr-92 & 172.5 & 02-Мау-92 & 172.5 & 6.0 & 0.0 \\
\hline $28-16$ & 51.6 & 26-Apr-92 & 172.5 & 14-Jul-92 & 172.0 & 79.0 & 0.5 \\
\hline $28-18$ & 36.8 & 26-Apr-92 & $171: 7$ & 11 -Jun-92 & 172.2 & 46.0 & -0.5 \\
\hline 28-21 & 39.1 & 26-Apr-92 & 172.5 & 30-May-92 & 170.9 & 34.0 & 1.6 \\
\hline $28-22$ & 42.1 & 26-Apr-92 & 171.1 & 28-May-92 & 172.5 & 32.0 & -1.4 \\
\hline $28-23$ & 39.1 & 26-Apr-92 & 172.5 & 03-May-92 & 172.2 & 7.0 & 0.3 \\
\hline $28-24$ & 45.1 & 26-Apr-92 & 172.5 & 09-Jul-92 & 172.2 & 74.0 & 0.3 \\
\hline $29-15$ & 44.3 & 26-Apr-92 & 172.5 & 18-May-92 & 172.2 & 22.0 & 0.3 \\
\hline $29-18$ & 45.3 & 26-Apr-92 & 172.5 & 08-May-92 & 170.9 & 12.0 & 1.6 \\
\hline 29-21 & 36.8 & 26-Apr-92 & 171.7 & 26-Apr-92 & 171.7 & 0.0 & 0.0 \\
\hline $29-22$ & 41.5 & 26-Apr-92 & 171.1 & 15-Sep-92 & 171.7 & 142.0 & -0.6 \\
\hline $29-23$ & 41.7 & 26-Apr-92 & 171.1 & 03-May-92 & 172.2 & 7.0 & -1.1 \\
\hline \multirow[t]{2}{*}{$29-24$} & 45.6 & 26-Apr-92 & 172.5 & 06-Jul-92 & 163.0 & 71.0 & 9.5 \\
\hline & & & & Release \#1 & Average & 33.7 & 2.2 \\
\hline $24 \cdot 2$ & 52.8 & 21 -May-92 & 172.5 & 29-May-92 & 172.2 & 8.0 & 0.3 \\
\hline $21-9$ & 36.1 & 21 -May-92 & 172.5 & $01-J u l-92$ & 152.1 & 41.0 & 20.4 \\
\hline 21-11 & 37.7 & 21 -May-92 & 172.5 & 29-May-92 & 172.5 & 8.0 & 0.0 \\
\hline $23-12$ & 41.7 & 21 -May-92 & 172.5 & 30-Jun-92 & 155.0 & 40.0 & 17.5 \\
\hline $21-13$ & 45.7 & 21 -May-92 & 172.5 & 03-Jun-92 & 172.2 & 13.0 & 0.3 \\
\hline $21-15$ & 42.6 & 21 -May-92 & 172.5 & 10-Jul-92 & 144.6 & 50.0 & 27.9 \\
\hline 21-19 & 40.3 & 21 -May-92 & 172.5 & 21 -May-92 & 172.5 & 0.0 & 0.0 \\
\hline $21-24$ & 39.6 & 21 -May-92 & 172.5. & 27-May-92 & 172.2 & 6.0 & 0.3 \\
\hline$-22-2$ & 43.5 & 21 -May-92 & 172.5 & 21 -May-92 & 172.5 & 0.0 & 0.0 \\
\hline $22=9$ & 55.1 & 21 -May-92 & 172.5 & 01 -Jun-92 & 170.9 & 11.0 & 1.6 \\
\hline $2 \cdot 12$ & 41.1 & 21 -May-92 & 172.5 & 11 -Jun-92 & 172.0 & 21.0 & 0.5 \\
\hline $22-13$ & 51.5 & 21 -May-92 & 172.5 & 23-Jun-92 & 161.1 & 33.0 & 11.4 \\
\hline
\end{tabular}




\begin{tabular}{|c|c|c|c|c|c|c|c|}
\hline $22-14$ & 36.9 & 21 -May-92 & 172.5 & 10-Jul-92 & 146.8 & 50.0 & 25.7 \\
\hline $22-16$ & 38.2 & 21 -May-92 & 172.5 & 1 O-Jut-92 & 152.6 & 50.0 & 19.9 \\
\hline $22-20$ & 38.5 & 21 -May-92 & 172.5 & 06-Aug-92 & 166.9 & 77.0 & 5.6 \\
\hline $22-24$ & 44.3 & 21 -May-92 & 172.5 & 07-Jun-92 & 170.9 & 17.0 & 1.6 \\
\hline $23-2$ & 38.4 & 21 -May-92 & 172.5 & 27-May-92 & 172.5 & 6.0 & 0.0 \\
\hline 23-11 & 36.3 & 21 -May-92 & 172.5 & 24-Jun-92 & 138.6 & 34.0 & 33.9 \\
\hline $23-14$ & 41.5 & 21 -May-92 & 172.5 & 14-Jul-92 & 172.5 & 54.0 & 0.0 \\
\hline 23-17 & 40.0 & 21-May-92 & 172.5 & 03-Jun-92 & 172.5 & 13.0 & 0.0 \\
\hline 23-19 & 38.4 & 21 -May-92 & 172.5 & 21 -May-92 & 172.5 & 0.0 & 0.0 \\
\hline $\begin{array}{l}23-22 \\
23-25\end{array}$ & $\begin{array}{l}54.0 \\
42.7\end{array}$ & $\begin{array}{l}21-\text { May-92 } \\
21 \text {-May-92 }\end{array}$ & $\begin{array}{l}172.5 \\
172.5\end{array}$ & $\begin{array}{l}\text { 09-Jul-92 } \\
14-J u l-92\end{array}$ & $\begin{array}{l}168.5 \\
162.1\end{array}$ & $\begin{array}{l}49.0 \\
54.0\end{array}$ & $\begin{array}{r}4.0 \\
10.4\end{array}$ \\
\hline $24-9$ & 43.6 & 21 -May-92 & 172.5 & 08-Jun-92 & 172.5 & 18.0 & 0.0 \\
\hline 24-11 & 38.7 & 21 -May-92 & 172.5 & 29-May-92 & 172.5 & 8.0 & 0.0 \\
\hline 24-12 & 43.5 & 21 -May-92 & 172.5 & 05-Jul-92 & 170.9 & 45.0 & 1.6 \\
\hline 24-13 & 37.2 & 21 -May-92 & 172.5 & 06-Aug-92 & 172.0 & 77.0 & 0.5 \\
\hline $24-18$ & 46.3 & 21 -May-92 & 172.5 & 21 -May-92 & 172.5 & 0.0 & 0.0 \\
\hline $24-20$ & 38.4 & 21 -May-92 & 172.5 & 27-May-92 & 161.3 & 6.0 & 11.2 \\
\hline 24-21 & 47.5 & 21 -May-92 & 172.5 & 14-Jul-92 & 172.0 & 54.0 & 0.5 \\
\hline $25-1$ & 36.1 & 21 -May-92 & 172.5 & 27-May-92 & 172.0 & 6.0 & 0.5 \\
\hline $25-5$ & 39.9 & 21-May-92 & 172.5 & 29-May-92 & 172.0 & 8.0 & 0.5 \\
\hline $26-10$ & 37.7 & 21-May-92 & 172.5 & 25-Jun-92 & 172.0 & 35.0 & 0.5 \\
\hline $27 \cdot 3$ & 53.2 & 21 -May-92 & 172.5 & 01 -Jul-92 & 172.0 & 41.0 & 0.5 \\
\hline $27-8$ & 36.3 & 21 -May-92 & 172.5 & 28-May-92 & 170.9 & 7.0 & 1.6 \\
\hline $28-6$ & 52.2 & 21 -May-92 & 172.5 & 26-May-92 & 172.2 & 5.0 & 0.3 \\
\hline $28-7$ & 41.7 & 21 -May-92 & 172.5 & 07-Jun-92 & 172.5 & 17.0 & 0.0 \\
\hline $29-7$ & 47.2 & 21 -May-92 & 172.5 & 19-Jun-92 & 172.5 & 29.0 & 0.0 \\
\hline \multirow[t]{2}{*}{$29-8$} & 41.0 & 21 -May-92 & 172.5 & 1 0-Aug-92 & 172.2 & 81.0 & 0.3 \\
\hline & & & & Release $\# 2$ & Average & 27.5 & 5.1 \\
\hline $21-1$ & 37.2 & 11 -Jun-92 & 165.9 & 07-Aug-92 & 137.2 & 57.0 & 28.7 \\
\hline $23-3$ & 40.3 & 11 -Jun-92 & 165.9 & 18-Jun-92 & 141.5 & 7.0 & 24.4 \\
\hline $24 \cdot 7$ & 36.7 & 11 -Jun-92 & 165.9 & $10-J u l-92$ & 154.0 & 29.0 & 11.9 \\
\hline $26-3$ & 39.0 & 11 -Jun-92 & 165.9 & 11 -Jun-92 & 165.9 & 0.0 & 0.0 \\
\hline $26 \cdot 7$ & 41.6 & 11-Jun-92 & 165.9 & 17-Jun-92 & 151.0 & 6.0 & 14.9 \\
\hline 27-15 & 36.3 & 11 -Jun-92 & 172.0 & 01 -Jul-92 & 148.0 & 20.0 & 24.0 \\
\hline $28-12$ & 36.2 & 11 -Jun-92 & 165.9 & 30-Jun-92 & 159.0 & 19.0 & 6.9 \\
\hline \multirow[t]{3}{*}{$29 \cdot 3$} & 48.6 & 11 -Jun-92 & 172.0 & 17-Jun-92 & 155.8 & 6.0 & 16.2 \\
\hline & & & & Release \#3 & Average & 18.0 & 15.9 \\
\hline & & & & Grand & Average & 29.0 & 5.1 \\
\hline
\end{tabular}

